\title{
Information Asymmetry and the Timing of Capital Issuance: An International Examination
}

\author{
April M. Knill* and Bong Soo Lee*
}

\begin{abstract}
Using issuance data across 50 countries from 1996 through 2009, we examine the role of information asymmetry in market timing globally. We utilize a model that takes into account the possible feedback of security issues to past market returns allowing us to ascertain whether timing of capital issuance around the world is based on information asymmetry. We find evidence of both market timing and pseudo market timing. The evidence for market timing is significantly stronger in international sub-samples with greater levels of information asymmetry when capital issuance is measured by equity share. The evidence for pseudo market timing is consistent across sub-samples when capital issuance is measured by changes in equity issuance. These results suggest that information asymmetry in a market plays an important role in the ability of managers to time capital issuance and that counter to the implications of extant literature, market timing and pseudo market timing are not mutually exclusive, i.e., existence of one does not nullify the other.
\end{abstract}

JEL classification: C53, G14, G15, G32,

Key words: equity issues, market timing, information asymmetry, international evidence

\footnotetext{
- College of Business, The Florida State University, Rovetta Business Building, Tallahassee, FL 32306, aknill@ cob.fsu.edu, (tel) 850-644-2047, (fax) 850-644-4225

- College of Business, The Florida State University, 251 Rovetta Business Building, Tallahassee, FL 32306, blee2@cob.fsu.edu, (tel) 850-644-4713, (fax) 850-644-4225
} 


\title{
Information Asymmetry and the Timing of Capital Issuance: An International Examination
}

\begin{abstract}
Using issuance data across 50 countries from 1996 through 2009, we examine the role of information asymmetry in market timing globally. We utilize a model that takes into account the possible feedback of security issues to past market returns allowing us to ascertain whether timing of capital issuance around the world is based on information asymmetry. We find evidence of both market timing and pseudo market timing. The evidence for market timing is significantly stronger in international sub-samples with greater levels of information asymmetry when capital issuance is measured by equity share. The evidence for pseudo market timing is consistent across sub-samples when capital issuance is measured by changes in equity issuance. These results suggest that information asymmetry in a market plays an important role in the ability of managers to time capital issuance and that counter to the implications of extant literature, market timing and pseudo market timing are not mutually exclusive, i.e., existence of one does not nullify the other.
\end{abstract}

JEL classification: C53, G14, G15, G32,

Key words: equity issues, market timing, information asymmetry, international evidence 
Market timing and pseudo market timing theories differ fundamentally with respect to whether market efficiency holds or not ${ }^{1}$ and thus the literature implicitly assumes that market timing and pseudo market timing are mutually exclusive ideas; proof of the existence of one nullifies the existence of the other. Given the important role that information asymmetry plays in market timing, however, it makes sense that the level of information asymmetry in a market would affect the likelihood that market timing could occur. Depending on the relative information asymmetry in a given nation, managers may not be able to exploit their superior knowledge. Conversely, in pseudo market timing, which uses a more backward-looking approach, information asymmetry may not play an important role. Examining the U.S. only, as many studies on market timing and pseudo market timing have done in the past, conceals the role of information asymmetry in the timing of capital issuance. As such, the extant literature has heretofore found evidence of one theory or the other, suggesting that they are mutually exclusive. We posit that using a cross-section (i.e., international sample) is a more appropriate sample to examine the timing of capital issuance in that it allows for diversity in information asymmetry, which in turn allows for evidence of both market timing and pseudo market timing. We further posit that the patterns of this evidence may be explained using information asymmetry.

Henderson et al. (2006) take a first step in examining the timing of capital-raising in an international setting, finding evidence of both market timing and pseudo market timing in an international study. They note that "estimates vary somewhat across regions" (p. 80). Indeed this is the case. Using equity share as the determinant, only roughly half of the sub-samples analyzed show evidence of market timing and/or pseudo market timing. As the intent of Henderson et al. (2006) is a preliminary examination of the world

\footnotetext{
${ }^{1}$ Some studies find little evidence that IPOs and SEOs underperform the market on a risk-adjusted basis (e.g., Brav et al., 2000; Eckbo et al., 2000; Mitchell and Stafford, 2000; Li and Zhao, 2003; and Butler et al., 2005). Gao et al. (2011) show that U.S. IPOs from 1980-2009 underperform size- and book-to-market benchmarks when the pre-issue annual sales are less than $\$ 50 \mathrm{M}$ (\$2009) by $\mathrm{x} \%$, but have insignificant positive abnormal performance when in the three years after issuing pre-issue sales are above \$50M. Chan et al. (2008) also report conditional underperformance. Butler et al. (2005) argue that the negative association between equity issues and future aggregate stock returns is spurious. They show that the negative relation is primarily driven by the strong positive correlation between market prices and the equity share surrounding the two structural breaks in U.S. economic activities -- the Great Depression (1929-1931) and the oil crisis (1973-1974) periods -- and there is no out-of- sample predictive power in the equity share variable.
} 
market for raising capital, they do not attempt to examine why some evidence of both competing hypotheses is found or why that evidence varies across nations. Our paper extends Henderson et al. (2006) by exploring these issues. Combining the implications from the market timing, pseudo market timing, and information asymmetry in capital issuance literatures, we explain the patterns in market timing and pseudo market timing across 50 countries over the period 1996-2009. Specifically, we attempt to explain patterns in the evidence of market timing and pseudo market timing as well as capital types (i.e., the equity share, equity and debt).

Using an econometric model designed to carefully control for information asymmetry, we examine the role of information asymmetry in the timing of capital issuance. We examine directly the role of information asymmetry by ascertaining whether there is evidence of Granger causality in informationbased sub-samples. Based on such papers as Miller et al. (2008) and Anderson et al. (2009) who discuss differences in information asymmetry in groups (country development and shareholder dispersion, respectively), we create sub-samples based on information asymmetry: common law versus civil law countries, strong versus weak investment profile, low versus high earnings management smoothing countries, high versus low auditor presence countries, high versus low number of analysts countries, and high versus low institutional investors countries. This allows us to better identify what environments foster market timing (i.e., issuing equity before downturns in the market) and pseudo market timing (i.e., issuing after upturns in the market). ${ }^{2}$

The breadth and depth of our data arguably avoids the small sample bias discussed in prior literature. Examining markets across 50 countries affords us sufficient heterogeneity to ascertain whether it is possible that advocates of both market timing and pseudo market timing are correct. It also allows us to examine what role, if any, information asymmetry (i.e., divergence from market efficiency) plays in market timing around the globe.

\footnotetext{
${ }^{2}$ Given that our international sample covers only fourteen years (1996 through 2009), we don't pursue the issue of whether market timing is real or a fiction being driven by structural breaks or other non-stationarities in the data.
} 
In our analysis, we find greater evidence of market timing of the share of equity in sub-samples with greater information asymmetry (i.e., civil law, weak investment profile, high earnings management smoothing, low auditor and analyst presence as well as low institutional investor importance nations). In support of Baker and Wurgler (2000; 2002), our findings suggest that the variation in the results found by Henderson et al. (2006) are due to information asymmetry. We also find evidence of pseudo market timing of equity issues. This evidence is found in all sub-samples, suggesting that information asymmetry does not play a role in pseudo market timing of equity issues. This is quite intuitive since after return is realized, information asymmetry is resolved. Interestingly, there is a role for information asymmetry in pseudo market timing of debt issues. In particular, there exists evidence of pseudo market timing in subsamples with lower information asymmetry, suggesting that managers use backward-looking consideration for this part of the capital structure.

Comprehensively, we find evidence of both market timing and pseudo market timing of equity issues in sub-samples with greater levels of information asymmetry (i.e., equity share and changes in equity, respectively), suggesting that both hypotheses have merit and that managers can use both forward- and backward-looking strategies to optimize the timing of capital issuance.

The paper closest to ours in the literature is Henderson et al. (2006). Using extensive international data, they find that firms all around the world are more likely to issue equity (debt) prior to periods of low (high) stock (bond) market returns. However, the intent of Henderson et al. (2006) differs considerably from ours. Henderson et al. provide an informative examination of capital issuance in an international setting and find that issuers (pseudo) market time in an international setting. We extend Henderson et al. (2006) by examining the role of information asymmetry in the patterns of both market and pseudo-market timing.

The rest of the paper proceeds as follows. In Section I, we motivate the hypotheses, and in Section II, we discuss the regression equations (i.e., Granger causality) we use in the test of market timing as well as their relation to information asymmetry. In Section III, we describe our data with descriptive statistics and various subsets of different countries. Section IV presents our main empirical results. Section V explores 
the robustness of our results (e.g., excluding Australia, excluding simultaneous international offerings, and looking at only IPOs and follow-on offerings), Section VI offers a final discussion, and finally section VII concludes the paper.

\section{Motivation}

There are two explanations for underperformance by firms following equity offerings: market timing and pseudo market timing. Market timing is a behavioral explanation pioneered by Baker and Wurgler (2000) that suggests that stock prices periodically diverge from fundamental values, and that managers take advantage of overpricing by selling stock or bonds to overly optimistic investors (e.g., Ritter, 1991; Lerner, 1994; Loughran and Ritter, 1995, 2000; Hirshleifer, 2001). ${ }^{3}$ In their U.S.-based study, Flannery and Rangan (2006) state that the market timing hypothesis asserts that managers routinely exploit information asymmetries to benefit current shareholders. ${ }^{4,5}$ The notion that future returns can be predicted from past prices flies in the face of market efficiency, and Schultz (2003) proposes a different explanation for the same phenomenon. Schultz (2003) shows that underperformance by firms following equity offerings is very likely to be observed ex-post in an efficient market and can be explained by a "pseudo" market timing hypothesis (assuming that issuing volume follows a nonstationary process). The premise of the hypothesis is that more firms issue equity at higher stock prices even though the market is efficient and managers have no timing ability.

\footnotetext{
${ }^{3}$ Early studies find that initial public offerings (IPOs) underperform relative to market indices and matching stocks after going public (Ritter, 1991). Other studies find similar underperformance following seasoned equity offerings (SEOs) (e.g., Loughran and Ritter, 1995; Spiess and Affleck-Graves, 1995; Lee, 1997; and Burch et al., 2004). See also Chen and Liang, 2006, who find evidence of market timing ability in hedge funds, especially in bear and volatile markets.

${ }^{4}$ See Sanders and Carpenter (2003) for a discussion of how stock repurchase programs, the opposite of equity issuance, is a function of information asymmetry.

${ }^{5}$ Consistent with this contention, a study by Chang et al. (2010) finds that the companies in a keiretsu (in Japan) cooperate with each other to time equity issues (the specifics of which their investors are not aware) and that this market timing occurs more for keiretsu firms than for standalone firms. Chemmanur and Simonyan (2010) find that firms issue putable convertibles when they have valuable private information; firms without this information issue regular convertibles.
} 
In a related literature, the role of information asymmetry in security issuance was first examined by Myers and Majluf (1984). This seminal paper explained the importance of information in what type of capital firms issue. Papers such as Dierkens (1991), Korajczyk et al. (1991, 1992), Bayless and Chaplinsky (1996), Guo and Mech (2000) and Kennedy et al. (2006) extended this line of research by asking the question whether information asymmetry affects more than just the type of capital. Given that managers know more about the firm than investors, it is theoretically possible for managers to time the issuance of capital to take advantage of stock prices that are overvalued. In this way, managers can minimize their cost of capital, therefore maximizing the value of the firm.

While this research speaks to information asymmetry across time, it is theoretically possible that differences in information asymmetry across markets can also affect a manager's ability to time capital issuance. Given insufficient levels of information asymmetry between managers and investors due to characteristics of a nation (such as legal protection of investors, business stability, and accounting standards such as earnings smoothing, the presence of Big 5 Accounting firms as well as analysts and the importance of institutional investors), managers may not be able to exploit superior knowledge to reap the financial reward of additional proceeds when their equity is over-valued. Market timing, therefore, may only exist in nations where levels of information asymmetry are relatively high. Said formally:

H1: There is greater evidence of market timing (i.e., securities issuance's predictive power of market return) in international sub-samples with greater levels of information asymmetry.

Since ex post, investors have the same information as managers, information asymmetry should not play a role when we test for evidence of pseudo market timing. Specifically, we should find similar evidence of pseudo market timing across information asymmetry sub-samples around the world, at least with regard to equity issues. Said formally, we hypothesize that: 
H2: Evidence of pseudo market timing (i.e., market return's predictive power of security issuance) is similar across international sub-samples with different levels of information asymmetry.

Putting these two hypotheses together, we would expect to find evidence of both market timing and pseudo market timing in sub-samples with greater information asymmetry and evidence only of pseudo market timing in sub-samples with less information asymmetry.

\section{Empirical Model}

\section{A. A test of asymmetric information based on causality tests (Sims test)}

In this section, we provide a simple, parsimonious time-series model in which there is potential information asymmetry between informed inside managers and outside investors so that we can distinguish between market timing and pseudo market timing. In such a case, equity issue (or equity share) decisions may contain (or convey) new information about future stock returns. ${ }^{6}$ In fact, some equity issue decisions may be information events (i.e., forward-looking), while others may be noninformation events (i.e., backward-looking) with respect to stock returns. The equity issue decision will be related to future stock returns when it is an informative event under information asymmetry. The idea is that, although informed inside managers and uninformed outside investors observe the same financial variables such as current and past stock returns and fundamentals, uninformed outside investors may not recover all the information which informed inside managers use in equity issue. ${ }^{7}$ Our model is very useful because it provides a regression model that tests the predictive power of equity issue under potential information asymmetry.

\footnotetext{
${ }^{6}$ Here, we focus on the relation between equity issues (or equity share) and stock returns. However, the same logic applies to the relation between debt issues and bond returns.

${ }^{7}$ We can capture this intuition in a time-series concept of the non-invertibility of the moving average representation [see Box and Jenkins (1976, p.69) and Granger and Newbold (1986, p.145)].
} 
Here, we utilize a theorem in time-series econometrics, which states that any time-series process has both invertible and non-invertible representations [see Fuller (1976, P. 64-66, Theorem 2.6.4)]. Although stock returns may follow a general ARMA (autoregressive moving average) process, for expositional simplicity, we assume that uninformed outside investors, observing current and past stock returns, infer a first-order moving average, MA(1), process of the returns: ${ }^{8}$

$$
\mathrm{R}_{\mathrm{t}}=(1-\lambda \mathrm{L}) \mathrm{u}_{\mathrm{t}}, \quad|\lambda|<1.0
$$

where $R_{t}$ is the stock return at time $t, L$ is the lag (or backshift) operator (i.e., $L^{n} R_{t}=R_{t-n}$ ), and $u_{t}$ is white noise with $\operatorname{var}\left(\mathrm{u}_{\mathrm{t}}\right)=\sigma_{\mathrm{u}}{ }^{2}$. The autocovariance functions (ACFs) for this return process are:

$$
\begin{aligned}
& \operatorname{var}\left(R_{t}\right)=\left(1+\lambda^{2}\right) \sigma_{u}^{2}, \\
& \operatorname{cov}\left(R_{t}, R_{t-1}\right)=-\lambda \sigma_{u}^{2}, \\
& \operatorname{cov}\left(R_{t}, R_{t-k}\right)=0, \text { for } k \geq 2 .
\end{aligned}
$$

Conversely, suppose that informed inside managers, observing the same current and past stock returns, infer the following MA(1) process of the returns:

$$
\mathrm{R}_{\mathrm{t}}=\left(1-\lambda^{-1} \mathrm{~L}\right) \mathrm{v}_{\mathrm{t}}, \quad|\lambda|<1.0
$$

where $v_{t}$ is white noise with $\operatorname{var}\left(v_{t}\right)=\sigma_{v}^{2}$. The ACFs for this return process are:

$$
\begin{aligned}
& \operatorname{var}\left(R_{t}\right)=\left(1+\lambda^{-2}\right) \sigma_{v}^{2}, \\
& \operatorname{cov}\left(R_{t}, R_{t-1}\right)=-\lambda^{-1} \sigma_{v}^{2}, \\
& \operatorname{cov}\left(R_{t}, R_{t-k}\right)=0, \text { for } \mathrm{k} \geq 2 .
\end{aligned}
$$

\footnotetext{
${ }^{8}$ Any higher order representation of returns yields the same dynamic relations with more complicated computations.
} 
Note that if we set $\sigma_{\mathrm{v}}{ }^{2}=\lambda^{2} \sigma_{\mathrm{u}}{ }^{2}$, the ACFs in (2) and (4) are identical. Since the return process can be identified in practice only by the observed ACFs, the identical ACFs imply that stock return processes in (1) and (3) represent the same return process. That is, for a given return process, outside investors and inside managers may infer different MA(1) processes. ${ }^{9}$ In addition, $\sigma_{\mathrm{v}}{ }^{2}$ is smaller than $\sigma_{\mathrm{u}}{ }^{2}$ because

$$
\sigma_{\mathrm{v}}^{2}=\lambda^{2} \sigma_{\mathrm{u}}^{2}, \quad \text { and } \quad|\lambda|<1.0
$$

This means that the variance of the one-step-ahead forecast error of the return process in (3) by inside managers would be smaller than the corresponding variance of the return process in (1) by uninformed outside investors. However, unlike the $\mathrm{u}_{\mathrm{t}}$ process, the $\mathrm{v}_{\mathrm{t}}$ process cannot be recovered by uninformed investors from the information about current and past values of stock returns. ${ }^{10}$ In sum, although both inside managers and outside investors observe the same (current and past) returns, under information asymmetry informed inside managers with a larger information set $\Omega_{t}{ }^{*}=\left\{R_{t-j}, v_{t-j}, u_{t-j}\right.$, for $j \geq$ $0\}$ can forecast future returns better than uninformed investors with a smaller information set $\Omega_{t}=\left\{R_{t-j}\right.$, $\mathrm{u}_{\mathrm{t}-\mathrm{j}}$, for $\left.\mathrm{j} \geq 0\right\}$.

We can gain an important alternative insight by comparing the corresponding autoregressive representations (ARR) of the moving average representations (MAR) of stock return processes $\left\{R_{t}\right\}$ in (1) and (3):

\footnotetext{
${ }^{9}$ The return process in (1) with the innovation $u_{t}$ is an invertible MAR because the root of the determinant of the MAR of $R_{t}$ is greater than 1 (i.e., $\operatorname{det}[1-\lambda z]=0$, for $z=\lambda^{-1}$ ). However, the return process with the innovations $v_{t}$ in (3) is a non-invertible MAR because the root of the determinant is less than 1 (i.e., $\operatorname{det}\left[1-\lambda^{-1} z\right]=0$, for $z=\lambda$ ).

${ }^{10}$ This is because the process is not invertible.
} 


$$
\begin{aligned}
& \mathrm{u}_{\mathrm{t}}=(1-\lambda \mathrm{L})^{-1} \mathrm{R}_{\mathrm{t}}=\sum_{\mathrm{j}=0}^{\infty} \lambda^{\mathrm{j}} \mathrm{R}_{\mathrm{t}-\mathrm{j}} \text {, and } \\
& \mathrm{v}_{\mathrm{t}}=\left(1-\lambda^{-1} \mathrm{~L}\right)^{-1} \mathrm{R}_{\mathrm{t}}=-\left(\lambda \mathrm{L}^{-1}\right)\left(1-\lambda \mathrm{L}^{-1}\right)^{-1} \mathrm{R}_{\mathrm{t}}=-\sum_{\mathrm{j}=1}^{\infty} \lambda^{\mathrm{j}} \mathrm{R}_{\mathrm{t}+\mathrm{j}}
\end{aligned}
$$

Note that the innovations $\left\{\mathrm{u}_{\mathrm{t}}\right\}$ in the uninformed outside investors' return process are backward-looking, whereas the innovations $\left\{\mathrm{v}_{\mathrm{t}}\right\}$ in the informed inside managers' return process are forward-looking. ${ }^{11}$

How is this information asymmetry between inside managers and outside investors related to the dynamic relation between equity issue (or equity share) decisions and stock returns (i.e., the predictive power of equity issues)? Suppose that inside managers have an informational advantage in that they can forecast the firm's future prospects better than uninformed investors by observing $\mathrm{v}_{\mathrm{t}}$. If inside managers use this information in their equity issue decisions, their equity issue (or equity share, $S_{t}$ ) decision will be a function of the innovation $\mathrm{v}_{\mathrm{t}}$ that they observe but uninformed outside investors do not:

$$
S_{\mathrm{t}}=\mathrm{f}\left(\mathrm{v}_{\mathrm{t}}\right)=\sum_{\mathrm{i}=0}^{\infty}\left(\theta_{\mathrm{i}} \mathrm{L}^{\mathrm{i}}\right) \mathrm{v}_{\mathrm{t}}=\sum_{\mathrm{i}=0}^{\infty} \theta_{\mathrm{i}} \mathrm{v}_{\mathrm{t}-\mathrm{i}} \text {, with } \sum_{\mathrm{i}=0}^{\infty} \theta_{i}^{2}<\infty \text {. }
$$

Then, by using $\mathrm{v}_{\mathrm{t}}$ in (6), the equity share variable, $\mathrm{S}_{\mathrm{t}}$, and stock return processes will be related as follows:

$$
\begin{aligned}
S_{\mathrm{t}} & =\sum_{\mathrm{i}=0}^{\infty}\left(\theta_{\mathrm{i}} \mathrm{L}^{\mathrm{i}}\right) \mathrm{v}_{\mathrm{t}}=\sum_{\mathrm{i}=0}^{\infty}\left(\theta_{\mathrm{i}} \mathrm{L}^{\mathrm{i}}\right)\left\{\left(1-\lambda^{-1} \mathrm{~L}\right)^{-1} \mathrm{R}_{\mathrm{t}}\right\} \\
& =\sum_{\mathrm{i}=0}^{\infty}\left(\theta_{\mathrm{i}} \mathrm{L}^{\mathrm{i}}\right)\left(-\sum_{\mathrm{j}=1}^{\infty} \lambda^{\mathrm{j}} \mathrm{R}_{\mathrm{t}+\mathrm{j}}\right)=\sum_{\mathrm{j}=-\infty}^{\infty} \delta_{\mathrm{j}} \mathrm{R}_{\mathrm{t}-\mathrm{j}},
\end{aligned}
$$

\footnotetext{
${ }^{11}$ In practice, it would be more practical to posit the relation with an expectation operator that

$$
\mathbf{v}_{\mathrm{t}}=E_{t}\left[-\sum_{\mathrm{j}=1}^{\infty} \lambda^{\mathrm{j}} \mathbf{R}_{\mathrm{t}+\mathrm{j}}\right]
$$

The innovations $\left\{\mathrm{u}_{\mathrm{t}}\right\}$ are represented by a square summable linear combination of current and past values of $\mathrm{R}_{\mathrm{t}}$ 's (i.e., $\mathrm{u}_{\mathrm{t}}$ lies in the space spanned by current and lagged $\mathrm{R}_{\mathrm{t}}$ 's). However, the innovations $\left\{\mathrm{v}_{\mathrm{t}}\right\}$ are represented by a square summable linear combination of future values of $R_{t}$ 's (i.e., $v_{t}$ lies in the space spanned by future $R_{t}{ }^{\prime}$ ). This is because if we solve (3) backwards, the right-hand side is not square summable.
} 
where $\delta_{\mathrm{j}}$ for $\mathrm{j}=-\infty, \ldots,-2,-1,0,1,2, \ldots \infty$ is a function of $\theta_{\mathrm{i}}$ and $\lambda^{\mathrm{j}}$. That is, the equity share will be a linear combination of future, current, and past returns; thus, it will be forward-looking. In practice, since inside managers do not have perfect foresights, (7.2) will be

$$
S_{\mathrm{t}}=\sum_{\mathrm{j}=0}^{\infty} \delta_{\mathrm{j}} \mathrm{R}_{\mathrm{t}-\mathrm{j}}+\mathrm{E}_{\mathrm{t}}\left[\sum_{\mathrm{j}=-\infty}^{-1} \delta_{\mathrm{j}} \mathrm{R}_{\mathrm{t}-\mathrm{j}}\right]
$$

In contrast, suppose that inside managers do not have an informational advantage or they simply do not make equity issue (or equity share) decisions based on their informational advantage. Then, the equity share will be a function of $\mathrm{u}_{\mathrm{t}}$, the innovation that uninformed outside investors observe,:

$$
S_{\mathrm{t}}=\mathrm{f}\left(\mathrm{u}_{\mathrm{t}}\right)=\sum_{\mathrm{i}=0}^{\infty}\left(\theta_{\mathrm{i}} \mathrm{L}^{\mathrm{i}}\right) \mathrm{u}_{\mathrm{t}}=\sum_{\mathrm{i}=0}^{\infty} \theta_{\mathrm{i}} \mathrm{u}_{\mathrm{t}-1} \text {, with } \sum_{\mathrm{i}=0}^{\infty} \theta_{i}^{2}<\infty
$$

Then, by using $\mathrm{u}_{\mathrm{t}}$ in (6), equity share and stock return processes will be related as follows:

$$
\begin{aligned}
S_{\mathrm{t}} & =\sum_{\mathrm{i}=0}^{\infty}\left(\theta_{\mathrm{i}} \mathrm{L}^{\mathrm{i}}\right) \mathrm{u}_{\mathrm{t}}=\sum_{\mathrm{i}=0}^{\infty}\left(\theta_{\mathrm{i}} \mathrm{L}^{\mathrm{i}}\right)(1-\lambda \mathrm{L})^{-1} \mathrm{R}_{\mathrm{t}} \\
& =\sum_{\mathrm{i}=0}^{\infty}\left(\theta_{\mathrm{i}} L^{i}\right)\left\{\sum_{j=0}^{\infty} \lambda^{j} \mathrm{R}_{\mathrm{t}-\mathrm{j}}\right\}=\sum_{\mathrm{k}=0}^{\infty} \delta_{\mathrm{k}} \mathrm{R}_{\mathrm{t}-\mathrm{k}},
\end{aligned}
$$

where $\delta_{k}$ for $\mathrm{k}=0,1,2, \ldots \infty$ is a function of $\theta_{\mathrm{i}}$ and $\lambda^{\mathrm{j}}$. That is, in this case, the equity share will only reflect the past and current returns and will not be related to future returns; thus, it will be backwardlooking. To summarize, we have shown that under information asymmetry, informative equity issue (or equity share) decision will be related to not only past and present returns but also future returns. In contrast, in the absence of information asymmetry, non-informative equity issue (equity share) decision will not be related to future returns.

A practical question is how we distinguish between the two -- informative and non-informative -types of equity issue (or equity share) decisions. When an inside manager makes equity issue decision, if it contains new information about future prospects of the firm (i.e., stock returns) that is not contained in 
the current and past values of returns and equity issues, it is an informative (i.e., forward-looking) equity issue and it is related to future returns. Otherwise, it is a non-informative (i.e., backward-looking) equity issue. We can empirically test whether equity issue (or equity share) decisions are informative or not by using the following proposition.

The equivalence of the two-sided regression in (7.2) with Granger-causality has been established by Sims (1972, Theorem 2), which we restate in our context:

\section{Proposition 1. Consider the following two-sided regression:}

$$
S_{t}=\alpha+\sum_{j=-m}^{m} \delta_{j} R_{t-j}+\varepsilon_{t}
$$

where $E\left(\varepsilon_{t} \cdot R_{t-j}\right)=0$ for all $j(=-m . \ldots-1,0,1, \ldots m)$. If the null hypothesis that all the coefficients of future returns are zero (i.e., $\delta_{j}=\mathbf{0}$ for all $\mathbf{j}<0$ ) is rejected, then $S_{t}$ Granger-causes $\mathbf{R}_{\mathbf{t}}$.

That is, we can use the two-sided regression as a means of testing the predictability of equity issue (or equity share) for market returns, and the finding of the predictive power of equity issue can be interpreted based on information asymmetry. An intuition behind this test is that including lagged values of market returns helps us to control for potential feedback in equity issue decisions. ${ }^{12}$

\section{B. Empirical Model}

In testing the predictive power of equity issues, existing studies use a regression of current market return $\left(R_{t}\right)$ on lagged equity share in new issues $\left(S_{t-1}\right)$ :

$$
R_{t}=\alpha+\beta S_{t-1}+\varepsilon_{t},
$$

\footnotetext{
${ }^{12}$ It is interesting to note that, according to the pseudo-market timing story of Schulz (2003), both market timing and pseudomarket timing hypotheses are consistent with past returns affecting issuance decisions, which is reflected in equation (11). On the other hand, the market timing hypothesis suggests that we should observe post issuance returns, which is consistent with our claim that issuance is related to future returns in equation (11).
} 
where $S_{t}=E_{t} /\left(E_{t}+D_{t}\right)$ is the equity share variable defined as the ratio of equity issue amount $\left(E_{t}\right)$ to the sum of equity $\left(\mathrm{E}_{\mathrm{t}}\right)$ and debt issue amount $\left(\mathrm{D}_{\mathrm{t}}\right) .{ }^{13}$ Baker et al. (2006) point out that this regression may not be sufficient to differentiate the two hypotheses: market timing and pseudo-market timing hypotheses. Instead, they characterize market timing as the tendency of firms to issue equity before low equity market returns, and pseudo-market timing of Schultz (2003) as the tendency of firms to issue equity following high returns.

Given the difference between the two competing views (i.e., whether managers are able to predict a future stock price, or return, decline), one way to test the difference is to see whether equity issues help better predict future decline in returns. Since both views agree that more equity issues tend to follow higher stock prices, we also need to control for past stock price changes.

As discussed above, in our context, if equity issues (or equity shares) Granger-cause future stock returns with a negative sign, then we can interpret this as evidence of equity issue containing additional information that is not contained in past stock returns and as a result equity issues help better predict future decline in returns. Then this can be used as evidence for the market timing view. If not, equity issues do not contain additional information about future returns, and thus the pseudo market timing view is supported.

Further, given potential information asymmetry between inside managers and outside investors, it is more likely to be the case for samples and environments when and where the information asymmetry is higher and more easily exploited by managers. The use of a Granger causality test across sub-samples of disparate levels of information asymmetry can be a unique method of distinguishing between the two views in an international setting.

Equivalently, the Granger causality in (11) can be tested by the null hypothesis that $\gamma_{j}=0$ for all $\mathrm{j}>$ 0 based on the following regression:

\footnotetext{
${ }^{13}$ Domestic issues are used. In the robustness section, we will reexamine the base analysis excluding domestic issuances that have simultaneous international issues to ensure that the timing of international issues does not bias results.
} 


$$
R_{t}=\alpha+\sum_{j=1}^{m} \beta_{j} R_{t-j}+\sum_{j=1}^{m} \gamma_{j} S_{t-j}+\eta_{t}
$$

That is, we can use a one-sided Granger causality test in (13) as a means of testing the predictability of the equity share for stock market returns (i.e., market timing), and the finding of the predictive power of the equity share can be interpreted based on information asymmetry. The intuition behind this test is that including lagged values of market returns helps us to control for potential feedback in equity issue decisions. It is also interesting to note that Lucas and McDonald (1990) have developed an asymmetric information model in an attempt to explain potential predictability of equity issues, although their approach is very different from ours.

For thoroughness, we examine three measures for capital issuance previously examined in the literature - the equity share in total new equity and debt issues, the change in equity issues, or change in debt issues. ${ }^{14}$ We use the following three regressions taking into account possible feedback of equity (and/or debt) issues from past market returns:

$$
\begin{aligned}
& R_{t}^{E}=\alpha+\sum_{i=1}^{m} \beta_{i} R_{t-i}^{E}+\sum_{i=1}^{m} \gamma_{i} S_{t-i}+\varepsilon_{1 t} \\
& R_{t}^{E}=\alpha+\sum_{i=1}^{m} \beta_{i} R_{t-i}^{E}+\sum_{i=1}^{m} \gamma_{i} \Delta E_{t-i}+\varepsilon_{2 t} \\
& R_{t}^{D}=\alpha+\sum_{i=1}^{m} \beta_{i} R_{t-i}^{D}+\sum_{i=1}^{m} \gamma_{i} \Delta D_{t-i}+\varepsilon_{3 t}
\end{aligned}
$$

\footnotetext{
${ }^{14}$ Regarding the market timing of debt issues, Baker et al. (2003) find that managers have better foresight into debt market innovations than other market participants so that managers successfully anticipate and time the market by their security issuance choice. However, Butler et al. (2006) argue that the Baker et al. (2003) result is driven by a structural break in the data, and once such non-stationarities are addressed, there is no in-sample predictive power of the long term share predictor variable.

In response to the claims of Butler et al. (2005) that the predictive power of the equity share is driven by small sample bias, Baker et al. (2006) point out that aggregate pseudo-market timing is simply another name for the small-sample bias studied by Stambaugh $(1986,1999)$ and others. Baker et al. (2006) demonstrate that small sample bias is in fact too small to explain the predictive power. Therefore, the predictive power is indeed real.
} 
where $R_{t}^{E}$ in (14) and (15) is the stock market return, $R_{t}^{D}$ in (16) is the bond market return (following Henderson et al., 2006, we use 10-year interest rate swap rate), ${ }^{15} \mathrm{~S}_{\mathrm{t}}$ is the equity share in total equity and debt issues $\left(=\mathrm{E}_{\mathrm{t}} /\left(\mathrm{E}_{\mathrm{t}}+\mathrm{D}_{\mathrm{t}}\right)\right)$, and $\Delta E_{t-i}\left(\Delta D_{t-i}\right)^{16}$ is the log difference in equity (debt) issues (i.e., growth in equity/debt issues). Since this causality test can be interpreted as being based on information asymmetry as discussed above, we interpret a finding of causal relation from equity issues to market return as evidence of market timing of equity issues based on information asymmetry.

$\mathrm{S}_{\mathrm{t}}$, the equity share in total equity and debt issues, is said to Granger-cause the market return if we reject:

$\mathrm{H}_{0}: \gamma_{i}=0$, for all $\mathrm{i}$ in (14).

In other words, the equity share Granger-causes the market returns if lagged equity shares can predict current market returns, controlling for past returns. If the null $\mathrm{H}_{0}: \gamma_{i}=0$, for all $\mathrm{i}$ in (14) is rejected, we find evidence of market timing using the equity share. This specification also allows us to test the net (cumulative) effect of lagged equity shares on the market returns. Specifically, we test:

$$
\mathrm{H}_{0}: \sum_{i=1}^{m} \gamma_{i}=0 \text { in (14), }
$$

which allows us to test for the sign of the causal relation. If we find the net effect (sum of coefficients, $\left.\sum_{i=1}^{m} \gamma_{i}\right)$ is significantly negative, the sign of the causation is consistent with the expectation that managers increase equity issues relative to debt in anticipation of a drop in market return (i.e., market timing).

\footnotetext{
${ }^{15}$ Henderson et al. (2006) justify use of the swap rate of bond market interest rates since they are equivalent to the yield on a par bond issued by the most-credit worthy buyer and are thus unaffected by default risk (Footnote \#16; page 88).

${ }^{16}$ The first difference in debt and equity issues is used to address the potential unit root in these issues (see Schultz, 2004, Viswanathan and Wei, 2003 and Dahlquist and de Jong, 2008 for discussions on this).
} 
Similarly, changes in equity (debt) issues Granger-cause stock (bond) market return if we reject $\mathrm{H}_{0}$ : $\gamma_{i}=0$, for all $\mathrm{i}$ in (15) $((16))$, and the net effect of changes in equity (debt $)^{17}$ issues on the market returns can be examined by testing $\mathrm{H}_{0}: \sum_{i=1}^{m} \gamma_{i}=0$ in (15) ((16)). If the null $\mathrm{H}_{0}: \gamma_{i}=0$, for all $\mathrm{i}$ in $(15)((16))$, is rejected, we find evidence for the market timing using equity (debt) issues. The market timing theory anticipates the sign of the net effect $\sum_{i=1}^{m} \gamma_{i}$ in (15) is negative, while the sign of the net effect $\sum_{i=1}^{m} \gamma_{i}$ in (16) is positive.

The premise of the pseudo-market timing is that more firms issue equity at higher stock prices even though the market is efficient and managers have no timing ability. For the test of the pseudo-market timing, the following regression equations are specified:

$$
\begin{aligned}
& S_{t}=\alpha+\sum_{i=1}^{m} \beta_{i} R_{t-i}^{E}+\sum_{i=1}^{m} \gamma_{i} S_{t-i}+\varepsilon_{1 t}, \\
& \Delta E_{t}=\alpha+\sum_{i=1}^{m} \beta_{i} R_{t-i}^{E}+\sum_{i=1}^{m} \gamma_{i} \Delta E_{t-i}+\varepsilon_{2 t}, \\
& \Delta D_{t}=\alpha+\sum_{i=1}^{m} \beta_{i} R_{t-i}^{D}+\sum_{i=1}^{m} \delta_{i} \Delta D_{t-i}+\varepsilon_{3 t} .
\end{aligned}
$$

Similarly, the equity shares (changes in equity issues or changes in debt issues) are Granger-caused by the market returns if we reject $\mathrm{H}_{0}: \beta_{i}=0$, for all $\mathrm{i}$ in (17) ((18) or (19)). The net effect of lagged market returns on the equity shares (changes in equity issues or changes in debt issues) can be examined by testing $\mathrm{H}_{0}: \sum_{i=1}^{m} \beta_{i}=0$ in (17) ((18) or (19)). If the null $\mathrm{H}_{0}: \beta_{i}=0$, for all i in (17) ((18) or (19)) is rejected, we find evidence for the pseudo-market timing using the equity shares (equity issues or debt issues). If we

\footnotetext{
${ }^{17}$ Specifications using contemporaneous rates have also been examined with results qualitatively identical. They are available upon request.
} 
find the sign of the net effect (i.e., $\sum_{i=1}^{m} \beta_{i}$ ) in (17) is positive, this implies that firms issue more equity relative to debt following high returns on the market, which is consistent with the pseudo-market timing theory. Similarly, the pseudo-market timing theory anticipates the sign of the net effect (i.e., $\sum_{i=1}^{m} \beta_{i}$ ) in (18) and (19) is positive and negative, respectively.

Under the pseudo market timing environment, more firms issue equity at higher stock prices even though the market is efficient and managers have no market timing ability. As such, information asymmetry is not a factor and we anticipate that the different level of the information asymmetry does not make any difference between samples. However, under the market timing environment, information asymmetry can be an important factor and we anticipate to see that samples with higher (or easier to exploit) information asymmetry will show stronger evidence of the market timing.

To provide further evidence on the market timing by equity issues based on extensive international data, we group countries as common law versus civil law countries, strong versus weak investment profile countries, low versus high earnings management smoothing countries, high versus low auditor presence countries, high versus low presence of analysts countries, and high versus low institutional investors countries. Hence, if the market timing is primarily due to information asymmetry, we expect to find greater evidence of market timing in civil law, weak investment profile, high earnings management smoothing, low auditor and analyst presence as well as low institutional investor importance countries. The use of these sub-samples is further substantiated in the next section.

\section{Data and Descriptive Statistics}

Issuance data are obtained from SDC Platinum Global New Issues from 01/01/1996 through 
08/31/2009. ${ }^{18}$ Global new issues are not readily available prior to this era in SDC. We collect observations for common stock, non-convertible debt, convertible debt, non-convertible preferred stock and convertible preferred stock. ${ }^{19}$ Care is taken to note whether issuances are domestic or international. International issuances are identified following the methodology of Gozzi, Levine, and Schmukler (2009) and then dropped from the sample. Domestic issues are used in the analyses since it is these issuances that would use local market returns for market timing (or pseudo market timing). Following Schultz (2003), we exclude funds, investment companies and REITs (SIC codes 6722, 6726 and 6792) as well as offerings by utilities (SIC codes 4911-4941) and banks (6000-6081). The total number of issuances obtained through this dataset is 174,442, which includes 68,201 equity issuances and 106,241 debt issuances. A detailed list of the issuances by country of origin (50 countries) and the average principal per issue by country is given in Panel A of Table 1 .

\section{[Insert Table 1 here]}

Stock return data is obtained from Thomson Financial's Datastream. The most broadly defined index in each country is obtained to represent the return of the market. The price indices are valueweighted. Where available, the "all share" index is used. In lieu of the all share index, the next most broadly defined index is obtained. This may be problematic where individual companies represented by the issuance data are not included in the index. Using the most broadly defined index possible minimizes this possibility and resulting biases would serve to work against the market timing hypothesis (versus pseudo-market timing). Returns are collected in a monthly periodicity. A detailed list of these indexes is provided in Panel B of Table 1.

\footnotetext{
${ }^{18}$ As mentioned in the introduction, this fourteen-year term, although significant enough to perform empirical tests, is not long enough to examine structural breaks in the data as in market timing examinations done in the United States. We assume that the heterogeneity found in the cross-sectional data is significant enough that we do not pursue systematic structural breaks in the data.

${ }^{19}$ Mortgage and asset-backed securities as well as municipal bonds are not included to ensure consistency across countries where information on these securities is not available.
} 
Also collected from Datastream are the ten-year interest rate swap rates. Following Henderson et al. (2006), we use these rates for our debt issuance analysis. This methodology limits the sample in that there is limited or no data available for some of the 50 countries in our sample. Due to the number of lags in our analysis and with the implementation of the Euro relative to our sample period, we use an eight-year minimum length. Although admittedly somewhat arbitrary, the results are not sensitive to other cut-off points. A list of sample averages for the countries included is provided in Panel B of Table 1.

Countries are dropped from the original SDC Platinum New Issues list only due to lack of issuance observations in SDC Platinum or because return data is not available within Datastream. Excluding these countries results in dropping approximately one percent of the overall dataset and is not thought to bias the results in any significant way.

\section{A. Issuance Information}

Following the market timing literature, we use the "S ratio," which is defined empirically as equity principal (i.e., the amount issued) scaled by the sum of equity and debt principal $\left(S_{t}=E_{t} /\left(E_{t}+D_{t}\right)\right)$, as one of the predictors of market return. The data used to calculate this figure is obtained from the issuance data. Other predictors include changes in equity and debt levels. We define this empirically as the $\log$ difference in equity and debt issuance levels (separately) $\left(\Delta \mathrm{E}_{\mathrm{t}}\right.$ and $\left.\Delta \mathrm{D}_{\mathrm{t}}\right)$ and their lags.

\section{B. Compilation of Data}

Return data are carefully merged into the issuance data to ensure the maintenance of the relative time period. To ascertain the impact of issuance on prior and subsequent returns, it is imperative that the time period be matched carefully to ensure that the correct period is being measured. We follow Henderson et al. (2006) by using monthly issuance data and calculate returns (in our case, quarterly) using a geometric mean. With consideration of the Akaike Information criterion (1974) and the Schwarz Information criterion (1978), we use four lags in the regressions. 


\section{Creation of Sub-samples}

Sub-samples of nations in the analysis are determined through several means: legal origin, investment profile, earnings management smoothing, Big 5 Auditor presence, number of analysts, and the importance of institutional investors. Legal origin is used to examine the ultimate impact of the importance of the development of a country's legal system. This variable is chosen based on and derived from the literature finding the importance of security law and investor protection such as La Porta $e t$ al. (1997; 1998) and La Porta et al. (2006). Investment profile indices are derived from International Country Risk Guide's Investment Profile, which is a component that makes up their political risk index. The investment profile indicates the level of general stability in business that is prevalent in a country; the more (less) stability in a nation, the less (more) information asymmetry exists. ${ }^{20}$ The index is derived from data collected on nation's contract viability, expropriation, profits repatriation, and payment delays. $^{21}$ The range of investment profiles is zero to twelve, with higher numbers reflecting less risk in investment. The data is cross-sectional time-series. ${ }^{22}$

Following the accounting literature, several proxies for information asymmetry are used. As an indicator of corporate transparency, we include an indicator of the level of earnings management (Leuz et al., 2003), the presence of the Big 5 auditing firms (Bushman et al., 2004). As an indicator for how information is gathered, we include both the average number of analysts (Chang et al., 2000; Bushman et al., 2004) and the importance of institutional investors (Beck et al., 1999). Data for these variables are at a country level.

In unreported results, we also performed analysis in country development (G10 versus nonG10) and opacity. ${ }^{23}$ Results are qualitatively identical to those in this paper and are left out for brevity but are

\footnotetext{
${ }^{20}$ See Chen et al. (2010) for a discussion on how political-connectedness affects information asymmetry.

21 http://www.prsgroup.com/ICRG_Methodology.aspx

${ }^{22}$ This implies that countries are not restricted from moving from one category to another throughout its time series.

${ }^{23}$ The basis for empirical opacity is a risk premium created by Pricewaterhouse Coopers reflecting the level of information transference possible in a market. Opacity is relevant based on its effect on information asymmetry in the market (Bhattacharya et al., 2003). Data for these variables are at a country level.
} 
available upon request.

In constructing our data set, each country data are stacked very much like panel data analysis. A similar stacking scheme is used in Vuolteenaho (2002), who examines the driver of stock return volatility for U.S. firms. ${ }^{24}$ Definitions of all variables and sub-samples are found in the Appendix. Values for the bases of these sub-samples may be found in Table 2.

[Insert Table 2 here]

Bifurcation of the data is substantiated using proxies of information asymmetry from Leuz (2003). The two values used are market capitalization and total value traded. These values come from World Bank's World Development Indicators. Leuz uses these proxies to establish the level of information asymmetry in a nation. Specifically, higher values of these two proxies indicate a lower level of information asymmetry. The data is cross-sectional time-series. To substantiate the sub-samples as being different with regard to information asymmetry, we provide a difference in means test of the proposed sub-samples. Table 3 shows the results of these tests. The results clearly indicate that civil law, weak investment profile, high earnings management smoothing, low auditor/analyst presence, and low institutional investor importance nations have a statistically significant higher level of information asymmetry. Regardless of the proxy used for information asymmetry or the sub-sample examined (one exception is earnings management smoothing in the difference in means for total value traded/GDP),

\footnotetext{
${ }^{24}$ When we use cross sectional data together with time series data, potential heterogeneous characteristics in cross section data can be an important issue. Once we fail to consider potential heterogeneity in the cross sectional data, we may treat all data containing either a causal relation as a group or no causal relation as a group. However, in our case, we are mainly interested in whether different groups (e.g., common law vs. civil law group, etc.) have different causal relations as a group rather than knowing which countries have a causal relation among the group. Therefore, for our purpose, a panel causality test can be implemented assuming homogenous causal relation in each group and we naturally focus on the difference between each group as a whole, rather than some part of each group. In sum, while we are using a panel data, given our main focus, it is sufficient to pool the data for each group and implement a causal relation test assuming a homogeneous relation for each group (see, for example, Kónya, 2006; Granger, 1969; Hsiao, 1982; Holtz-Eakin, Newey, and Rosen, 1988; Judson and Owen, 1999; Hartwig, 2009a, b).
} 
there is a statistically significant difference in the means of these sub-samples, which substantiates their use in our analysis.

\section{[Insert Table 3 here]}

\section{Empirical Results}

\section{A. Market Timing}

Results for market timing show a distinction between the sub-samples. Using equity shares, Panel A of Table 4 shows greater evidence of Granger causality for all of the sub-samples with greater information asymmetry (i.e., civil law, weak investment profile, high earnings smoothing, lower auditor and analyst presence and low institutional investor importance nations) than for the sub-samples with less information asymmetry (i.e., common law, strong investment profile, low earnings smoothing, high auditor and analyst presence, and high institutional investor importance). Specifically, in specifications (2), (4), (6), (8), (10), and (12), we find that the null hypothesis that lagged equity shares, $S\left(S_{t}=E_{t} /\left(E_{t}+D_{t}\right)\right)$, as a group is insignificant (i.e., $\gamma_{i}=0$ for all i) is rejected. Though statistical significance varies across subsamples, all are significant. In the one lower information asymmetry sub-sample where we find evidence of Granger causality (i.e., low earnings management smoothing), this evidence is weaker than that of its counterpart. As suggested in the motivation section, greater evidence of Granger causality in greater information asymmetry sub-samples is interpreted to mean that in these subsamples, it is easier for insiders to exploit the information that they have relative to outsiders. ${ }^{25}$

Collectively, this evidence suggests that the equity share Granger-causes returns in the sub-samples with more information asymmetry. Their net effect (sum of coefficients, $\sum_{i=1}^{4} \gamma_{i}$ ) is significantly negative in all of the aforementioned sub-samples. The sign of the causation is consistent with the expectation that the share of equity capital would increase before a drop in market return (i.e., market timing). These

\footnotetext{
${ }^{25}$ Chow tests, though statistically significant for the paired sub-samples in Table 4, are not included because they do not affect Granger causality test results and their interpretation.
} 
results are consistent with those in Henderson et al. (2006). However, the results offer further insight into why evidence of market timing is found in some countries but not in others - information asymmetry.

[Insert Table 4 here]

The results of Panel B are not as impressive as those in Panel A. In looking at the evidence as to whether the change in equity issues $(\Delta \mathrm{E})$ has some predictive power for market returns, we find that there is only conclusive evidence of Granger causality in one sub-sample: low auditor presence. There is statistical significance for only the $\chi^{2}(1)$ test results for seven sub-samples but these are not very meaningful since the $\chi^{2}(4)$ results, which tell us if there is evidence of Granger causality, are not statistically significant, except for the low auditor presence sub sample. Though the comprehensive evidence here is considerably weak, one of the six proxies for information asymmetry shows evidence consistent with the equity share results in Panel A.

In Panel $\mathrm{C}$, we find less than consistent predictive power in the change in debt issues $(\Delta \mathrm{D})$ as well. There are no sub-samples that show evidence of Granger Causality. Three sub-samples, however, show evidence of a statistically significant positive net effect (sum of coefficients, $\sum_{i=1}^{4} \gamma_{i}$ ): high auditor presence, high analyst presence, and high institutional importance nations. It is interesting to note that all three of these sub-samples have less information asymmetry, suggesting perhaps that managers in nations where a less significant information advantage is possible try to market time using debt instruments. That said, the lack of statistical significant evidence of Granger causality weakens the impact of this evidence. The lack of evidence is not surprising once we consider the fact that the literature on the market timing of debt issuances (e.g., Barclay and Smith, 1995; Guedes and Opler, 1996; Baker, Greenwood, and Wurgler, 2003) suggests that it is the maturity of existing debt or the issuances that is of importance, not the amount. Since we do not document the maturity of the debt issued and look at rates on only ten-year interest rate swaps, this characteristics of debt is completely ignored, suggesting that the literature in this area is less comparable to the results found herein. The results on market timing of debt issues in 
Henderson et al. (2006) are likewise weak. ${ }^{26}$ Since we use the same proxy for debt market interest rates, it is comforting to find similar results.

Collectively, the evidence is not as strong for $\Delta \mathrm{E}$ and $\Delta \mathrm{D}$ as for $\mathrm{S}$. These findings support the contentions of Baker and Wurgler (2000), who suggest that equity share is a strong predictor of (U.S.) stock market returns. The evidence of a vital role of information asymmetry in environments with greater information asymmetry for equity share suggests that managers in these environments use market timing to achieve capital structure goals. This, along with the less consistent results for changes in equity and debt issues, suggests that the role of information asymmetry in changes in equity and debt individually is unclear.

\section{B. Pseudo-market Timing}

As expected, the results found in Panel A of Table 5 show no pattern of evidence of pseudo market timing in equity share $S_{t}$ regardless of the level of information asymmetry. This is intuitive in the sense that outsiders are privy to the same information as insiders (where returns are concerned) ex post. The sub-sample with low number of analysts shows a significant pseudo market timing in equity share, but its cumulative net effect on the market return is insignificant.

Panel B of Table 5 demonstrates strong evidence of market return Granger-causing the change in equity. Importantly, all of the sub-samples show evidence of Granger causality, suggesting that information asymmetry does not play a distinctive role. Once again, we expect that this should be the case ex post. The significant positive cumulative impact suggests that firms issue equity following high returns on the market, which is consistent with the pseudo-market timing theory. As discussed above, according to the pseudo market timing hypothesis, more firms issue equity at higher stock prices even though the market is efficient and managers have no market timing ability. As such, information asymmetry is not a factor and we anticipate that the different level of the information asymmetry does not make any difference between sub-samples.

\footnotetext{
${ }^{26}$ Our specification is most comparable to equation (12) of Henderson et al. (2006; p. 91).
} 
Evidence of debt market return Granger-causing change in debt issuances in our sub-samples is provided in Panel $\mathrm{C}$ of Table 5. Interestingly, the results show evidence of pseudo market timing of debt issuances primarily in sub-samples with lower levels of information asymmetry. The sign of the causality, as established by the cumulative significance, is negative, suggesting that debt issuances follow downturns in the market. This evidence is consistent with the work of Erel et al. (2010) and Gomes and Phillips (2010), both of which suggest that debt securities, which are less informationally sensitive, are used in times when there are greater levels of information asymmetry.

[Insert Table 5 here]

\section{Robustness}

\section{A. Excluding Australia and the United States}

Table 6 presents the results of robustness tests. Cross-country studies that examine equity issues often exclude Australia due to its unique form of equity rights issues. This form of offering allows the existing shareholders to decide whether they would like to accept a certain amount of shares based on a pre-determined ratio at a price lower than market value. These equity offerings are typically excluded (or the entire country in the cross-country sample) as rights issues affect firm fundamentals such as share capital, book value per share, earnings per share, and the liquidity of the stock. Since the inclusion of these observations could potentially bias the results, we provide the results after excluding Australia. In looking at the table, darker shading or unshaded boxes indicate changes from the base results. Darker shading indicates that statistical significance in the table is increased from the base results. An unshaded box represents lost statistical significance from the base results. Panel A shows that excluding Australia only changes the results slightly in the pseudo-market timing tests. Results overall substantiate those in the base analysis and do not suggest that our base results are spurious based on the inclusion of Australia.

Critics of international empirical studies often cite the influence of the United States on results since it is a powerful outlier in most studies. As such, we exclude the United States from our analysis in Panel 
B. The vast majority of results remain, though it is clear that the United States is influential. For example, we find evidence of Granger causality in strong investment profile nations as well as nations with a high analyst presence using equity share in the market timing analysis (these regions are shaded in a darker grey to represent increased significance from the base results). That said, in every information asymmetry bifurcation, sub-samples with higher information asymmetry still see stronger results, both in terms of statistical and economic significance. The qualitative results regarding market timing are unchanged when we exclude the United States. Results for pseudo market timing are also different from those in the base analysis, suggesting that the United States is relevant to the sample. The vast majority of the differences are found in the changes in debt issuances. Instead of finding evidence of Granger Causality in subsamples with lower information asymmetry, we actually find evidence of Granger Causality in three subsamples with greater information asymmetry. The results suggest that the United States is responsible for the information asymmetry pattern in the pseudo market timing analysis. The weak results for pseudo market timing of debt issues suggest that information asymmetry once again does not play a major role.

\section{[Insert Table 6 here]}

\section{B. Excluding Simultaneous International Offerings}

Since it is conceivable that market considerations across country border might contribute to any timing decisions, we exclude all issuances that involve simultaneous international offerings to ensure that these considerations are not biasing our base results. Doing so yields largely consistent results, which are seen in Panel $\mathrm{C}$ of Table 6. Though there are some differences in the market timing results using equity share, the stronger results in the sub-samples with more information asymmetry are sufficient to maintain the conclusions of the analysis in this paper.

\section{IPOs and Follow-on Offerings}

Since several studies distinguish among initial public offerings (IPOs) and follow-on offerings (e.g., SEOs), we re-examine the base analysis on these sub-samples. This comparison is particularly relevant 
since as Alti (2006, p. 1682) states, “The IPO market constitutes a natural laboratory to analyze market timing [since] investors face more uncertainty and a higher degree of asymmetric information when valuing IPO firms than they face in the case of mature public companies. Hence, IPOs offer more room for misvaluation, which is at the root of timing considerations".

The results for these analyses are found in Panels D and E of Table 6. The results of this bifurcation support the findings of Frank and Goyal $(2003 ; 2009)$, in particular, the preference of small firms (most likely those in the IPO sub-sample seen in Panel D) for equity. This isn't surprising given that IPOs involve equity issuance. This manifests in more statistical significance across sub-samples in the change in equity issuance specifications versus those with equity share. In contrast, the results for changes in equity issuances in the market timing panel of Panel E (SEO's) are less consistent with those of equity share above it in the panel. This divergence suggests that preference for equity type plays a role in the changes of specific security types. Interestingly, Panel D shows some evidence of a role for information asymmetry in pseudo market timing of equity share and changes in equity issuances for IPOs. Though these results are seemingly inconsistent with those prior, we recall that insiders definitely have an informational advantage in these cases, even ex post. The amount of underpricing and the resulting true value of the firm is still an uncertainty in the months subsequent to the IPO. ${ }^{27}$ Revelation of this information by insiders is constrained by the lock-up period for insiders. ${ }^{28}$ This is also consistent with the results of Dahlquist and de Jong (2008), who find diminished evidence of pseudo market timing in a sample of IPOs.

\section{Future Research}

The data used in the analysis are as exhaustive as possible given availability. That said, worldwide

\footnotetext{
${ }^{27}$ The amount of underpricing can vary from country to country. See, for example, Boulton et al. (2010), who find that the level of corporate governance in a nation influences the level of IPO underpricing.

${ }^{28}$ See Arthurs et al. (2009) for a discussion of how the agreed upon length of the lock-up period is important with regard to signaling quality to investors.
} 
data on securities issuance and debt market interest rates are sure to improve going forward. Though the results of equity share and changes in equity issuances are not likely to change, results of changes in debt issuances may change based on the availability of swap rates. That said, results using market rates for changes in debt issuances (i.e., how changes in debt issuances are affected through capital structure concerns) largely validate those using swap rates suggesting that these also will not likely change based on availability of data going forward. These results are available upon request.

This research begs further analysis of the timing of international issues. In this study, we explicitly limit the sample to examine domestic issuances with domestic market index returns. Given the increase in international listings, it would be interesting, however, to examine timing of international issues. Though econometrically challenging, burgeoning globalization and the mobility of capital suggest that this is an important topic for study. The inferior information of foreign investors could offer additional opportunities for managers to time capital issuance so as to minimize their cost of capital.

\section{Concluding Remarks}

The role of information asymmetry in managerial choice of securities (i.e., pecking order) and market timing (i.e., on a time dimension) have been explored in the literature. We extend the literature to consider the role of information asymmetry in market timing cross-sectionally. Specifically, we examine whether market timing (and pseudo market timing) is more prevalent in international sub-samples with greater levels of information asymmetry.

Existing studies use a regression of market returns on a lagged equity share variable to find evidence of the market timing of equity issues. We argue, as in Baker et al. (2006), that this simple regression is not effective in distinguishing between the market timing and pseudo-market timing hypotheses. We provide and implement an alternative regression model based on Granger causality test idea, which helps us distinguish between the two hypotheses. The model not only takes into account equity issues' possible feedback to past market returns but also is based on information asymmetry between inside managers and 
outside investors. Empirically, we extend the existing literature by examining an extensive dataset of international data.

Using a Granger causality framework, we find extensive evidence of both market timing and pseudomarket timing in a sample which spans 50 countries over the period 1996 through 2009. The direction of these causalities is in line with the respective theories. Analysis done on international sub-samples of the data based on the level of information asymmetry reveals that information asymmetry is a key component of a firm's ability to market time issues with equity share being the best predictor. Among different market types, we find substantial evidence of market timing of equity share in civil law, weak investment profile, high earnings management smoothing, low auditor and analyst presence, as well as low institutional investor importance markets, and evidence of pseudo-market timing of changes in equity in all sub-samples. Results also reveal that information asymmetry does not play a role in a firm's ability to pseudo market time issues.

Collectively, the results of this paper help to explain the divergence in market timing and pseudo market timing in extant literature. Specifically, the results confirm that market timing and pseudo market timing are not mutually exclusive and that information asymmetry helps to explain the patterns in evidence found in prior studies. 


\section{References}

Akaike, H., 1974, "A New Look at the Statistical Identification Model," IEEE Transactions on Automated Control, 19, 716-723.

Alti, A., 2006, "How Persistent is the Impact of Market Timing on Capital Structure?" The Journal of Finance 61, 1681-1710.

Anderson, R., A. Duru, and D. Reeb, 2009, "Founders, Heirs, and Corporate Opacity in the United States," Journal of Financial Economics 92, 205-222.

Arthurs, J., L. Busenitz, Hoskisson, R., and R. Johnson, 2009, “Signaling and Initial Public Offerings:

The Use and Impact of the Lockup Period," Journal of Business Venturing 24, 360-372.

Baker M., R. Greenwood, and J. Wurgler, 2003, “The Maturity of Debt Issues and Predictable Variation in Bond Returns," Journal of Financial Economics 70, 261-291.

Baker M., R. Taliaferro, and J. Wurgler, 2006, "Predicting Returns with Managerial Decision Variables: Is There a Small Sample Bias?” Journal of Finance 61, 1711-1730.

Baker M. and J. Wurgler, 2000, “The Equity Share in New Issues and Aggregate Stock Returns,” Journal of Finance 55, 2219-2257.

Baker M. and J. Wurgler, 2002, "Market Timing and Capital Structure,” Journal of Finance 57, 1-32.

Barclay, M. and C. Smith, 1995, “The Maturity Structure of Corporate Debt," Journal of Finance 50, 609-631.

Bayless, M. and S. Chaplinsky, 1996, "Is There a Window of Opportunity for Seasoned Equity Issuance?" The Journal of Finance 51, 253-278.

Beck, T., A. Demirguc-Kunt, and R. Levine, 1999, "A new Database on Financial Development and Structure," World Bank Economic Review 14, 597-605.

Bhattacharya U., H. Daouk, and M. Welker, 2003, "The World Price of Earnings Opacity," The Accounting Review 78, 641-678.

Boulton, T., S. Smart, and C. Zutter, 2010, "IPO Underpricing and International Corporate Governance," Journal of International Business Studies 41, 206-222.

Box, G. E. P. and G. M. Jenkins, 1976. Time Series Analysis: Forecasting and Control, Holden-Day.

Brav A., C. Geczy, and P. Gompers, 2000, "Is the Abnormal Return following Equity Issuances Anomalous?" Journal of Financial Economics 56, 209-249.

Burch T., W. Christie, and V. Nanda, 2004, "Do Firms Time Equity Offerings? Evidence from the 1930s and 1940s," Financial Management 33, 5-23.

Bushman, R., J. Piotroski, and A. Smith, 2004, "What Determines Corporate Transparency?" Journal of Accounting Research 42, 207-252. 
Butler A., G. Grullon, and J. Weston, 2005, “Can Managers Forecast Aggregate Market Returns?” Journal of Finance 60, 963-986.

Butler A., G. Grullon, and J. Weston, 2006, "Can Managers Successfully Time the Maturity Structure of Their Debt Issues?” Journal of Finance 61, 1731-1758.

Chan, Cooney, Kim Singh, 2008, “The IPO Derby: Are there Consistent Losers and Winners on this Track?" Financial Management 37, 45-79.

Chang, J., T. Khann, and K. Palepu, 2000, “Analyst Activity around the World." HBS Strategy Unit Working Paper No. 01-061.

Chang, X., H. Gilles, M-S. Chia, and L. Tam, 2010, "Conglomerate Structure and Capital Market Timing," Financial Management 39, 1307-1338.

Chemmanur, T. and K. Simonyan, 2010, "What Drives the Issuance of Putable Convertibles: RiskShifting, Asymmetric Information, or Taxes? Financial Management 39, 1027-1067.

Chen B. and Y. Liang, 2006, “Do Market Timing Hedge Funds Time the Market?” Journal of Financial and Quantitative Analysis forthcoming.

Chen, C., Y. Ding, and C. Kim, 2010, "High-level Politically Connected Firms, Corruption, and Analyst Forecast Accuracy around the World," Journal of International Business Studies 41, 1505-1524.

Dahlquist, M. and F. deJong, 2008, "Pseudo Market Timing: A Reappraisal" Journal of Financial and Quantitative Analysis 43, 547-579.

Dierkens, N., 1991, "Information Asymmetry and Equity Issues," Journal of Financial and Quantitative Analysis 26, 181-199.

Durnev, A., V. Errunza, and A. Molchanov, 2009, "Property Rights Protection, Corporate Transparency, and Growth," Journal of International Business Studies 40, 1533-1562.

Eckbo E., R. Masulis, and O. Norli, 2000, "Seasoned Public Offerings: Resolution of the 'New Issues Puzzle'," Journal of Financial Economics 56, 251-291.

Erel, I., B. Julio, W. Kim, and M. Weisbach, 2010, "Macroeconomic Conditions and the Structure of Securities," The Ohio State Univ. and NBER, Dice Center WP 2009-6 (Fisher College of Business)

Flannery, M. and K. Rangan, 2006, "Partial Adjustment toward Target Capital Structures," Journal of Financial Economics 79, 469-506.

Frank, M. and V. Goyal, 2003, "Testing the Pecking Order Theory of Capital Structure," Journal of Financial Economics 67, 217-248.

Frank, M. and V. Goyal, 2009, "Capital Structure Decisions: Which Factors are Reliably Important?," Financial Management 38, 1-37.

Fuller W., Introduction to Statistical Time Series, New York: John Wiley, 1976. 
Gao, X., J. Ritter and Z. Zhu, 2011, "Where Have All of the IPOs Gone?” Working Paper, University of Florida.

Gomes, A. and G. Phillips, 2010, "Why do Public Firms Issue Public and Private Equity, Debt and Convertibles?” Working Paper, Washington University.

Gozzi, J., R. Levine, and S. Schmukler, 2009, "Patterns of International Capital Raisings,” Journal of International Economics 80, 45-57.

Granger, C., 1969, "Investigating Causal Relations by Econometric Models and Cross-Spectral Methods," Econometrica 37, 424-438.

Granger, C. W. J. and P. Newbold, 1986. Forecasting Economic Time Series, $2^{\text {nd }}$ edition, Academic Press

Guedes, J. and T. Opler, 1996, "The Determinants of The Maturity of Corporate Debt Issues," Journal of Finance 51, 1809-1833.

Guo, L. and T. Mech, 2000, "Conditional Event Studies, Anticipation, and Asymmetric Information: The Case of Seasoned Equity Issues and Pre-issue Information Releases," Journal of Empirical Finance 7, 113-141.

Hartwig, J., 2009a, "Is Health Capital Formation Good for Long-Term Economic Growth? - Panel Granger-Causality Evidence for OECD Countries," Journal of Macroeconomics (forthcoming).

Hartwig, J., 2009b, “A Panel Granger-Causality Test of Endogenous Vs. Exogenous Growth,” ETH Zurich KOF Swiss Economic Institute, KOF Working Papers No. 231, July 2009.

Henderson B., N. Jegadeesh, and M. Weisbach, 2006, "World Markets for Raising New Capital," Journal of Financial Economics 82, 63-101.

Hirshleifer, D., 2001, “Investor Psychology and Asset Pricing,” Journal of Finance 56, 1533-1597.

Holtz-Eakin, D., W. Newey, and H. Rosen, 1988, "Estimating Vector Autoregressions with Panel Data," Econometrica 56, 1371-1395.

Hsiao, C., 1982, “Autoregressive Modeling and Causal Ordering of Economic Variables," Journal of Economic Dynamics and Control 4, 243-259.

Huang, R. and J. Ritter, 2009, "Testing Theories of Capital Structure and Estimating the Speed of Adjustment," Journal of Financial and Quantitative Analysis 44, 237-271.

Judson, R. and Owen, A., 1999, "Estimating Dynamic Panel Data Models: A Guide for Macroeconomists," Economic Letters 65, 9-15.

Kennedy, D., R. Sivakumar and K. Vetzal, 2006, "The Implications of IPO Underpricing for the Firm and Insiders: Tests of Asymmetric Information Theories," Journal of Empirical Finance 13, 49-78.

Kónya, L., 2006, "Exports and Growth: Granger Causality Analysis on OECD Countries with a Panel Approach," Economic Modelling 23, 978-992. 
Korajczyk, R., D. Lucas, and R. McDonald, 1991, “The Effect of Information Releases on the Pricing And Timing of Equity Issues," The Review of Financial Studies 4, 685-708.

Korajczyk, R., D. Lucas, and R. McDonald, 1992, "Equity Issues with Time-varying Asymmetric Information," Journal of Financial and Quantitative Analysis 27, 397-417.

La Porta R., F. Lopez-de-Silanes, and A. Shleifer, 2006, "What Works in Securities Laws?" Journal of Finance 61(1), 1-32.

La Porta R., F. Lopez-de-Silanes, A. Shleifer, and R. Vishny, 1997, "Legal Determinants of External Finance," Journal of Finance 52, 1131-1150.

La Porta R., F. Lopez-de-Silanes, A. Shleifer, and R. Vishny, 1998, "Law and Finance," Journal of Political Economy 106, 1113-1155.

Lee I., 1997, “Do Firms Knowingly Sell Overvalued Equity?” Journal of Finance 52, 1439-1466.

Lerner, J., 1994, "Venture Capitalists and the Decision to Go Public," Journal of Financial Economics 35, 293-316.

Leuz, C., 2003, "IAS versus U.S. GAAP: Information Asymmetry-based Evidence from Germany's New Market," Journal of Accounting Research 41, 445-472

Leuz, C., D. Nanda, and P. Wysocki, 2003, "Investor Protection and Earnings Management: An International Comparison," Journal of Financial Economics 69, 505-527.8

Li X. and X. Zhao, 2003, “Is There Abnormal Return after Seasoned Equity Offerings?” Working paper, Ohio State University.

Loughran T. and J. Ritter, 1995, “The New Issues Puzzle,” Journal of Finance 50, 23-51.

Loughran, T. and J. Ritter, 2000, “Uniformly Least Powerful Tests of Market Efficiency,” Journal of Financial Economics 55, 361-390.

Lucas D. and R. McDonald, 1990, “Equity Issues and Stock Dynamics,” Journal of Finance 45, 10191043.

Miller, S., D. Li, L. Eden, and M. Hitt, 2008, "Insider Trading and the Valuation of International Strategic Alliances in Emerging Stock Markets," Journal of International Business Studies 39, 102-117.

Mitchell M. and E. Stafford, 2000, "Managerial Decisions and Long-Term Stock Price Performance," Journal of Business 73, 287-320.

Myers, S. and N. Majluf, 1984, "Corporate Financing and Investment Decisions When Firms Have Information that Investors Do Not Have," Journal of Financial Economics 13,187-221.

Ritter J., 1991, “The Long-run Performance of Initial Public Offerings,” Journal of Finance 46, 3-27.

Sanders, G. and M. Carpenter, 2003, "Strategic Satisficing? A Behavioral-Agency Theory Perspective on Stock Repurchase Program Announcements,” Academy of Management Journal 46, 160-178. 
Schultz P., 2003, "Pseudo-market Timing and the Long-run Underperformance of IPOs," Journal of Finance 58, 483-517.

Schultz P., 2004, "Pseudo Market Timing and the Stationarity of the Event-Generating Process," Working Paper, University of Notre Dame.

Schwarz G., 1978, "Estimating the Dimension of a Model,” Annals of Statistics 6, 461-464.

Sims C., 1972, “Money, Income, and Causality,” American Economic Review 62, 540-552.

Spiess K. and J. Affleck-Graves, 1995, "Underperformance in Long-run Stock Returns Following Seasoned Equity Offerings," Journal of Financial Economics 38, 243-267.

Stambaugh R., 1986, "Bias in Regression with Lagged Stochastic Regression," Working Paper. University of Chicago.

Stambaugh R., 1999, "Predictive Regressions," Journal of Financial Economics 54, 375-421.

Viswanathan, S. and B. Wei, 2003, “Endogenous Events and Long Run Returns,” Working paper, Duke University.

Vuolteenaho, T., 2002, “What Drives Firm-level Stock Returns?” Journal of Finance 57, 233-264. 


\section{Appendix A. Variable Definitions}

\begin{tabular}{|c|c|}
\hline Variable & Definitions \\
\hline Common legal origin & $\begin{array}{l}\text { An indicator variable that equals one if a nation is of British legal origin and zero otherwise. Source: } \\
\text { La Porta et al. }(1997 ; 1998)\end{array}$ \\
\hline Civil legal origin & $\begin{array}{l}\text { An indicator variable that equals one if a nation is of German or French legal origin and zero } \\
\text { otherwise. Source: La Porta et al. }(1997 ; 1998)\end{array}$ \\
\hline Investment Profile & $\begin{array}{l}\text { An index that measures the general level of business stability in a nation and is derived from data on } \\
\text { contract viability, expropriation, profits repatriation, and payment delays in a nation. The range of } \\
\text { investment profiles is zero to twelve, with higher numbers reflecting less risk in investment. Source: } \\
\text { International Country Risk Guide (PRS Group) }\end{array}$ \\
\hline $\begin{array}{l}\text { Earnings management } \\
\text { smoothing }\end{array}$ & $\begin{array}{l}\text { An index from } 2 \text { (low smoothing) to } 28.3 \text { (high smoothing) of the level of earnings management } \\
\text { occurs in a nation. Source: Leuz et al., } 2003\end{array}$ \\
\hline Auditor presence & $\begin{array}{l}\text { An index from } 1 \text { (low) to } 4 \text { (high) indicating the percent of a nation's firms audited by the Big } 5 \\
\text { accounting firms (i.e., quartiles). Source: Bushman et al., } 2004\end{array}$ \\
\hline Analyst presence & $\begin{array}{l}\text { Number of analysts following a nation's largest } 30 \text { firms. Source: Bushman et al., 2004; Chang et } \\
\text { al., } 2000\end{array}$ \\
\hline Institutional investors & $\begin{array}{l}\text { Indicates the importance of institutional investors in a nation - proxied by the average of total assets } \\
\text { in pooled investment, scaled by that nation's GDP. Source: Beck et al., } 1999\end{array}$ \\
\hline Market return & The log difference of the price index from time $\mathrm{t}+1$ to time $\mathrm{t}$. Source: DataStream \\
\hline Equity share (S) & $\begin{array}{l}\text { The natural log of the equity principal scaled by the sum of equity and debt principal. Source: SDC } \\
\text { Platinum }\end{array}$ \\
\hline Change in equity $(\Delta \mathrm{E})$ & The log difference in the equity principal issues from time $\mathrm{t}$ to $\mathrm{t}-1$. Source: SDC Platinum \\
\hline Change in debt $(\Delta \mathrm{D})$ & The log difference in the debt principal issues from time $t$ to $t-1$. Source: SDC Platinum \\
\hline
\end{tabular}




\section{Table 1. Data characteristics}

This table provides information on both the number/amount of issuances (Panel A) and the indices (Panel B) used in the analysis. Issuance data are obtained from SDC Platinum from 1996-2009. Equity issuance includes IPOs, SEOs, SPACs, REITs and closed-end funds. Index returns and interest rate swap rates are obtained from DataStream. A “.” indicates no available data for a given country.

Panel A. Issuances by country

\begin{tabular}{|c|c|c|c|c|}
\hline & $\begin{array}{c}\text { Number of } \\
\text { equity issuances }\end{array}$ & $\begin{array}{c}\text { Number of } \\
\text { debt issuances }\end{array}$ & $\begin{array}{c}\text { Total number of } \\
\text { issuances }\end{array}$ & $\begin{array}{c}\text { Avg principal/yr } \\
\text { (\$ mil) }\end{array}$ \\
\hline Argentina & 88 & 210 & 298 & 161.82 \\
\hline Australia & 13,812 & 593 & 14,405 & 28.34 \\
\hline Austria & 102 & 68 & 170 & 460.90 \\
\hline Belgium & 174 & 38 & 212 & 450.42 \\
\hline Brazil & 242 & 757 & 999 & 211.86 \\
\hline Canada & 8,902 & 1987 & 10,889 & 85.02 \\
\hline Chile & 232 & 489 & 721 & 57.07 \\
\hline China & 1,377 & 355 & 1,732 & 151.20 \\
\hline Colombia & 52 & 565 & 617 & 52.10 \\
\hline Czech Republic & 9 & 3 & 12 & 286.29 \\
\hline Denmark & 234 & 30 & 264 & 198.77 \\
\hline Ecuador & 4 & 79 & 83 & 19.17 \\
\hline Egypt & 96 & 4 & 100 & 129.37 \\
\hline Finland & 216 & 60 & 276 & 231.68 \\
\hline France & 1,236 & 596 & 1,832 & 371.36 \\
\hline Germany & 1,067 & 561 & 1,628 & 431.19 \\
\hline Greece & 231 & 56 & 287 & 537.00 \\
\hline Hong Kong & 2,966 & 425 & 3,391 & 55.12 \\
\hline Hungary & 20 & 31 & 51 & 242.69 \\
\hline India & 1,973 & 2,305 & 4,278 & 31.56 \\
\hline Indonesia & 265 & 366 & 631 & 83.03 \\
\hline Ireland & 82 & 15 & 97 & 232.57 \\
\hline Israel & 44 & 7 & 51 & 122.39 \\
\hline Italy & 415 & 250 & 665 & 990.60 \\
\hline Japan & 5,651 & 6,008 & 11,659 & 125.19 \\
\hline Luxembourg & 16 & 3 & 19 & 291.67 \\
\hline Malaysia & 1,525 & 1,352 & 2,877 & 40.05 \\
\hline Mexico & 136 & 794 & 930 & 181.95 \\
\hline Netherlands & 276 & 77 & 353 & 294.05 \\
\hline New Zealand & 204 & 57 & 261 & 59.59 \\
\hline Norway & 373 & 41 & 414 & 130.43 \\
\hline Pakistan & 34 & 19 & 53 & 82.37 \\
\hline Peru & 8 & 547 & 555 & 26.94 \\
\hline Philippines & 177 & 118 & 295 & 147.49 \\
\hline Poland & 221 & 45 & 266 & 168.95 \\
\hline Portugal & 94 & 71 & 165 & 482.53 \\
\hline Russian Fed & 37 & 5 & 42 & 387.87 \\
\hline Singapore & 1,109 & 889 & 1,998 & 49.41 \\
\hline South Africa & 78 & 24 & 102 & 182.99 \\
\hline South Korea & 3,770 & 10,355 & 14,125 & 36.92 \\
\hline Spain & 212 & 176 & 388 & 625.69 \\
\hline Sri Lanka & 19 & 0 & 19 & 65.30 \\
\hline Sweden & 500 & 203 & 703 & 142.12 \\
\hline Switzerland & 242 & 501 & 743 & 205.07 \\
\hline Taiwan & 1,150 & 1,983 & 3,133 & 42.22 \\
\hline Thailand & 564 & 565 & 1,129 & 64.08 \\
\hline Turkey & 61 & 0 & 61 & 328.27 \\
\hline United Kingdom & 7,219 & 3,127 & 10,346 & 153.45 \\
\hline United States & 10,581 & 69,346 & 79,927 & 156.86 \\
\hline Venezuela & 78 & 83 & 161 & 160.88 \\
\hline Total & 68,201 & 106,241 & 174,442 & 150.60 \\
\hline
\end{tabular}


Panel B. Country Indices

\begin{tabular}{|c|c|c|c|}
\hline Country & Index & $\begin{array}{c}\text { Avg monthly } \\
\text { return }(\%)\end{array}$ & $\begin{array}{c}\text { Avg Interest Rate } \\
\text { Swap Rate (\%) }\end{array}$ \\
\hline Argentina & Argentina Merval & -0.46 & . \\
\hline Australia & ASX All Ordinaries & 0.36 & 6.40 \\
\hline Austria & Wiener Boerse Index (WBI) & 0.27 & 5.17 \\
\hline Belgium & Brussels All Share & -0.21 & 5.00 \\
\hline Brazil & Brazil (IBX) & 1.37 & . \\
\hline Canada & S\&P/TSX Composite Index & 0.39 & 5.16 \\
\hline Chile & Chile General (IGPA) & 0.32 & . \\
\hline China & Shanghai Se A Share & 0.44 & . \\
\hline Colombia & Colombia-Ds Market & 0.54 & . \\
\hline Czech Republic & PX Index & 0.51 & . \\
\hline Denmark & OMX Copenhagen (OMXC) & 0.26 & 5.49 \\
\hline Ecuador & Ecuador ECU (U\$) & 0.85 & . \\
\hline Egypt & Egypt EFG & 0.58 & . \\
\hline Finland & OMX Helsinki (OMXH) & -1.06 & 5.48 \\
\hline France & SBF250 & 0.87 & 5.24 \\
\hline Germany & DAX 200 Average & 0.51 & 5.16 \\
\hline Greece & Athex Composite & 0.76 & 5.77 \\
\hline Hong Kong & Hang Seng & 0.33 & . \\
\hline Hungary & Budapest (BUX) & 0.07 & . \\
\hline India & India BSE National & -0.07 & . \\
\hline Indonesia & Jakarta Se Composite & 0.05 & . \\
\hline Ireland-Rep & Ireland Se Overall (ISEQ) & 0.82 & 4.95 \\
\hline Israel & Tel Aviv Se General & 0.40 & . \\
\hline Italy & Milan MIB Storico General & 0.57 & 5.44 \\
\hline Japan & Topix & 0.46 & 1.84 \\
\hline Luxembourg & Luxemburg-Ds Market & 0.44 & . \\
\hline Malaysia & KLCI Composite & 0.37 & . \\
\hline Mexico & Mexico Banamex & -0.43 & . \\
\hline Netherlands & Amsterdam Se All Share & -0.06 & 5.09 \\
\hline New Zealand & NZX All & -1.00 & 6.83 \\
\hline Norway & Oslo Exchange All Share & 0.20 & 5.67 \\
\hline Pakistan & Karachi Se 100 & 0.49 & . \\
\hline Peru & Lima Se General (IGBL) & -0.30 & . \\
\hline Philippines & Philippine Se Composite & 0.23 & . \\
\hline Poland & Warsaw General Index & 0.39 & . \\
\hline Portugal & Portugal PSI General & -0.03 & 6.00 \\
\hline Russian Fed & RSF EE Mt (Rur) Index & -0.80 & . \\
\hline Singapore & Singapore All-Sing Equities & 1.23 & . \\
\hline South Africa & FTSE/JSE All Share & -0.30 & 10.02 \\
\hline South Korea & Korea Se Composite (KOSPI) & 0.20 & . \\
\hline Spain & Madrid Se General & 0.28 & 5.43 \\
\hline Sri Lanka & Colombo All Share & 0.92 & . \\
\hline Sweden & OMX Stockholm (OMXS) & -0.29 & 5.89 \\
\hline Switzerland & Swiss Market & 0.36 & 3.65 \\
\hline Taiwan & Taiwan Se Composite & -0.84 & . \\
\hline Thailand & Bangkok S.E.T. & 0.13 & 5.23 \\
\hline Turkey & ISE National 100 & -0.33 & . \\
\hline United Kingdom & FTSE All Share & 0.23 & 5.77 \\
\hline United States & Russell 3000 & 0.31 & 5.57 \\
\hline Venezuela & Venezuela Se General & 0.88 & . \\
\hline Global Average & & 0.24 & 5.30 \\
\hline
\end{tabular}


Table 2. Sub-sample Characteristics

Common/Civil Law countries refer to those countries with the respective legal origins. The investment profile indicates the level of general stability in business that is prevalent in a country. Earnings management smoothing (EMS) is an index from 2 (low smoothing) to 28.3 (high smoothing) of the level of earnings management occurs in a nation. Auditor Presence is an index from 1 (low) to 4 (high) indicating the percent of a nation's firms audited by the Big 5 accounting firms (i.e., quartiles). Analyst Presence is the average number of analysts following a nation's largest 30 firms. Institutional Investor indicates the importance of institutional investors in a nation - proxied by the average of total assets in pooled investment, scaled by that nation's GDP. Figures are averaged over the term 1996-2009. A “.” indicates no available data for a given country.

\begin{tabular}{|c|c|c|c|c|c|c|}
\hline Country & $\begin{array}{c}\text { Common } \\
\text { Law } \\
\end{array}$ & $\begin{array}{c}\text { Investment } \\
\text { Profile } \\
\end{array}$ & EMS & $\begin{array}{c}\text { Auditor } \\
\text { Presence }\end{array}$ & $\begin{array}{c}\text { Analyst } \\
\text { Presence }\end{array}$ & $\begin{array}{c}\text { Institutional } \\
\text { Investor }\end{array}$ \\
\hline Argentina & 0 & 6.85 & . & . & 12.73 & . \\
\hline Australia & 1 & 10.23 & 4.8 & 4 & 12.3 & 0.103 \\
\hline Austria & 0 & 10.11 & 28.3 & 3 & 8.63 & 0.109 \\
\hline Belgium & 0 & 10.14 & 19.5 & 3 & 15.33 & 0.059 \\
\hline Brazil & 0 & 6.99 & . & 3 & 16.1 & 0.184 \\
\hline Canada & 1 & 8.95 & 5.3 & 4 & 16.9 & . \\
\hline Chile & 0 & 10.32 & . & 4 & 5.53 & 0.069 \\
\hline China & 0 & 7.31 & . & . & . & . \\
\hline Colombia & 0 & 8.93 & . & 3 & 3.31 & . \\
\hline Czech Republic & 0 & 10.04 & . & . & . & . \\
\hline Denmark & 0 & 9.84 & 16 & 4 & 12.87 & 0.033 \\
\hline Ecuador & 0 & 6.12 & . & . & . & . \\
\hline Egypt & 0 & 6.50 & . & . & . & . \\
\hline Finland & 0 & 10.46 & 12 & 4 & 14.9 & 0.013 \\
\hline France & 0 & 10.50 & 13.5 & 3 & 23.2 & 0.371 \\
\hline Germany & 0 & 10.52 & 21.5 & 4 & 32.4 & 0.135 \\
\hline Greece & 0 & 9.87 & 28.3 & 1 & 6.1 & 0.047 \\
\hline Hong Kong & 1 & 10.12 & 19.5 & 4 & 25 & . \\
\hline Hungary & 0 & 9.50 & . & . & . & . \\
\hline India & 1 & 7.79 & 19.1 & 1 & 11.9 & 0.072 \\
\hline Indonesia & 0 & 6.63 & 18.3 & . & . & . \\
\hline Ireland-Rep & 1 & 10.77 & . & 4 & 5.43 & 0.262 \\
\hline Israel & 1 & 9.45 & . & 0 & 3.19 & 0.123 \\
\hline Italy & 0 & 10.22 & 24.8 & 4 & 21.57 & 0.072 \\
\hline Japan & 0 & 9.71 & 20.5 & 4 & 14.87 & . \\
\hline Luxembourg & 0 & 11.96 & . & 4 & 0 & . \\
\hline Malaysia & 1 & 8.21 & 14.8 & 3 & 19.9 & . \\
\hline Mexico & 0 & 9.86 & . & 3 & 18.53 & . \\
\hline Netherlands & 0 & 10.83 & 16.5 & 4 & 29.53 & 0.156 \\
\hline New Zealand & 1 & 11.53 & . & 4 & 8.87 & . \\
\hline Norway & 0 & 11.50 & 5.8 & 4 & 12.83 & 0.038 \\
\hline Pakistan & 1 & 7.63 & 17.8 & 2 & 3.4 & . \\
\hline Peru & 0 & 8.15 & . & . & 8.1 & . \\
\hline Philippines & 0 & 8.88 & 8.8 & 1 & 10.87 & . \\
\hline Poland & 0 & 10.64 & . & . & . & . \\
\hline Portugal & 0 & 10.54 & 25.1 & 3 & 5.33 & 0.101 \\
\hline Russian Fed & . & 8.84 & . & . & . & . \\
\hline Singapore & 1 & 11.02 & 21.6 & 4 & 20.9 & . \\
\hline South Africa & 1 & 10.38 & 5.6 & 4 & 7.4 & 0.035 \\
\hline South Korea & 0 & 8.62 & 26.8 & . & . & . \\
\hline Spain & 0 & 11.14 & 18.6 & 4 & 22.73 & 0.163 \\
\hline Sri Lanka & 1 & . & . & . & 2.4 & . \\
\hline Sweden & 0 & 7.83 & 6.8 & 4 & 20.6 & 0.097 \\
\hline Switzerland & 0 & 9.65 & 22 & 3 & 19.97 & 0.155 \\
\hline Taiwan & 0 & 10.57 & 22.5 & 2 & 6.8 & . \\
\hline Thailand & 1 & 8.50 & 18.3 & 3 & 9.77 & . \\
\hline Turkey & 0 & 8.13 & . & 1 & 7.97 & . \\
\hline United Kingdom & 1 & 11.90 & 7 & 4 & 20.1 & 0.126 \\
\hline United States & 1 & 10.89 & 2 & 4 & 30.23 & 0.225 \\
\hline Venezuela & 0 & 4.56 & . & 3 & 1.67 & 0.067 \\
\hline
\end{tabular}




\section{Table 3. Difference in Means}

Common/Civil Law countries refer to those countries with the respective legal origins. The investment profile indicates the level of general stability in business that is prevalent in a country. Earnings management smoothing (EMS) is an indication of the level of earnings management occurs in a nation. Auditor Presence is an index from 1 (low) to 4 (high) indicating the percent of a nation's firms audited by the Big 5 accounting firms (i.e., quartiles). Analyst Presence is the number of analysts following a nation's largest 30 firms. Institutional Investor indicates the importance of institutional investors in a nation - proxied by the average of total assets in pooled investment, scaled by that nation's GDP. Market capitalization is the aggregate value of a nation's stock market. Total value traded is the aggregate value of the stocks traded in a nation. Observations are country-month and are based on the maximum number of observations included in the base analysis in Table 4 ( $\mathrm{N}=4,818$ ). Ful sample $(4,045)$ does not equal 4,818 due to missing observations of market capitalization and total value traded.

\begin{tabular}{|c|c|c|c|c|c|c|c|c|c|}
\hline Characteristic tested & $\mathbf{N}$ & $\begin{array}{c}\text { Market } \\
\text { capitalization } \\
\text { (\% of GDP) }\end{array}$ & $\begin{array}{c}\text { Difference test } \\
\text { statistic }\end{array}$ & $\begin{array}{c}\text { Market } \\
\text { capitalization } \\
\text { (current \$'s) }\end{array}$ & $\begin{array}{c}\text { Difference } \\
\text { test statistic } \\
\end{array}$ & $\begin{array}{c}\text { Total value } \\
\text { traded }(\% \text { of } \\
\text { GDP) }\end{array}$ & $\begin{array}{c}\text { Difference test } \\
\text { statistic }\end{array}$ & $\begin{array}{c}\text { Total value } \\
\text { traded } \\
\text { (current \$'s) }\end{array}$ & $\begin{array}{c}\text { Difference test } \\
\text { statistic }\end{array}$ \\
\hline Full sample & 4,045 & 94.00 & & $1.12 \mathrm{e}+12$ & & 74.60 & & $1.58 \mathrm{e}+12$ & \\
\hline $\begin{array}{l}\text { Common legal origin } \\
\text { Civil legal origin }\end{array}$ & $\begin{array}{l}1,160 \\
2,212\end{array}$ & $\begin{array}{c}146.19 \\
66.64\end{array}$ & $79.55 * * *$ & $\begin{array}{l}2.29 \mathrm{e}+12 \\
5.72 \mathrm{e}+11\end{array}$ & $1.71 \mathrm{e}+12 * * *$ & $\begin{array}{c}107.85 \\
57.17\end{array}$ & $50.67 * * *$ & $\begin{array}{l}3.44 \mathrm{e}+12 \\
5.98 \mathrm{e}+11\end{array}$ & $2.84 \mathrm{e}+12 * * *$ \\
\hline $\begin{array}{l}\text { Strong Investment Profile } \\
\text { Weak investment Profile }\end{array}$ & $\begin{array}{l}2,873 \\
1,790\end{array}$ & $\begin{array}{c}101.18 \\
72.43\end{array}$ & $28.75 * * *$ & $\begin{array}{l}1.36 \mathrm{e}+12 \\
5.08 \mathrm{e}+11\end{array}$ & $8.53 \mathrm{e}+11 * * *$ & $\begin{array}{l}92.78 \\
49.45\end{array}$ & $43.34 * * *$ & $\begin{array}{l}1.80 \mathrm{e}+12 \\
5.49 \mathrm{e}+11\end{array}$ & $1.25 \mathrm{e}+11 * * *$ \\
\hline $\begin{array}{l}\text { Low earnings smoothing } \\
\text { High earnings smoothing }\end{array}$ & $\begin{array}{l}1,537 \\
1,967\end{array}$ & $\begin{array}{l}108.14 \\
102.79\end{array}$ & $5.32 *$ & $\begin{array}{l}2.08 \mathrm{e}+12 \\
6.63 \mathrm{e}+11\end{array}$ & $1.41 \mathrm{e}+12 * * *$ & $\begin{array}{l}96.62 \\
94.23\end{array}$ & 2.39 & $\begin{array}{l}2.92 \mathrm{e}+12 \\
7.05 \mathrm{e}+11\end{array}$ & $2.21 \mathrm{e}+12 * * *$ \\
\hline $\begin{array}{l}\text { High auditor presence } \\
\text { Low auditor presence }\end{array}$ & $\begin{array}{l}2,298 \\
1,568\end{array}$ & $\begin{array}{c}116.90 \\
76.26\end{array}$ & $40.64 * * *$ & $\begin{array}{l}1.73 e+12 \\
3.55 e+11\end{array}$ & $1.37 \mathrm{e}+12 * * *$ & $\begin{array}{l}98.62 \\
54.61\end{array}$ & $44.01 * * *$ & $\begin{array}{l}2.32 \mathrm{e}+12 \\
2.93 \mathrm{e}+11\end{array}$ & $2.02 \mathrm{e}+12 * * *$ \\
\hline $\begin{array}{l}\text { High number of analysts } \\
\text { Low number of analysts }\end{array}$ & $\begin{array}{l}2,963 \\
1,082\end{array}$ & $\begin{array}{c}111.44 \\
59.33\end{array}$ & 52.11*** & $\begin{array}{l}1.50 \mathrm{e}+12 \\
8.95 \mathrm{e}+10\end{array}$ & $1.41 \mathrm{e}+12 * * *$ & $\begin{array}{l}96.57 \\
23.77\end{array}$ & $\mathbf{7 2 . 8 0} * * *$ & $\begin{array}{l}1.93 \mathrm{e}+12 \\
4.64 \mathrm{e}+10\end{array}$ & $1.89 \mathrm{e}+12 * * *$ \\
\hline $\begin{array}{l}\text { High institutional investor } \\
\text { Low institutional investor }\end{array}$ & $\begin{array}{l}2,864 \\
1,181\end{array}$ & $\begin{array}{c}105.32 \\
78.55\end{array}$ & $26.77 * * *$ & $\begin{array}{l}1.48 \mathrm{e}+12 \\
2.62 \mathrm{e}+11\end{array}$ & $1.21 \mathrm{e}+12 * * *$ & $\begin{array}{l}86.50 \\
51.66\end{array}$ & $34.84 * * *$ & $\begin{array}{l}1.92 \mathrm{e}+12 \\
2.19 \mathrm{e}+11\end{array}$ & $1.67 \mathrm{e}+12 * * *$ \\
\hline
\end{tabular}


The following regression equation is specified:

Table 4. Market Timing

$$
R_{t}^{E}=\alpha+\sum_{i=1}^{4} \beta_{i} R_{t-i}^{E}+\sum_{i=1}^{4} \gamma_{i} S_{t-i}+\varepsilon_{1 t} \text {, in Panel A, }
$$

where $R_{t}^{E}$ is the stock return for month $\mathrm{t}, \mathrm{S}_{\mathrm{t}}$ is the ratio of the (equity principal/(equity principal + debt principal)) in month t. Common/Civil Law countries refer to those countries with the respective legal origins. The investment profile indicates the level of general stability in business that is prevalent in a country. Earnings management smoothing (EMS) is an index from 2 (low smoothing) to 28.3 (high smoothing) of the level of earnings management occurs in a nation. Auditor Presence is an index from 1 (low) to 4 (high) indicating the percent of a nation's firms audited by the Big 5 accounting firms (i.e., quartiles). Analyst Presence is the number of analysts following a nation's largest 30 firms. Institutional Investor indicates the importance of institutional investors in a nation - proxied by the average of total assets in pooled investment, scaled by that nation's GDP. The $\chi^{2}(4)$ tests the null hypothesis that each lagged coefficient of $S_{t}$ is zero. The $\chi^{2}(1)$ tests the null hypothesis that the sum of lagged coefficients of $\mathrm{S}_{\mathrm{t}}$ is zero. Standard errors are given in brackets. *,**,*** indicate significance levels of 10,5 , and 1 percent, respectively. Shaded cells indicate evidence of significant test results.

Panel A. Equity Share

\begin{tabular}{|c|c|c|c|c|c|c|c|c|c|c|c|c|}
\hline Dependent $V$ & \multicolumn{2}{|c|}{$\begin{array}{c}\text { Legal } \\
\text { Origin }\end{array}$} & \multicolumn{2}{|c|}{ Investment Profile } & \multicolumn{2}{|c|}{$\begin{array}{c}\text { Earnings Management } \\
\text { Smoothing }\end{array}$} & \multicolumn{2}{|c|}{$\begin{array}{c}\text { Big } 5 \\
\text { Auditors Presence }\end{array}$} & \multicolumn{2}{|c|}{$\begin{array}{l}\text { Number of } \\
\text { Analysts }\end{array}$} & \multicolumn{2}{|c|}{$\begin{array}{l}\text { Institutional } \\
\text { Investors }\end{array}$} \\
\hline & Common & Civil & Strong & Weak & Low & High & High & Low & High & Low & High & Low \\
\hline & 1 & 2 & 3 & 4 & 5 & 6 & 7 & 8 & 9 & 10 & 11 & 12 \\
\hline $\mathrm{R}_{\mathrm{t}-1}^{\mathrm{E}}$ & $0.410^{* * * *}$ & $0.212^{* * * *}$ & $0.244 * * *$ & $0.248^{* * * *}$ & $0.375^{* * * *}$ & $0.273 * * *$ & $0.302 * * *$ & $0.205^{* * * *}$ & $0.335^{* * * *}$ & $0.174 * * *$ & $0.286 * * *$ & $0.166^{* * * *}$ \\
\hline$R_{t-2}^{E}$ & $\begin{array}{c}{[0.029]} \\
0.126^{* * *} \\
{[0.029]}\end{array}$ & $\begin{array}{c}{[0.018]} \\
0.02 \\
{[0.018]}\end{array}$ & $\begin{array}{c}{[0.018]} \\
0.048^{* * * *} \\
{[0.017]}\end{array}$ & $\begin{array}{c}{[0.023]} \\
0.043^{*} \\
{[0.023]}\end{array}$ & $\begin{array}{c}{[0.026]} \\
-0.003 \\
{[0.025]}\end{array}$ & $\begin{array}{c}{[0.021]} \\
0.123 * * * \\
{[0.021]}\end{array}$ & $\begin{array}{c}{[0.020]} \\
0.029 \\
{[0.020]}\end{array}$ & $\begin{array}{c}{[0.023]} \\
0.048^{* *} \\
{[0.022]}\end{array}$ & $\begin{array}{c}{[0.019]} \\
0.051^{* * *} \\
{[0.019]}\end{array}$ & $\begin{array}{c}{[0.025]} \\
0.02 \\
{[0.024]}\end{array}$ & $\begin{array}{c}{[0.018]} \\
0.053^{* * *} \\
{[0.017]}\end{array}$ & $\begin{array}{l}{[0.028]} \\
-0.004 \\
{[0.027]}\end{array}$ \\
\hline$R_{t-3}^{E}$ & $\begin{array}{c}-0.432 * * * \\
{[0.029]}\end{array}$ & $\begin{array}{c}-0.244 * * * \\
{[0.018]}\end{array}$ & $\begin{array}{c}-0.262 * * * \\
{[0.017]}\end{array}$ & $\begin{array}{c}-0.306 * * * \\
{[0.023]}\end{array}$ & $\begin{array}{c}-0.334 * * * \\
{[0.025]}\end{array}$ & $\begin{array}{c}-0.317 * * * \\
{[0.022]}\end{array}$ & $\begin{array}{c}-0.316^{* * *} * \\
{[0.021]}\end{array}$ & $\begin{array}{c}-0.278 * * * \\
{[0.023]}\end{array}$ & $\begin{array}{c}-0.321 * * * \\
{[0.019]}\end{array}$ & $\begin{array}{c}-0.249 * * * \\
{[0.024]}\end{array}$ & $\begin{array}{c}-0.293 * * * \\
{[0.017]}\end{array}$ & $\begin{array}{c}-0.272 * * * \\
{[0.028]}\end{array}$ \\
\hline$R_{t-4}^{E}$ & $\begin{array}{c}0.108 * * * \\
{[0.030]}\end{array}$ & $\begin{array}{c}0.028 \\
{[0.018]}\end{array}$ & $\begin{array}{l}0.032 * \\
{[0.018]}\end{array}$ & $\begin{array}{l}0.046^{*} \\
{[0.024]}\end{array}$ & $\begin{array}{c}0.131 * * * \\
{[0.026]}\end{array}$ & $\begin{array}{c}0.019 \\
{[0.022]}\end{array}$ & $\begin{array}{c}0.130 * * * \\
{[0.021]}\end{array}$ & $\begin{array}{l}-0.021 \\
{[0.023]}\end{array}$ & $\begin{array}{c}0.100 * * * \\
{[0.020]}\end{array}$ & $\begin{array}{l}-0.016 \\
{[0.024]}\end{array}$ & $\begin{array}{c}0.021 \\
{[0.018]}\end{array}$ & $\begin{array}{c}0.082 * * * \\
{[0.029]}\end{array}$ \\
\hline$S_{t-1}$ & $\begin{array}{c}-0.228 \\
{[0.269]}\end{array}$ & $\begin{array}{c}-0.411 * * \\
{[0.169]}\end{array}$ & $\begin{array}{c}-0.390 * * \\
{[0.156]}\end{array}$ & $\begin{array}{c}-0.433^{*} \\
{[0.239]}\end{array}$ & $\begin{array}{c}-0.474 * * \\
{[0.238]}\end{array}$ & $\begin{array}{c}-0.448 * * \\
{[0.178]}\end{array}$ & $\begin{array}{c}-0.227 \\
{[0.171]}\end{array}$ & $\begin{array}{c}-0.641 * * * \\
{[0.216]}\end{array}$ & $\begin{array}{c}-0.353 * * \\
{[0.167]}\end{array}$ & $\begin{array}{c}-0.705 * * * \\
{[0.232]}\end{array}$ & $\begin{array}{c}-0.335^{* *} \\
{[0.154]}\end{array}$ & $\begin{array}{c}-0.855 * * * \\
{[0.278]}\end{array}$ \\
\hline $\mathrm{S}_{\mathrm{t}-2}$ & $\begin{array}{c}-0.26 \\
{[0.256]}\end{array}$ & $\begin{array}{c}-0.518 * * * \\
{[0.172]}\end{array}$ & $\begin{array}{c}-0.238 \\
{[0.154]}\end{array}$ & $\begin{array}{c}-0.734 * * * \\
{[0.240]}\end{array}$ & $\begin{array}{c}-0.661 * * * \\
{[0.236]}\end{array}$ & $\begin{array}{c}-0.516 * * * \\
{[0.177]}\end{array}$ & $\begin{array}{c}-0.063 \\
{[0.167]}\end{array}$ & $\begin{array}{c}-0.697 * * * \\
{[0.221]}\end{array}$ & $\begin{array}{l}-0.306^{*} \\
{[0.163]}\end{array}$ & $\begin{array}{c}-0.537 * * \\
{[0.238]}\end{array}$ & $\begin{array}{c}-0.304 * * \\
{[0.155]}\end{array}$ & $\begin{array}{c}-0.705^{* *} * \\
{[0.274]}\end{array}$ \\
\hline$S_{t-3}$ & $\begin{array}{l}-0.007 \\
{[0.254]}\end{array}$ & $\begin{array}{c}-0.144 \\
{[0.171]}\end{array}$ & $\begin{array}{c}-0.03 \\
{[0.155]}\end{array}$ & $\begin{array}{c}-0.077 \\
{[0.238]}\end{array}$ & $\begin{array}{c}0.17 \\
{[0.235]}\end{array}$ & $\begin{array}{c}0.021 \\
{[0.177]}\end{array}$ & $\begin{array}{c}-0.173 \\
{[0.166]}\end{array}$ & $\begin{array}{l}-0.111 \\
{[0.223]}\end{array}$ & $\begin{array}{l}-0.117 \\
{[0.164]}\end{array}$ & $\begin{array}{l}-0.105 \\
{[0.233]}\end{array}$ & $\begin{array}{l}-0.016 \\
{[0.154]}\end{array}$ & $\begin{array}{l}-0.463^{*} \\
{[0.280]}\end{array}$ \\
\hline $\mathrm{S}_{\mathrm{t}-4}$ & $\begin{array}{c}0.273 \\
{[0.260]}\end{array}$ & $\begin{array}{c}-0.152 \\
{[0.166]}\end{array}$ & $\begin{array}{c}-0.039 \\
{[0.150]}\end{array}$ & $\begin{array}{c}0.179 \\
{[0.237]}\end{array}$ & $\begin{array}{c}0.3 \\
{[0.239]}\end{array}$ & $\begin{array}{c}0.097 \\
{[0.172]}\end{array}$ & $\begin{array}{l}-0.085 \\
{[0.165]}\end{array}$ & $\begin{array}{c}0.188 \\
{[0.213]}\end{array}$ & $\begin{array}{c}0.036 \\
{[0.164]}\end{array}$ & $\begin{array}{c}0.077 \\
{[0.224]}\end{array}$ & $\begin{array}{c}0.033 \\
{[0.152]}\end{array}$ & $\begin{array}{c}-0.014 \\
{[0.269]}\end{array}$ \\
\hline Constant & $\begin{array}{c}0.289 \\
{[0.343]}\end{array}$ & $\begin{array}{c}1.079 * * * \\
{[0.292]}\end{array}$ & $\begin{array}{c}0.780 * * * \\
{[0.282]}\end{array}$ & $\begin{array}{c}1.034 * * * * \\
{[0.360]}\end{array}$ & $\begin{array}{c}0.802^{* *} \\
{[0.397]}\end{array}$ & $\begin{array}{c}0.781 * * \\
{[0.307]}\end{array}$ & $\begin{array}{c}0.714 * * \\
{[0.299]}\end{array}$ & $\begin{array}{c}1.117 * * * \\
{[0.386]}\end{array}$ & $\begin{array}{c}0.781 * * * \\
{[0.261]}\end{array}$ & $\begin{array}{c}1.219 * * * \\
{[0.424]}\end{array}$ & $\begin{array}{c}0.664 * * * * \\
{[0.253]}\end{array}$ & $\begin{array}{c}1.988 * * * \\
{[0.537]}\end{array}$ \\
\hline Observations & 1,160 & 2,868 & 3,022 & 1,796 & 1,537 & 2,116 & 2,298 & 1,723 & 2,691 & 1,509 & 3,013 & 1,187 \\
\hline \# Countries & 14 & 35 & 44 & 38 & 13 & 18 & 20 & 18 & 21 & 20 & 29 & 12 \\
\hline Model $\chi^{2}$ & 435.38 & 346.01 & 429.16 & 305.6 & 406.82 & 434.98 & 439.18 & 264.37 & 580.24 & 186.87 & 576.18 & 150.64 \\
\hline$\chi^{2}(4): S$ & 2.19 & $13.61 * * *$ & 7.80 & $10.86^{* *}$ & $11.20^{* * *}$ & $12.63^{* * *}$ & 3.51 & $15.76^{* * *}$ & 7.78 & $11.51^{* * *}$ & 7.33 & $14.59 * * *$ \\
\hline (p-value) & 0.70 & 0.00 & 0.10 & 0.03 & 0.02 & 0.01 & 0.48 & 0.00 & 0.10 & 0.02 & 0.12 & 0.00 \\
\hline$\chi^{2}(1): S$ & 0.27 & $10.17^{* * *}$ & 4.30 ** & $4.35^{* *}$ & 2.13 & $4.46 * *$ & 2.52 & $5.89 * *$ & $5.12 * *$ & $5.60 * *$ & $3.63^{*}$ & $10.32 * * *$ \\
\hline (p-value) & 0.60 & 0.00 & 0.04 & 0.04 & 0.14 & 0.03 & 0.11 & 0.02 & 0.02 & 0.02 & 0.06 & 0.00 \\
\hline Sum of Coef. & -0.22 & $-1.22 * * *$ & $-0.70 * *$ & $-1.06^{* *}$ & -0.67 & $-0.85^{* *}$ & -0.55 & $-1.26^{* *}$ & $-.74 * *$ & $-1.27 * *$ & $-0.62 *$ & $-2.04 * * *$ \\
\hline
\end{tabular}


Table 4. Market Timing (cont.)

Panel B. Changes in Equity

\begin{tabular}{|c|c|c|c|c|c|c|c|c|c|c|c|c|}
\hline \multicolumn{13}{|c|}{ Dependent Variable $=\mathbf{R}_{t}$} \\
\hline & \multicolumn{2}{|c|}{$\begin{array}{l}\text { Legal } \\
\text { Origin }\end{array}$} & \multicolumn{2}{|c|}{ Investment Profile } & \multicolumn{2}{|c|}{$\begin{array}{l}\text { Earnings Management } \\
\text { Smoothing }\end{array}$} & \multicolumn{2}{|c|}{$\begin{array}{c}\text { Big } 5 \\
\text { Auditors Presence }\end{array}$} & \multicolumn{2}{|c|}{$\begin{array}{c}\text { Number of } \\
\text { Analysts }\end{array}$} & \multicolumn{2}{|c|}{$\begin{array}{l}\text { Institutional } \\
\text { Investors }\end{array}$} \\
\hline & Common & Civil & Strong & Weak & Low & High & High & Low & High & Low & High & Low \\
\hline & 1 & 2 & 3 & 4 & 5 & 6 & 7 & 8 & 9 & 10 & 11 & 12 \\
\hline $\mathrm{R}_{\mathrm{t}-1}^{\mathrm{E}}$ & $\begin{array}{c}0.411 * * * \\
{[0.029]}\end{array}$ & $\begin{array}{c}0.214 * * * \\
{[0.018]}\end{array}$ & $\begin{array}{c}0.244 * * * \\
{[0.018]}\end{array}$ & $\begin{array}{c}0.250 * * * \\
{[0.023]}\end{array}$ & $\begin{array}{c}0.368 * * * \\
{[0.025]}\end{array}$ & $\begin{array}{c}0.276 * * * \\
{[0.021]}\end{array}$ & $\begin{array}{c}0.303 * * * \\
{[0.020]}\end{array}$ & $\begin{array}{c}0.209 * * * \\
{[0.023]}\end{array}$ & $\begin{array}{c}0.337 * * * * \\
{[0.019]}\end{array}$ & $\begin{array}{c}0.178 * * * \\
{[0.025]}\end{array}$ & $\begin{array}{c}0.287 * * * \\
{[0.018]}\end{array}$ & $\begin{array}{c}0.177^{* * *} \\
{[0.028]}\end{array}$ \\
\hline $\mathrm{R}_{\mathrm{t}-2}^{\mathrm{E}}$ & $\begin{array}{c}0.128^{* * * *} \\
{[0.029]}\end{array}$ & $\begin{array}{c}0.021 \\
{[0.018]}\end{array}$ & $\begin{array}{c}0.050 * * * \\
{[0.017]}\end{array}$ & $\begin{array}{l}0.044^{*} \\
{[0.023]}\end{array}$ & $\begin{array}{l}-0.002 \\
{[0.025]}\end{array}$ & $\begin{array}{c}0.120^{* * * *} \\
{[0.021]}\end{array}$ & $\begin{array}{c}0.033 \\
{[0.020]}\end{array}$ & $\begin{array}{c}0.049^{* *} \\
{[0.022]}\end{array}$ & $\begin{array}{c}0.054 * * * \\
{[0.019]}\end{array}$ & $\begin{array}{c}0.018 \\
{[0.024]}\end{array}$ & $\begin{array}{c}0.055^{* * *} \\
{[0.017]}\end{array}$ & $\begin{array}{l}-0.003 \\
{[0.027]}\end{array}$ \\
\hline$R_{t-3}^{E}$ & $\begin{array}{c}-0.425 * * * \\
{[0.029]}\end{array}$ & $\begin{array}{c}-0.243 * * * \\
{[0.018]}\end{array}$ & $\begin{array}{c}-0.258 * * * \\
{[0.017]}\end{array}$ & $\begin{array}{c}-0.301 * * * * \\
{[0.024]}\end{array}$ & $\begin{array}{c}-0.331 * * * \\
{[0.025]}\end{array}$ & $\begin{array}{c}-0.315^{* * * *} \\
{[0.022]}\end{array}$ & $\begin{array}{c}-0.310 * * * \\
{[0.021]}\end{array}$ & $\begin{array}{c}-0.273 * * * \\
{[0.023]}\end{array}$ & $\begin{array}{c}-0.316^{* * * *} \\
{[0.019]}\end{array}$ & $\begin{array}{c}-0.250 * * * \\
{[0.024]}\end{array}$ & $\begin{array}{c}-0.289 * * * \\
{[0.017]}\end{array}$ & $\begin{array}{c}-0.271 * * * \\
{[0.028]}\end{array}$ \\
\hline$R_{t-4}^{E}$ & $\begin{array}{c}0.108 * * * \\
{[0.030]}\end{array}$ & $\begin{array}{c}0.028 \\
{[0.019]}\end{array}$ & $\begin{array}{l}0.032^{*} \\
{[0.018]}\end{array}$ & $\begin{array}{c}0.049 * * \\
{[0.024]}\end{array}$ & $\begin{array}{c}0.131 * * * \\
{[0.026]}\end{array}$ & $\begin{array}{c}0.024 \\
{[0.022]}\end{array}$ & $\begin{array}{c}0.132 * * * \\
{[0.021]}\end{array}$ & $\begin{array}{l}-0.015 \\
{[0.023]}\end{array}$ & $\begin{array}{c}0.102 * * * \\
{[0.020]}\end{array}$ & $\begin{array}{l}-0.013 \\
{[0.024]}\end{array}$ & $\begin{array}{c}0.023 \\
{[0.018]}\end{array}$ & $\begin{array}{c}0.087 * * * \\
{[0.029]}\end{array}$ \\
\hline$\Delta \mathrm{E}_{\mathrm{t}-1}$ & $\begin{array}{l}-0.001 \\
{[0.002]}\end{array}$ & $\begin{array}{c}0.000 \\
{[0.004]}\end{array}$ & $\begin{array}{c}-0.003 * * \\
{[0.002]}\end{array}$ & $\begin{array}{c}0.000 \\
{[0.005]}\end{array}$ & $\begin{array}{c}-0.002 \\
{[0.002]}\end{array}$ & $\begin{array}{c}-0.002 \\
{[0.004]}\end{array}$ & $\begin{array}{c}-0.003 * * \\
{[0.001]}\end{array}$ & $\begin{array}{c}-0.015^{*} \\
{[0.009]}\end{array}$ & $\begin{array}{c}-0.003^{*} \\
{[0.002]}\end{array}$ & $\begin{array}{c}-0.008 \\
{[0.007]}\end{array}$ & $\begin{array}{l}-0.003 * \\
{[0.002]}\end{array}$ & $\begin{array}{c}-0.011 \\
{[0.010]}\end{array}$ \\
\hline$\Delta \mathrm{E}_{\mathrm{t}-2}$ & $\begin{array}{c}-0.003 \\
{[0.002]}\end{array}$ & $\begin{array}{l}-0.001 \\
{[0.005]}\end{array}$ & $\begin{array}{c}-0.004 * * \\
{[0.002]}\end{array}$ & $\begin{array}{c}-0.005 \\
{[0.006]}\end{array}$ & $\begin{array}{c}-0.003 \\
{[0.002]}\end{array}$ & $\begin{array}{l}-0.009^{*} \\
{[0.005]}\end{array}$ & $\begin{array}{c}-0.003^{* *} \\
{[0.002]}\end{array}$ & $\begin{array}{c}-0.028^{* *} \\
{[0.012]}\end{array}$ & $\begin{array}{c}-0.004 * * \\
{[0.002]}\end{array}$ & $\begin{array}{l}-0.011 \\
{[0.008]}\end{array}$ & $\begin{array}{l}-0.004 * \\
{[0.002]}\end{array}$ & $\begin{array}{l}-0.024 * \\
{[0.014]}\end{array}$ \\
\hline$\Delta \mathrm{E}_{\mathrm{t}-3}$ & $\begin{array}{l}-0.002 \\
{[0.002]}\end{array}$ & $\begin{array}{c}-0.004 \\
{[0.005]}\end{array}$ & $\begin{array}{c}-0.005^{* *} * \\
{[0.002]}\end{array}$ & $\begin{array}{c}-0.006 \\
{[0.006]}\end{array}$ & $\begin{array}{c}-0.003 * * \\
{[0.002]}\end{array}$ & $\begin{array}{l}-0.007 \\
{[0.005]}\end{array}$ & $\begin{array}{c}-0.004 * * \\
{[0.002]}\end{array}$ & $\begin{array}{l}-0.020^{*} \\
{[0.012]}\end{array}$ & $\begin{array}{c}-0.004 * * \\
{[0.002]}\end{array}$ & $\begin{array}{l}-0.004 \\
{[0.008]}\end{array}$ & $\begin{array}{c}-0.004 * * \\
{[0.002]}\end{array}$ & $\begin{array}{c}-0.014 \\
{[0.014]}\end{array}$ \\
\hline$\Delta \mathrm{E}_{\mathrm{t}-4}$ & $\begin{array}{l}-0.001 \\
{[0.002]}\end{array}$ & $\begin{array}{l}-0.003 \\
{[0.004]}\end{array}$ & $\begin{array}{c}-0.002 \\
{[0.001]}\end{array}$ & $\begin{array}{l}-0.005 \\
{[0.004]}\end{array}$ & $\begin{array}{l}-0.001 \\
{[0.001]}\end{array}$ & $\begin{array}{c}-0.008^{* *} \\
{[0.004]}\end{array}$ & $\begin{array}{c}-0.002 \\
{[0.001]}\end{array}$ & $\begin{array}{c}-0.020^{* *} \\
{[0.009]}\end{array}$ & $\begin{array}{l}-0.002 \\
{[0.001]}\end{array}$ & $\begin{array}{l}-0.009 \\
{[0.006]}\end{array}$ & $\begin{array}{c}-0.002 \\
{[0.001]}\end{array}$ & $\begin{array}{l}-0.013 \\
{[0.010]}\end{array}$ \\
\hline Constant & $\begin{array}{c}0.136 \\
{[0.183]}\end{array}$ & $\begin{array}{l}0.379 * \\
{[0.194]}\end{array}$ & $\begin{array}{l}0.276^{*} \\
{[0.149]}\end{array}$ & $\begin{array}{l}0.486^{*} \\
{[0.248]}\end{array}$ & $\begin{array}{c}0.287 \\
{[0.180]}\end{array}$ & $\begin{array}{c}0.249 \\
{[0.183]}\end{array}$ & $\begin{array}{c}0.292 * * \\
{[0.144]}\end{array}$ & $\begin{array}{l}0.440 * \\
{[0.263]}\end{array}$ & $\begin{array}{l}0.284 * \\
{[0.148]}\end{array}$ & $\begin{array}{l}0.463 * \\
{[0.272]}\end{array}$ & $\begin{array}{l}0.282^{*} \\
{[0.157]}\end{array}$ & $\begin{array}{l}0.537^{*} \\
{[0.292]}\end{array}$ \\
\hline Observations & 1,160 & 2,868 & 3,022 & 1,796 & 1,537 & 2,116 & 2,298 & 1,723 & 2,691 & 1,509 & 3,013 & 1,187 \\
\hline \# Countries & 14 & 35 & 44 & 38 & 13 & 18 & 20 & 18 & 21 & 20 & 29 & 12 \\
\hline Model $\chi^{2}$ & 436.09 & 332.26 & 428.58 & 295.39 & 397.03 & 429.32 & 442.99 & 256.35 & 579.06 & 179.66 & 574.04 & 139.48 \\
\hline$\chi^{2}(4): \Delta E$ & 2.14 & 0.96 & 6.90 & 1.86 & 4.79 & 7.34 & 7.02 & $8.66^{*}$ & 6.06 & 5.03 & 5.35 & 4.51 \\
\hline (p-value) & 0.71 & 0.92 & 0.14 & 0.76 & 0.31 & 0.12 & 0.14 & 0.07 & 0.20 & 0.28 & 0.25 & 0.34 \\
\hline$\chi^{2}(1): \Delta \mathrm{E}$ & 1.56 & 0.31 & $5.63 * *$ & 0.92 & $2.84^{*}$ & $3.56^{*}$ & $6.00 * *$ & $5.74 * *$ & $4.95 * *$ & 1.89 & $4.80 * *$ & 2.42 \\
\hline (p-value) & 0.21 & 0.58 & 0.02 & 0.34 & 0.09 & 0.06 & 0.01 & 0.02 & 0.03 & 0.17 & 0.03 & 0.12 \\
\hline Sum of Coef. & -0.01 & -0.01 & $-0.01 * *$ & -0.02 & $-0.01 *$ & $-0.03 *$ & $-0.01 * *$ & $-0.08 * *$ & $-0.01 * *$ & -0.03 & $-0.012 * *$ & -0.06 \\
\hline
\end{tabular}


Table 4. Market Timing (cont.)

Panel C. Changes in Debt

\begin{tabular}{|c|c|c|c|c|c|c|c|c|c|c|c|c|}
\hline Dependent V & \multicolumn{2}{|c|}{$\begin{array}{l}\text { Legal } \\
\text { Origin }\end{array}$} & \multicolumn{2}{|c|}{ Investment Profile } & \multicolumn{2}{|c|}{$\begin{array}{c}\text { Earnings Management } \\
\text { Smoothing }\end{array}$} & \multicolumn{2}{|c|}{$\begin{array}{c}\text { Big } 5 \\
\text { Auditors Presence }\end{array}$} & \multicolumn{2}{|c|}{$\begin{array}{l}\text { Number of } \\
\text { Analysts }\end{array}$} & \multicolumn{2}{|c|}{$\begin{array}{l}\text { Institutional } \\
\text { Investors }\end{array}$} \\
\hline & Common & Civil & Strong & Weak & Low & High & High & Low & High & Low & High & Low \\
\hline & 1 & 2 & 3 & 4 & 5 & 6 & 7 & 8 & 9 & 10 & 11 & 12 \\
\hline$\overline{R_{t-1}^{D}}$ & $\begin{array}{c}0.256^{* * * *} \\
{[0.041]}\end{array}$ & $\begin{array}{c}0.165 * * * \\
{[0.026]}\end{array}$ & $\begin{array}{c}0.244 * * * \\
{[0.021]}\end{array}$ & $\begin{array}{c}0.211 * * * \\
{[0.047]}\end{array}$ & $\begin{array}{c}0.233 * * * \\
{[0.027]}\end{array}$ & $\begin{array}{c}0.219 * * * \\
{[0.028]}\end{array}$ & $\begin{array}{c}0.224 * * * \\
{[0.022]}\end{array}$ & $\begin{array}{c}0.221 * * * \\
{[0.037]}\end{array}$ & $\begin{array}{c}0.233 * * * \\
{[0.023]}\end{array}$ & $\begin{array}{c}0.217 * * * \\
{[0.037]}\end{array}$ & $\begin{array}{c}0.316^{* * * *} \\
{[0.024]}\end{array}$ & $\begin{array}{c}0.147 * * * \\
{[0.032]}\end{array}$ \\
\hline$R_{t-2}^{D}$ & $\begin{array}{l}-0.044 \\
{[0.041]}\end{array}$ & $\begin{array}{c}0.054 * * \\
{[0.026]}\end{array}$ & $\begin{array}{c}0.115^{* * * *} \\
{[0.021]}\end{array}$ & $\begin{array}{l}-0.073 \\
{[0.047]}\end{array}$ & $\begin{array}{c}0.039 \\
{[0.027]}\end{array}$ & $\begin{array}{c}0.105 * * * \\
{[0.028]}\end{array}$ & $\begin{array}{l}0.043^{*} \\
{[0.022]}\end{array}$ & $\begin{array}{c}0.114 * * * \\
{[0.038]}\end{array}$ & $\begin{array}{c}0.103 * * * \\
{[0.022]}\end{array}$ & $\begin{array}{c}0.017 \\
{[0.037]}\end{array}$ & $\begin{array}{c}0.139 * * * \\
{[0.024]}\end{array}$ & $\begin{array}{l}-0.058^{*} \\
{[0.032]}\end{array}$ \\
\hline$R_{t-3}^{D}$ & $\begin{array}{c}-0.110^{* * * *} \\
{[0.042]}\end{array}$ & $\begin{array}{c}-0.137 * * * \\
{[0.025]}\end{array}$ & $\begin{array}{c}-0.205^{* * * *} \\
{[0.021]}\end{array}$ & $\begin{array}{c}-0.115^{* *} \\
{[0.047]}\end{array}$ & $\begin{array}{c}-0.188^{* * * *} \\
{[0.027]}\end{array}$ & $\begin{array}{c}-0.203 * * * \\
{[0.028]}\end{array}$ & $\begin{array}{c}-0.189 * * * \\
{[0.023]}\end{array}$ & $\begin{array}{c}-0.180 * * * \\
{[0.037]}\end{array}$ & $\begin{array}{c}-0.230 * * * * \\
{[0.023]}\end{array}$ & $\begin{array}{c}-0.135 * * * \\
{[0.037]}\end{array}$ & $\begin{array}{c}-0.301 * * * \\
{[0.025]}\end{array}$ & $\begin{array}{c}-0.110^{* * *} \\
{[0.030]}\end{array}$ \\
\hline $\mathrm{R}_{\mathrm{t}-4}^{\mathrm{D}}$ & $\begin{array}{l}-0.058 \\
{[0.042]}\end{array}$ & $\begin{array}{c}-0.102^{* * *} * \\
{[0.025]}\end{array}$ & $\begin{array}{l}-0.001 \\
{[0.021]}\end{array}$ & $\begin{array}{c}-0.125^{* * *} \\
{[0.048]}\end{array}$ & $\begin{array}{c}-0.056^{* *} \\
{[0.027]}\end{array}$ & $\begin{array}{l}-0.019 \\
{[0.028]}\end{array}$ & $\begin{array}{c}-0.053^{* *} \\
{[0.022]}\end{array}$ & $\begin{array}{l}-0.019 \\
{[0.037]}\end{array}$ & $\begin{array}{l}-0.006 \\
{[0.022]}\end{array}$ & $\begin{array}{c}-0.077 * * \\
{[0.037]}\end{array}$ & $\begin{array}{c}0.081 * * * \\
{[0.025]}\end{array}$ & $\begin{array}{c}-0.175^{* * *} \\
{[0.031]}\end{array}$ \\
\hline$\Delta \mathrm{D}_{\mathrm{t}-1}$ & $\begin{array}{c}0.000 \\
{[0.000]}\end{array}$ & $\begin{array}{c}0.000 \\
{[0.000]}\end{array}$ & $\begin{array}{l}0.000 * \\
{[0.000]}\end{array}$ & $\begin{array}{c}0.00 \\
{[0.000]}\end{array}$ & $\begin{array}{c}0.000 \\
{[0.000]}\end{array}$ & $\begin{array}{c}0.000 \\
{[0.000]}\end{array}$ & $\begin{array}{c}0.000 \\
{[0.000]}\end{array}$ & $\begin{array}{c}0.000 \\
{[0.001]}\end{array}$ & $\begin{array}{l}0.000 * \\
{[0.000]}\end{array}$ & $\begin{array}{c}0.001 \\
{[0.001]}\end{array}$ & $\begin{array}{c}0.000 \\
{[0.000]}\end{array}$ & $\begin{array}{c}0.000 \\
{[0.002]}\end{array}$ \\
\hline$\Delta D_{t-2}$ & $\begin{array}{c}0.000 \\
{[0.000]}\end{array}$ & $\begin{array}{c}0.000 \\
{[0.000]}\end{array}$ & $\begin{array}{c}0.00 \\
{[0.000]}\end{array}$ & $\begin{array}{c}0.001 * * \\
{[0.000]}\end{array}$ & $\begin{array}{c}0.000 \\
{[0.000]}\end{array}$ & $\begin{array}{c}0.000 \\
{[0.000]}\end{array}$ & $\begin{array}{c}0.000 \\
{[0.000]}\end{array}$ & $\begin{array}{c}0.003 \\
{[0.002]}\end{array}$ & $\begin{array}{l}0.000 * \\
{[0.000]}\end{array}$ & $\begin{array}{c}0.003 \\
{[0.002]}\end{array}$ & $\begin{array}{l}0.000 * \\
{[0.000]}\end{array}$ & $\begin{array}{c}0.001 \\
{[0.002]}\end{array}$ \\
\hline$\Delta \mathrm{D}_{\mathrm{t}-3}$ & $\begin{array}{c}0.000 \\
{[0.000]}\end{array}$ & $\begin{array}{c}0.000 \\
{[0.000]}\end{array}$ & $\begin{array}{l}0.000 * \\
{[0.000]}\end{array}$ & $\begin{array}{c}0.00 \\
{[0.000]}\end{array}$ & $\begin{array}{c}0.000 \\
{[0.000]}\end{array}$ & $\begin{array}{c}0.000 \\
{[0.000]}\end{array}$ & $\begin{array}{c}0.000 \\
{[0.000]}\end{array}$ & $\begin{array}{c}0.002 \\
{[0.002]}\end{array}$ & $\begin{array}{l}0.000 * \\
{[0.000]}\end{array}$ & $\begin{array}{c}0.003 \\
{[0.002]}\end{array}$ & $\begin{array}{l}0.000^{*} \\
{[0.000]}\end{array}$ & $\begin{array}{c}0.002 \\
{[0.002]}\end{array}$ \\
\hline$\Delta \mathrm{D}_{\mathrm{t}-4}$ & $\begin{array}{c}0.000 \\
{[0.000]}\end{array}$ & $\begin{array}{c}0.000 \\
{[0.000]}\end{array}$ & $\begin{array}{c}0.00 \\
{[0.000]}\end{array}$ & $\begin{array}{c}0.00 \\
{[0.000]}\end{array}$ & $\begin{array}{c}0.000 \\
{[0.000]}\end{array}$ & $\begin{array}{c}0.000 \\
{[0.000]}\end{array}$ & $\begin{array}{c}0.000 \\
{[0.000]}\end{array}$ & $\begin{array}{c}0.001 \\
{[0.001]}\end{array}$ & $\begin{array}{c}0.000 \\
{[0.000]}\end{array}$ & $\begin{array}{c}0.001 \\
{[0.001]}\end{array}$ & $\begin{array}{c}0.000 \\
{[0.000]}\end{array}$ & $\begin{array}{c}0.001 \\
{[0.002]}\end{array}$ \\
\hline Constant & $\begin{array}{l}-0.073^{*} \\
{[0.043]}\end{array}$ & $\begin{array}{c}-0.065^{* * * *} \\
{[0.021]}\end{array}$ & $\begin{array}{c}-0.062 * * * \\
{[0.014]}\end{array}$ & $\begin{array}{c}-0.115 * * \\
{[0.056]}\end{array}$ & $\begin{array}{c}-0.070 * * * \\
{[0.024]}\end{array}$ & $\begin{array}{c}-0.070 * * * \\
{[0.021]}\end{array}$ & $\begin{array}{c}-0.069 * * * \\
{[0.019]}\end{array}$ & $\begin{array}{c}-0.072 * * * \\
{[0.028]}\end{array}$ & $\begin{array}{c}-0.064 * * * * \\
{[0.016]}\end{array}$ & $\begin{array}{c}-0.080 * * \\
{[0.038]}\end{array}$ & $\begin{array}{c}-0.053 * * * \\
{[0.015]}\end{array}$ & $\begin{array}{c}-0.106^{* * * *} \\
{[0.035]}\end{array}$ \\
\hline Observations & 551 & 1,310 & 2,175 & 382 & 1,283 & 1,194 & 1,848 & 709 & 1,884 & 673 & 1,706 & 851 \\
\hline \# Countries & 8 & 15 & 23 & 16 & 11 & 11 & 16 & 7 & 15 & 8 & 14 & 9 \\
\hline Model $\chi^{2}$ & 69.54 & 114.49 & 302.62 & 57.58 & 178.14 & 142.56 & 239.31 & 86.42 & 276.85 & 72.32 & 372.76 & 91.92 \\
\hline$\chi^{2}(4): \Delta \mathrm{D}$ & 3.72 & 0.62 & 5.87 & 6.61 & 3.49 & 0.58 & 4.03 & 4.45 & 4.78 & 2.43 & 4.17 & 1.10 \\
\hline (p-value) & 0.44 & 0.96 & 0.21 & 0.16 & 0.48 & 0.97 & 0.40 & 0.35 & 0.31 & 0.66 & 0.38 & 0.89 \\
\hline$\chi^{2}(1): \Delta \mathrm{D}$ & 2.60 & 0.00 & 2.48 & 1.62 & 2.58 & 0.12 & $2.85^{*}$ & 1.64 & $3.78^{*}$ & 1.68 & $3.57 *$ & 0.34 \\
\hline (p-value) & 0.11 & 0.95 & 0.12 & 0.20 & 0.11 & 0.72 & 0.09 & 0.20 & 0.05 & 0.19 & 0.06 & 0.56 \\
\hline Sum of Coef. & 0.00 & 0.00 & 0.00 & 0.00 & 0.00 & 0.00 & $0.00 *$ & 0.01 & $0.00^{*}$ & 0.01 & $0.00 *$ & 0.00 \\
\hline
\end{tabular}


Table 5. Pseudo-market Timing

The following regression equation is specified:

$S_{t}=\alpha+\sum_{i=1}^{4} \beta_{i} R_{t-i}^{E}+\sum_{i=1}^{4} \gamma_{i} S_{t-i}+\varepsilon_{1 t}$, in Panel A,

where $R_{t}^{E}$ is the stock return for month $\mathrm{t}, \mathrm{S}_{\mathrm{t}}$ is the ratio of the (equity principal/(equity principal + debt principal)) in month t. Common/Civil Law countries refer to those countries with the respective legal origins. The investment profile indicates the level of general stability in business that is prevalent in a country. Earnings management smoothing (EMS) is an index from 2 (low smoothing) to 28.3 (high smoothing) of the level of earnings management occurs in a nation. Auditor Presence is an index from 1 (low) to 4 (high) indicating the percent of a nation's firms audited by the Big 5 accounting firms (i.e., quartiles). Analyst Presence is the number of analysts following a nation's largest 30 firms. Institutional Investor indicates the importance of institutional investors in a nation - proxied by the average of total assets in pooled investment, scaled by that nation's GDP. The $\chi^{2}(4)$ tests the null hypothesis that each lagged coefficient of $\mathrm{S}_{\mathrm{t}}$ is zero. The $\chi^{2}(1)$ tests the null hypothesis that the sum of lagged coefficients of $S_{t}$ is zero. Standard errors are given in brackets. *, **, *** indicate significance levels of 10, 5, and 1 percent, respectively. Shaded cells indicate evidence of significant test results.

Panel A. Equity Share

\begin{tabular}{|c|c|c|c|c|c|c|c|c|c|c|c|c|}
\hline \multicolumn{13}{|c|}{ Dependent Variable $=\mathrm{S}$} \\
\hline & \multicolumn{2}{|c|}{$\begin{array}{l}\text { Legal } \\
\text { Origin }\end{array}$} & \multicolumn{2}{|c|}{ Investment Profile } & \multicolumn{2}{|c|}{$\begin{array}{c}\text { Earnings Management } \\
\text { Smoothing }\end{array}$} & \multicolumn{2}{|c|}{$\begin{array}{c}\text { Big } 5 \\
\text { Auditors Presence }\end{array}$} & \multicolumn{2}{|c|}{$\begin{array}{c}\text { Number of } \\
\text { Analysts }\end{array}$} & \multicolumn{2}{|c|}{$\begin{array}{l}\text { Institutional } \\
\text { Investors }\end{array}$} \\
\hline & Common & Civil & Strong & Weak & Low & High & High & Low & High & Low & High & Low \\
\hline & 1 & 2 & 3 & 4 & 5 & 6 & 7 & 8 & 9 & 10 & 11 & 12 \\
\hline $\mathrm{R}_{\mathrm{t}-1}^{\mathrm{E}}$ & -0.001 & 0.001 & 0.002 & 0.002 & 0.004 & 0.000 & 0.000 & 0.001 & 0.003 & -0.002 & 0.002 & -0.001 \\
\hline & {$[0.003]$} & {$[0.002]$} & {$[0.002]$} & {$[0.002]$} & {$[0.003]$} & {$[0.003]$} & {$[0.002]$} & {$[0.002]$} & {$[0.002]$} & {$[0.003]$} & {$[0.002]$} & {$[0.003]$} \\
\hline $\mathrm{R}_{\mathrm{t}-2}^{\mathrm{E}}$ & 0.001 & -0.001 & 0.000 & -0.003 & 0.000 & 0.002 & 0.003 & -0.002 & -0.001 & 0.000 & -0.002 & 0.003 \\
\hline & {$[0.003]$} & {$[0.002]$} & {$[0.002]$} & {$[0.002]$} & {$[0.003]$} & [0.003] & {$[0.003]$} & {$[0.003]$} & {$[0.002]$} & {$[0.003]$} & {$[0.002]$} & {$[0.003]$} \\
\hline $\mathrm{R}_{\mathrm{t}-\mathrm{3}}^{\mathrm{E}}$ & -0.002 & 0.002 & $0.004 *$ & -0.001 & $0.004 *$ & 0.001 & 0.002 & 0.003 & -0.004 & $0.008 * * *$ & 0.001 & 0.004 \\
\hline & {$[0.003]$} & {$[0.002]$} & {$[0.002]$} & {$[0.002]$} & {$[0.003]$} & {$[0.003]$} & [0.003] & {$[0.003]$} & {$[0.002]$} & {$[0.003]$} & {$[0.002]$} & {$[0.003]$} \\
\hline $\mathrm{R}_{\mathrm{t}-4}^{\mathrm{E}}$ & 0.002 & 0.001 & 0.002 & 0.002 & -0.002 & 0.002 & 0.000 & -0.002 & $0.005^{* *}$ & -0.004 & 0.001 & -0.001 \\
\hline & [0.003] & [0.002] & [0.002] & [0.002] & [0.003] & [0.003] & [0.002] & [0.003] & {$[0.002]$} & [0.003] & [0.002] & [0.003] \\
\hline $\mathrm{S}_{\mathrm{t}-1}$ & $-0.127 * * *$ & $-0.091 * * *$ & $-0.085^{* * *} *$ & $-0.129 * * *$ & $-0.095^{* * *}$ & $-0.086^{* * *}$ & $-0.109 * * *$ & $-0.080 * * *$ & $-0.041 * *$ & $-0.148 * * *$ & $-0.094 * * *$ & $-0.106^{* * *}$ \\
\hline & {$[0.028]$} & {$[0.020]$} & [0.018] & {$[0.023]$} & {$[0.025]$} & [0.021] & {$[0.020]$} & [0.024] & [0.019] & {$[0.025]$} & [0.018] & [0.027] \\
\hline $\mathrm{S}_{\mathrm{t}-2}$ & $0.108 * * *$ & $0.122 * * *$ & $0.121 * * *$ & $0.137 * * *$ & $0.130 * * *$ & $0.124 * * *$ & $0.129 * * *$ & $0.103 * * *$ & $0.114 * * *$ & $0.119 * * *$ & $0.094 * * *$ & $0.157 * * *$ \\
\hline & [0.028] & [0.020] & [0.017] & [0.023] & [0.024] & [0.021] & [0.020] & [0.024] & [0.019] & [0.025] & [0.018] & [0.027] \\
\hline $\mathrm{S}_{\mathrm{t}-3}$ & $0.238 * * *$ & $0.191 * * *$ & $0.185^{* * *}$ & $0.230 * * *$ & $0.253 * * *$ & $0.177 * * *$ & $0.232 * * *$ & $0.180 * * *$ & $0.231 * * *$ & $0.178 * * *$ & $0.184 * * *$ & $0.252 * * *$ \\
\hline & [0.027] & [0.020] & [0.017] & [0.023] & [0.024] & [0.021] & [0.019] & [0.023] & [0.018] & [0.025] & [0.018] & [0.027] \\
\hline $\mathrm{S}_{\mathrm{t}-4}$ & $0.201 * * *$ & $0.147 * * *$ & $0.174 * * *$ & $0.164 * * *$ & $0.188 * * *$ & $0.155^{* * *} *$ & $0.177 * * *$ & $0.163 * * *$ & $0.140 * * *$ & $0.216^{* * *} *$ & $0.150 * * *$ & $0.211 * * *$ \\
\hline & [0.028] & [0.020] & [0.017] & [0.024] & {$[0.025]$} & {$[0.021]$} & [0.020] & [0.024] & [0.019] & [0.025] & [0.018] & [0.027] \\
\hline Constant & $0.389 * * *$ & 0.331 *** & $0.436^{* * *}$ & $0.303^{* * *}$ & $0.408 * * *$ & $0.395 * * *$ & $0.439 * * *$ & $0.343 * * *$ & $0.368^{* * *}$ & $0.385^{* * * *}$ & $0.405 * * *$ & $0.345^{* * *}$ \\
\hline & [0.050] & [0.032] & [0.030] & [0.033] & [0.042] & [0.035] & [0.035] & [0.037] & [0.031] & [0.043] & {$[0.031]$} & [0.044] \\
\hline Observations & 1,158 & 2,364 & 3,019 & 1,792 & 1,536 & 2,116 & 2,297 & 1,722 & 2,691 & 1,505 & 3,010 & 1,186 \\
\hline \# Countries & 14 & 26 & 43 & 38 & 13 & 18 & 20 & 18 & 21 & 19 & 28 & 12 \\
\hline Model $\chi^{2}$ & 143.02 & 192.58 & 276.55 & 201.47 & 196.48 & 172.55 & 268.93 & 133.12 & 273.04 & 174.87 & 212.7 & 191.84 \\
\hline$\chi^{2}(4): R^{E}$ & 0.87 & 1.32 & $8.53^{*}$ & 2.70 & 6.90 & 2.33 & 2.97 & 2.22 & 6.35 & $10.32 * *$ & 1.56 & 4.88 \\
\hline (p-value) & 0.93 & 0.86 & 0.07 & 0.61 & 0.14 & 0.67 & 0.56 & 0.70 & 0.17 & 0.04 & 0.82 & 0.30 \\
\hline$\chi^{2}(1): R^{E}$ & 0.01 & 0.50 & $6.86^{* * * *}$ & 0.04 & $3.06^{*}$ & 1.70 & 1.60 & 0.00 & 1.37 & 0.46 & 0.50 & 1.35 \\
\hline (p-value) & 0.91 & 0.48 & 0.00 & 0.84 & 0.08 & 0.19 & 0.21 & 0.95 & 0.24 & 0.50 & 0.48 & 0.24 \\
\hline Sum of Coef. & -0.00 & 0.00 & $0.01 * * *$ & 0.00 & $0.01 * *$ & 0.00 & 0.00 & -0.00 & 0.00 & 0.00 & 0.00 & 0.01 \\
\hline
\end{tabular}


Table 5. Pseudo-market Timing (cont.)

Panel B. Change in Equity

\begin{tabular}{|c|c|c|c|c|c|c|c|c|c|c|c|c|}
\hline \multicolumn{13}{|c|}{ Dependent Variable $=\Delta \mathbf{E}$} \\
\hline & \multicolumn{2}{|c|}{$\begin{array}{c}\text { Legal } \\
\text { Origin }\end{array}$} & \multicolumn{2}{|c|}{ Investment Profile } & \multicolumn{2}{|c|}{$\begin{array}{c}\text { Earnings Management } \\
\text { Smoothing }\end{array}$} & \multicolumn{2}{|c|}{$\begin{array}{c}\text { Big } 5 \\
\text { Auditors Presence }\end{array}$} & \multicolumn{2}{|c|}{$\begin{array}{c}\text { Number of } \\
\text { Analysts }\end{array}$} & \multicolumn{2}{|c|}{$\begin{array}{l}\text { Institutional } \\
\text { Investors }\end{array}$} \\
\hline & Common & Civil & Strong & Weak & Low & High & High & Low & High & Low & High & Low \\
\hline & 1 & 2 & 3 & 4 & 5 & 6 & 7 & 8 & 9 & 10 & 11 & 12 \\
\hline \multirow[t]{2}{*}{$\mathrm{R}_{\mathrm{t}-1}^{\mathrm{E}}$} & $1.304 * * *$ & $0.176^{* * *}$ & $0.453^{* *}$ & $0.386 * * *$ & $1.154 * * *$ & $0.251^{* * *}$ & 0.897 **** & 0.048 & $0.574 * * *$ & 0.06 & $0.474 * *$ & 0.096 \\
\hline & [0.466] & [0.089] & [0.184] & [0.112] & [0.392] & [0.113] & [0.302] & {$[0.056]$} & [0.218] & [0.091] & [0.191] & {$[0.071]$} \\
\hline \multirow[t]{2}{*}{$\mathrm{R}_{\mathrm{t}-2}^{\mathrm{E}}$} & 0.755 & 0.149 & $0.521 * * *$ & 0.002 & 0.625 & $0.369^{* * *}$ & $0.776^{* * *}$ & $0.156^{* *}$ & $0.463^{*}$ & $0.208^{* *}$ & $0.499^{* *}$ & 0.073 \\
\hline & [0.496] & {$[0.095]$} & [0.197] & {$[0.130]$} & [0.433] & [0.122] & {$[0.334]$} & {$[0.061]$} & [0.239] & [0.099] & {$[0.205]$} & {$[0.078]$} \\
\hline \multirow[t]{2}{*}{$R_{t-3}^{E}$} & -0.308 & 0.113 & 0.020 & 0.175 & -0.083 & 0.029 & -0.124 & -0.033 & -0.108 & -0.028 & -0.102 & 0.038 \\
\hline & [0.499] & {$[0.097]$} & [0.198] & {$[0.132]$} & {$[0.435]$} & {$[0.125]$} & [0.337] & {$[0.062]$} & {$[0.243]$} & {$[0.100]$} & [0.207] & {$[0.080]$} \\
\hline \multirow[t]{2}{*}{$\mathrm{R}_{\mathrm{t}-4}^{\mathrm{E}}$} & 0.143 & 0.08 & 0.070 & 0.018 & 0.21 & 0.138 & 0.239 & 0.095 & 0.246 & 0.034 & 0.178 & 0.104 \\
\hline & [0.484] & [0.092] & [0.187] & [0.118] & [0.403] & [0.118] & [0.313] & [0.058] & [0.227] & [0.092] & [0.195] & [0.073] \\
\hline \multirow[t]{2}{*}{$\Delta \mathrm{E}_{\mathrm{t}-1}$} & $-0.603 * * *$ & $-0.910 * * *$ & $-0.686 * * *$ & $-0.716^{* * *}$ & $-0.654 * * *$ & $-0.882 * * *$ & $-0.689 * * *$ & $-0.855^{* * *}$ & $-0.692 * * *$ & $-0.703 * * *$ & $-0.689 * * *$ & $-0.872 * * *$ \\
\hline & [0.029] & [0.019] & [0.018] & [0.024] & [0.025] & [0.020] & [0.020] & [0.024] & [0.019] & [0.027] & [0.018] & [0.029] \\
\hline \multirow[t]{2}{*}{$\Delta \mathrm{E}_{\mathrm{t}-2}$} & $-0.576 * * *$ & $-0.734 * * *$ & $-0.597 * * *$ & $-0.632 * * *$ & $-0.597 * * *$ & $-0.685 * * *$ & $-0.612 * * *$ & $-0.685 * * *$ & $-0.613 * * *$ & $-0.562 * * *$ & $-0.609 * * *$ & $-0.726 * * *$ \\
\hline & [0.032] & [0.025] & [0.021] & [0.027] & [0.029] & [0.026] & [0.024] & [0.030] & [0.022] & [0.031] & [0.021] & [0.035] \\
\hline \multirow[t]{2}{*}{$\Delta \mathrm{E}_{\mathrm{t}-3}$} & $-0.323 * * *$ & $-0.424 * * *$ & $-0.354 * * *$ & $-0.404 * * *$ & $-0.355 * * *$ & $-0.397 * * *$ & $-0.366 * * *$ & $-0.418 * * *$ & $-0.364 * * *$ & $-0.390 * * *$ & $-0.364 * * *$ & $-0.425 * * *$ \\
\hline & [0.032] & [0.025] & [0.020] & [0.027] & [0.028] & [0.026] & [0.023] & [0.030] & [0.021] & {$[0.030]$} & [0.020] & {$[0.035]$} \\
\hline \multirow[t]{2}{*}{$\Delta \mathrm{E}_{\mathrm{t}-1}$} & $-0.138 * * *$ & $-0.187 * * *$ & $-0.129 * * *$ & $-0.283 * * *$ & $-0.144 * * *$ & $-0.178 * * *$ & $-0.152 * * *$ & $-0.193 * * *$ & $-0.146 * * *$ & $-0.261 * * *$ & $-0.153 * * *$ & $-0.172 * * *$ \\
\hline & {$[0.027]$} & [0.019] & [0.017] & [0.025] & [0.024] & [0.020] & [0.019] & [0.024] & {$[0.018]$} & {$[0.026]$} & [0.017] & {$[0.029]$} \\
\hline \multirow[t]{2}{*}{ Constant } & -1.352 & -0.502 & -1.157 & -0.023 & -2.044 & -0.316 & -1.724 & -0.036 & -1.394 & -0.025 & -1.163 & -0.045 \\
\hline & [2.065] & {$[0.521]$} & [0.892] & {$[0.563]$} & [1.656] & {$[0.622]$} & [1.218] & [0.308] & [1.037] & {$[0.436]$} & [0.937] & {$[0.348]$} \\
\hline Observations & 1,157 & 2,362 & 3016 & 1790 & 1,535 & 2,116 & 2,296 & 1,721 & 2,691 & 1,503 & 3,009 & 1,185 \\
\hline \# Countries & 14 & 26 & 43 & 38 & 13 & 18 & 20 & 18 & 21 & 19 & 28 & 12 \\
\hline Model $\chi^{2}$ & 533.75 & 2274.37 & 1650.42 & 1012.22 & 766.92 & 1908.43 & 1244.48 & 1336.06 & 1484.39 & 733.27 & 1625.19 & 935.34 \\
\hline$\chi^{2}(4): R^{E}$ & $17.84 * * *$ & $18.11^{* * *}$ & $24.83 * * *$ & $23.38 * * *$ & $20.14 * * *$ & $30.60 * * *$ & $28.54 * * *$ & $15.56 * * *$ & $21.30^{* * *}$ & $8.47 *$ & $22.76 * * *$ & $10.44 * *$ \\
\hline (p-value) & 0.00 & 0.00 & 0.00 & 0.00 & 0.00 & 0.00 & 0.00 & 0.00 & 0.00 & 0.08 & 0.00 & 0.03 \\
\hline$\chi^{2}(1): R^{E}$ & $8.86^{* * * *}$ & $15.66^{* * *}$ & $16.76^{* * *}$ & $16.27 * * *$ & $12.93 * * *$ & $23.47 * * *$ & 18.96 *** & $11.62 * * *$ & $15.56^{* * *}$ & $4.98 * *$ & $15.57 * * *$ & $10.27 * * *$ \\
\hline (p-value) & 0.00 & 0.00 & 0.00 & 0.00 & 0.00 & 0.00 & 0.00 & 0.00 & 0.00 & 0.02 & 0.00 & 0.00 \\
\hline Sum of Coef. & $1.89 * * *$ & $0.52 * * *$ & $1.06^{* * * *}$ & $0.58 * * *$ & $1.91 * * *$ & $0.79 * * *$ & $1.79 * * *$ & $0.27 * * *$ & $1.17 * * *$ & $0.27 * *$ & $1.05^{* * * *}$ & $0.31 * * *$ \\
\hline
\end{tabular}


Table 5. Pseudo-market Timing (cont.)

Panel C. Change in Debt

\begin{tabular}{|c|c|c|c|c|c|c|c|c|c|c|c|c|}
\hline \multicolumn{13}{|c|}{ Dependent Variable $=\Delta D$} \\
\hline & \multicolumn{2}{|c|}{$\begin{array}{l}\text { Legal } \\
\text { Origin }\end{array}$} & \multicolumn{2}{|c|}{ Investment Profile } & \multicolumn{2}{|c|}{$\begin{array}{l}\text { Earnings Management } \\
\text { Smoothing }\end{array}$} & \multicolumn{2}{|c|}{$\begin{array}{c}\text { Big } 5 \\
\text { Auditors Presence }\end{array}$} & \multicolumn{2}{|c|}{$\begin{array}{l}\text { Number of } \\
\text { Analysts }\end{array}$} & \multicolumn{2}{|c|}{$\begin{array}{l}\text { Institutional } \\
\text { Investors }\end{array}$} \\
\hline & Common & Civil & Strong & Weak & Low & High & High & Low & High & Low & High & Low \\
\hline & 1 & 2 & 3 & 4 & 5 & 6 & 7 & 8 & 9 & 10 & 11 & 12 \\
\hline $\mathrm{R}_{\mathrm{t}-1}^{\mathrm{D}}$ & -0.014 & $-0.026^{*}$ & $-0.019 *$ & -0.029 & -0.014 & $-0.028 * *$ & -0.016 & $-0.024 * *$ & $-0.028 * *$ & -0.007 & $-0.028^{*}$ & $-0.016^{* * *}$ \\
\hline & {$[0.023]$} & {$[0.015]$} & {$[0.011]$} & {$[0.020]$} & {$[0.014]$} & {$[0.013]$} & {$[0.012]$} & {$[0.011]$} & {$[0.014]$} & {$[0.008]$} & {$[0.015]$} & {$[0.006]$} \\
\hline $\mathrm{R}_{\mathrm{t}-2}^{\mathrm{D}}$ & $-0.071 * * *$ & 0.024 & -0.013 & 0.011 & $-0.034 * *$ & 0.018 & -0.02 & -0.001 & -0.009 & -0.012 & -0.026 & 0.005 \\
\hline & [0.027] & [0.017] & [0.014] & [0.024] & {$[0.017]$} & {$[0.015]$} & [0.016] & {$[0.011]$} & [0.017] & [0.009] & [0.019] & {$[0.006]$} \\
\hline $\mathrm{R}_{\mathrm{t}-3}^{\mathrm{D}}$ & 0.043 & -0.022 & 0.017 & -0.023 & 0.027 & -0.013 & 0.006 & 0.014 & 0.007 & -0.006 & $0.033^{*}$ & $-0.011^{*}$ \\
\hline & [0.027] & [0.017] & [0.014] & [0.024] & [0.017] & {$[0.015]$} & {$[0.016]$} & [0.011] & [0.018] & [0.009] & {$[0.020]$} & {$[0.006]$} \\
\hline$R_{t-4}^{D^{2}}$ & -0.025 & 0.012 & -0.011 & 0.024 & -0.019 & 0.014 & -0.003 & 0.008 & -0.012 & $0.019 * *$ & -0.017 & -0.001 \\
\hline & {$[0.023]$} & [0.015] & {$[0.011]$} & {$[0.020]$} & [0.014] & [0.013] & [0.013] & [0.011] & {$[0.014]$} & {$[0.008]$} & {$[0.016]$} & [0.006] \\
\hline$\Delta \mathrm{D}_{\mathrm{t}-1}$ & $-0.000 * * *$ & $-0.003 * * *$ & $-0.000 * * *$ & $-0.001 * * *$ & $-0.000 * * *$ & $-0.003 * * *$ & $-0.000 * * *$ & $-0.009 * * *$ & $-0.000 * * *$ & $-0.009 * * *$ & $-0.000 * * *$ & $-0.009^{* * *}$ \\
\hline & {$[0.000]$} & {$[0.000]$} & [0.000] & {$[0.000]$} & [0.000] & {$[0.000]$} & [0.000] & {$[0.000]$} & {$[0.000]$} & {$[0.000]$} & {$[0.000]$} & {$[0.000]$} \\
\hline$\Delta \mathrm{D}_{\mathrm{t}-2}$ & $-0.000 * * *$ & $-0.002 * * *$ & $-0.000 * * *$ & 0.000 & $-0.000^{* * *}$ & $-0.002 * * *$ & $-0.000^{* * *}$ & $-0.006^{* * *}$ & $-0.000 * * *$ & $-0.007 * * *$ & $-0.000 * * *$ & $-0.005^{* * *}$ \\
\hline & {$[0.000]$} & [0.000] & {$[0.000]$} & {$[0.000]$} & {$[0.000]$} & {$[0.000]$} & [0.000] & [0.000] & {$[0.000]$} & [0.000] & {$[0.000]$} & [0.000] \\
\hline$\Delta \mathrm{D}_{\mathrm{t}-3}$ & $-0.000^{*}$ & $-0.001 * * *$ & $-0.000^{* *}$ & $0.000^{* *}$ & $-0.000^{*}$ & $-0.001 * * *$ & 0.000 & $-0.004 * * *$ & 0.000 & $-0.003 * * *$ & 0.000 & $-0.004 * * *$ \\
\hline & {$[0.000]$} & {$[0.000]$} & {$[0.000]$} & {$[0.000]$} & {$[0.000]$} & {$[0.000]$} & {$[0.000]$} & {$[0.000]$} & [0.000] & {$[0.000]$} & [0.000] & [0.000] \\
\hline$\Delta \mathrm{D}_{\mathrm{t}-1}$ & 0.000 & 0.000 & 0.000 & $-0.000^{* *}$ & 0.000 & 0.000 & 0.000 & $-0.002 * * *$ & 0.000 & $-0.001 * * *$ & 0.000 & $-0.002 * * *$ \\
\hline & {$[0.000]$} & {$[0.000]$} & {$[0.000]$} & {$[0.000]$} & {$[0.000]$} & {$[0.000]$} & {$[0.000]$} & {$[0.000]$} & {$[0.000]$} & {$[0.000]$} & {$[0.000]$} & [0.000] \\
\hline Constant & -0.019 & -0.006 & $-0.009^{* *}$ & -0.01 & -0.013 & -0.006 & $-0.012 * *$ & -0.005 & $-0.013 * *$ & -0.004 & $-0.013^{* *}$ & -0.005 \\
\hline & [0.014] & [0.005] & {$[0.005]$} & [0.009] & [0.008] & [0.004] & {$[0.006]$} & [0.005] & {$[0.006]$} & {$[0.005]$} & [0.007] & {$[0.004]$} \\
\hline Observations & 556 & 1,093 & 2189 & 385 & 1,292 & 1,201 & 1,860 & 714 & 1,897 & 677 & 1,715 & 859 \\
\hline \# Countries & 8 & 11 & 23 & 16 & 11 & 11 & 16 & 7 & 15 & 8 & 14 & 9 \\
\hline Model $\chi^{2}$ & 137.73 & 450.36 & 214.01 & 91.24 & 181.25 & 506.47 & 207.27 & 754.49 & 207.86 & 720.93 & 189.31 & 850.91 \\
\hline$\chi^{2}(4): R^{D}$ & $12.99 * *$ & 5.12 & $9.42 *$ & 4.82 & $12.44 * *$ & 7.10 & $12.32 * *$ & 7.36 & $11.17 * *$ & $11.08 * *$ & $13.28 * *$ & $11.64 * *$ \\
\hline (p-value) & 0.01 & 0.28 & 0.05 & 0.31 & 0.01 & 0.13 & 0.02 & 0.12 & 0.02 & 0.03 & 0.01 & 0.02 \\
\hline$\chi^{2}(1): \mathrm{R}^{\mathrm{D}}$ & $5.62 * *$ & 0.65 & $5.11^{* *}$ & 0.45 & $6.99 * * *$ & 0.49 & $6.68^{* * *}$ & 0.54 & $8.56^{* * *}$ & 0.28 & $6.01 * *$ & $6.77 * *$ \\
\hline (p-value) & 0.02 & 0.42 & 0.02 & 0.50 & 0.00 & 0.48 & 0.00 & 0.46 & 0.00 & 0.59 & 0.01 & 0.01 \\
\hline Sum of Coef. & $-0.07 * *$ & -0.01 & $-0.03 * *$ & -0.02 & $-0.04 * * *$ & -0.01 & $-0.03 * *$ & -0.01 & $-0.04 * * *$ & -0.01 & $-0.04 * *$ & $-0.02 * *$ \\
\hline
\end{tabular}




\section{Table 6. Robustness Tests}

The following regression equation is specified:

$R_{t}^{E}=\alpha+\sum_{i=1}^{m} \beta_{i} R_{t-i}^{E}+\sum_{i=1}^{m} \gamma_{i} S_{t-i}+\varepsilon_{1 t}, \quad R_{t}^{E}=\alpha+\sum_{i=1}^{m} \beta_{i} R_{t-i}^{E}+\sum_{i=1}^{m} \gamma_{i} \Delta E_{t-i}+\varepsilon_{2 t}, \quad R_{t}^{D}=\alpha+\sum_{i=1}^{m} \beta_{i} R_{t-i}^{D}+\sum_{i=1}^{m} \gamma_{i} \Delta D_{t-i}+\varepsilon_{3 t}$,

in market timing specifications, and

$S_{t}=\alpha+\sum_{i=1}^{m} \beta_{i} R_{t-i}^{E}+\sum_{i=1}^{m} \gamma_{i} S_{t-i}+\varepsilon_{1 t}, \quad \Delta E_{t}=\alpha+\sum_{i=1}^{m} \beta_{i} R_{t-i}^{E}+\sum_{i=1}^{m} \gamma_{i} \Delta E_{t-i}+\varepsilon_{2 t}, \quad \Delta D_{t}=\alpha+\sum_{i=1}^{m} \beta_{i} R_{t-i}^{D}+\sum_{i=1}^{m} \delta_{i} \Delta D_{t-i}+\varepsilon_{3 t}$

in pseudo-market timing specifications,

where $R_{t}^{E}\left(R_{t}^{D}\right)$ is the stock return (interest rate swap rate) for month $\mathrm{t}, \mathrm{S}_{\mathrm{t}}$ is the ratio of the (equity principal/(equity principal + debt principal)) in month t. $\Delta \mathrm{E}_{\mathrm{t}}\left(\Delta \mathrm{D}_{\mathrm{t}}\right)$ is the log difference between the firm's principal raised through equity (debt) issuance in quarter $\mathrm{t}$ and $\mathrm{t}-1$. Common/Civil Law countries refer to those countries with the respective legal origins. The investment profile indicates the level of general stability in business that is prevalent in a country. Earnings management smoothing (EMS) is an index from 2 (low smoothing) to 28.3 (high smoothing) of the level of earnings management occurs in a nation. Auditor Presence is an index from 1 (low) to 4 (high) indicating the percent of a nation's firms audited by the Big 5 accounting firms (i.e., quartiles). Analyst Presence is the number of analysts following a nation's largest 30 firms. Institutional Investor indicates the importance of institutional investors in a nation - proxied by the average of total assets in pooled investment, scaled by that nation's GDP. The $\chi^{2}(4)$ tests the null hypothesis that each lagged coefficient of $S_{t}\left(\Delta E_{t} / \Delta D_{t}\right)$ is zero. The $\chi^{2}(1)$ tests the null hypothesis that the sum of lagged coefficients of $S_{t}\left(\Delta E_{t} / \Delta D_{t}\right)$ is zero. Standard errors are given in brackets. *,**,** indicate significance levels of 10,5, and 1 percent, respectively. Shaded cells indicate evidence of Granger Causality. Non-shaded outlined cells indicated reduced significance from the base analysis. Darker shaded cells indicate evidence of significant test results where there was none in the base analysis. Panel A excludes Australia. Panel B excludes domestic issuances with simultaneous international issuances. Panel C examines IPOs only. Panel D examines SEOs only.

Panel A. Excluding Australia

\begin{tabular}{|c|c|c|c|c|c|c|c|c|c|c|c|c|}
\hline & \multicolumn{2}{|c|}{$\begin{array}{l}\text { Legal } \\
\text { Origin }\end{array}$} & \multicolumn{2}{|c|}{ Investment Profile } & \multicolumn{2}{|c|}{$\begin{array}{c}\text { Earnings Management } \\
\text { Smoothing }\end{array}$} & \multicolumn{2}{|c|}{$\begin{array}{c}\text { Big } 5 \\
\text { Auditors Presence }\end{array}$} & \multicolumn{2}{|c|}{$\begin{array}{c}\text { Number of } \\
\text { Analysts }\end{array}$} & \multicolumn{2}{|c|}{$\begin{array}{l}\text { Institutional } \\
\text { Investors }\end{array}$} \\
\hline & Common & Civil & Strong & Weak & Low & High & High & Low & High & Low & High & Low \\
\hline & 1 & 2 & 3 & 4 & 5 & 6 & 7 & 8 & 9 & 10 & 11 & 12 \\
\hline \multicolumn{13}{|l|}{ Market Timing } \\
\hline$\chi^{2}(4): S \rightarrow R^{E}$ & 2.09 & $11.75^{* *}$ & 7.55 & $11.07 * *$ & $10.45^{* *}$ & $12.63 * *$ & 3.43 & $15.76 * * *$ & 7.78 & $10.88^{* *}$ & 7.20 & $14.59^{* * *}$ \\
\hline (p-value) & 0.72 & 0.02 & 0.11 & 0.03 & 0.03 & 0.01 & 0.49 & 0.00 & 0.10 & 0.03 & 0.13 & 0.01 \\
\hline$\chi^{2}(1): S \rightarrow R^{E}$ & 0.33 & $9.30^{* * *}$ & $3.89 * *$ & $4.82 * *$ & 2.04 & $4.65^{* *}$ & 2.47 & $5.89 * *$ & $5.12 * *$ & $5.41 * *$ & $3.65^{*}$ & $10.32^{* * * *}$ \\
\hline (p-value) & 0.56 & 0.00 & 0.04 & 0.03 & 0.15 & 0.03 & 0.12 & 0.02 & 0.02 & 0.02 & 0.06 & 0.00 \\
\hline Sum of Coef. & -027 & $-1.24 * * *$ & $-0.67 * *$ & $-1.16 * *$ & -0.69 & $-0.85 * *$ & -0.56 & $-1.26 * *$ & $-0.74 * *$ & $-1.34 * *$ & $-0.65 *$ & $-2.04 * * *$ \\
\hline$\chi^{2}(4): \Delta E \rightarrow R^{E}$ & 2.11 & 2.79 & 6.43 & 1.51 & 4.55 & 7.34 & 6.68 & $8.65^{*}$ & 6.05 & $15.11 * * *$ & 5.20 & 4.49 \\
\hline (p-value) & 0.72 & 0.59 & 0.17 & 0.82 & 0.34 & 0.12 & 0.15 & 0.07 & 0.20 & 0.00 & 0.27 & 0.34 \\
\hline$\chi^{2}(1): \Delta \mathrm{E} \rightarrow \mathrm{R}^{\mathrm{E}}$ & 1.62 & 0.46 & $5.47 * *$ & 0.85 & 2.66 & $3.56^{*}$ & $5.72 * *$ & $5.74 * *$ & $4.95^{* *}$ & $2.74^{*}$ & $4.64 * *$ & 2.42 \\
\hline (p-value) & 0.20 & 0.50 & 0.02 & 0.36 & 0.10 & 0.06 & 0.02 & 0.02 & 0.03 & 0.09 & 0.03 & 0.12 \\
\hline Sum of Coef. & -0.01 & -0.01 & $-0.014 * *$ & -0.02 & -0.01 & $-0.03 *$ & $-0.01 * *$ & $-0.08 * *$ & $-0.01 * *$ & $-0.08 *$ & $-0.01 * *$ & -0.06 \\
\hline$\chi^{2}(4): \Delta \mathrm{D} \rightarrow \mathrm{R}^{\mathrm{D}}$ & 4.58 & 0.62 & 5.79 & 7.28 & 4.07 & 0.58 & 4.60 & 4.45 & 4.78 & 3.91 & 4.93 & 1.10 \\
\hline (p-value) & 0.33 & 0.96 & 0.22 & 0.12 & 0.40 & 0.97 & 0.33 & 0.35 & 0.31 & 0.42 & 0.29 & 0.89 \\
\hline$\chi^{2}(1): \Delta \mathrm{D} \rightarrow \mathrm{R}^{\mathrm{D}}$ & $3.15^{*}$ & 0.00 & 2.32 & 2.24 & $2.96^{*}$ & 0.12 & $3.20 *$ & 1.64 & $3.78^{*}$ & 2.15 & $4.20 * *$ & 0.34 \\
\hline (p-value) & 0.08 & 0.95 & 0.13 & 0.13 & 0.09 & 0.72 & 0.07 & 0.20 & 0.05 & 0.14 & 0.04 & 0.56 \\
\hline Sum of Coef. & $0.00 *$ & 0.00 & 0.00 & 0.00 & $0.00^{*}$ & 0.00 & $0.00 *$ & 0.01 & $0.00^{*}$ & 0.01 & $0.00 * *$ & 0.00 \\
\hline
\end{tabular}


Table 6. Robustness Tests (cont.)

\begin{tabular}{|c|c|c|c|c|c|c|c|c|c|c|c|c|}
\hline \multicolumn{13}{|c|}{ Pseudo Market Timing } \\
\hline$\overline{\chi^{2}(4): R^{E} \rightarrow S}$ & 0.85 & 1.46 & 7.77 & 2.27 & 5.61 & 2.73 & 2.46 & 2.33 & 5.53 & $9.71 * *$ & 1.50 & 4.71 \\
\hline (p-value) & 0.93 & 0.83 & 0.10 & 0.69 & 0.23 & 0.60 & 0.65 & 0.68 & 0.24 & 0.04 & 0.83 & 0.32 \\
\hline$\chi^{2}(1): R^{E} \rightarrow S$ & 0.00 & 0.14 & $5.96 * *$ & 0.00 & 2.13 & 1.99 & 1.05 & 0.00 & 0.59 & 0.50 & 0.21 & 1.12 \\
\hline (p-value) & 0.95 & 0.71 & 0.01 & 0.98 & 0.14 & 0.16 & 0.31 & 0.96 & 0.44 & 0.48 & 0.64 & 0.29 \\
\hline Sum of Coef. & -0.00 & 0.00 & $0.01 * *$ & 0.00 & 0.01 & 0.00 & 0.00 & -0.00 & 0.00 & 0.00 & 0.00 & 0.00 \\
\hline$\chi^{2}(4): R^{E} \rightarrow \Delta E$ & $14.72 * * *$ & $18.33^{* * * *}$ & $20.12 * * *$ & $25.38 * * *$ & $16.08^{* * * *}$ & $32.95 * * *$ & $24.47 * * *$ & $15.27 * * *$ & $21.51 * * *$ & $14.39 * * *$ & $20.05^{* * *}$ & $11.66^{* *}$ \\
\hline (p-value) & 0.00 & 0.00 & 0.00 & 0.00 & 0.00 & 0.00 & 0.00 & 0.00 & 0.00 & 0.00 & 0.00 & 0.02 \\
\hline$\chi^{2}(1): R^{E} \rightarrow \Delta E$ & $6.57 * *$ & $15.89 * * *$ & $13.76^{* * *}$ & $17.44 * * *$ & $9.78^{* * * *}$ & $24.96^{* * *}$ & $15.49 * * *$ & $11.27 * * *$ & $15.23 * * *$ & $5.79 * *$ & $13.31 * * *$ & $11.34 * * *$ \\
\hline (p-value) & 0.01 & 0.00 & 0.00 & 0.00 & 0.00 & 0.00 & 0.00 & 0.00 & 0.00 & 0.02 & 0.00 & 0.00 \\
\hline Sum of Coef. & $1.62 * *$ & $0.50 * * *$ & $0.89 * * *$ & $0.55^{* * *}$ & $1.62 * * *$ & $0.78^{* * *}$ & $1.56^{* * * *}$ & $0.25^{* * * *}$ & $1.11^{* * * *}$ & $0.16^{* *}$ & $0.94 * * *$ & $0.31 * * *$ \\
\hline$\overline{\chi^{2}(4): R^{D} \rightarrow \Delta D}$ & $12.91 * *$ & 5.12 & $9.55^{* *}$ & 4.68 & $12.66^{* * *}$ & 7.08 & 10.49 ** & $9.45^{*}$ & $11.23 * *$ & $12.30^{* * *}$ & $13.18^{* * *}$ & $11.71^{* *}$ \\
\hline (p-value) & 0.01 & 0.27 & 0.04 & 0.32 & 0.01 & 0.13 & 0.03 & 0.05 & 0.02 & 0.02 & 0.01 & 0.02 \\
\hline$\chi^{2}(1): R^{D} \rightarrow \Delta D$ & $6.80^{* * *}$ & 0.66 & $5.87 * *$ & 0.35 & 8.50 *** & 0.50 & 7.40 *** & 0.06 & $8.59 * * *$ & 1.12 & $7.03 * * *$ & $6.80 * *$ \\
\hline (p-value) & 0.00 & 0.42 & 0.02 & 0.55 & 0.00 & 0.48 & 0.00 & 0.80 & 0.00 & 0.29 & 0.00 & 0.01 \\
\hline Sum of Coef. & $-0.09 * * *$ & -0.01 & $-0.03 * *$ & -0.02 & $-0.05 * * *$ & -0.01 & $-0.04 * * *$ & -000 & $-0.04 * * *$ & -0.00 & $-0.04 * * *$ & $-0.02 * *$ \\
\hline
\end{tabular}


Table 6. Robustness Tests (cont.)

Panel B. Excluding United States

\begin{tabular}{|c|c|c|c|c|c|c|c|c|c|c|c|c|}
\hline & \multicolumn{2}{|c|}{$\begin{array}{l}\text { Legal } \\
\text { Origin }\end{array}$} & \multicolumn{2}{|c|}{ Investment Profile } & \multicolumn{2}{|c|}{$\begin{array}{c}\text { Earnings Management } \\
\text { Smoothing }\end{array}$} & \multicolumn{2}{|c|}{$\begin{array}{c}\text { Big } 5 \\
\text { Auditors Presence }\end{array}$} & \multicolumn{2}{|c|}{$\begin{array}{c}\text { Number of } \\
\text { Analysts }\end{array}$} & \multicolumn{2}{|c|}{$\begin{array}{c}\text { Institutional } \\
\text { Investors }\end{array}$} \\
\hline & $\begin{array}{c}\text { Common } \\
1\end{array}$ & $\begin{array}{c}\text { Civil } \\
2\end{array}$ & $\begin{array}{c}\text { Strong } \\
\mathbf{3}\end{array}$ & $\begin{array}{c}\text { Weak } \\
4\end{array}$ & $\begin{array}{c}\text { Low } \\
5\end{array}$ & $\begin{array}{c}\text { High } \\
6\end{array}$ & High & $\begin{array}{c}\text { Low } \\
8\end{array}$ & High & Low & High & Low \\
\hline \multicolumn{13}{|l|}{ Market Timing } \\
\hline$\chi^{2}(4): S \rightarrow R^{E}$ & 2.21 & $11.75^{* *}$ & $8.64 *$ & 10.58 ** & $12.45^{* *}$ & $12.63 * *$ & 4.51 & $15.76^{* * * *}$ & $8.55^{*}$ & $11.51 * *$ & 7.57 & $14.59 * * *$ \\
\hline (p-value) & 0.70 & 0.02 & 0.07 & 0.03 & 0.01 & 0.01 & 0.34 & 0.00 & 0.07 & 0.02 & 0.11 & 0.00 \\
\hline$\chi^{2}(1): S \rightarrow R^{E}$ & 0.42 & $9.30 * * *$ & $4.71 * *$ & $4.35^{* *}$ & $3.92 * *$ & $4.65^{* *}$ & $3.54 *$ & $5.89 * *$ & $6.01 * *$ & $5.60 * *$ & $4.01 * *$ & $10.32 * * *$ \\
\hline (p-value) & 52.00 & 0.00 & 0.03 & 0.03 & 0.04 & 0.03 & 0.06 & 0.02 & 0.01 & 0.02 & 0.04 & 0.00 \\
\hline Sum of Coef. & -0.35 & $-1.24 * * *$ & $-0.78 * *$ & $-1.08 * *$ & $-1.18 * *$ & $-0.85 * *$ & $-0.74 *$ & $-1.26 * *$ & $-0.87 * *$ & $-1.27 * *$ & $-0.69 * *$ & $-2.04 * * *$ \\
\hline$\chi^{2}(4): \Delta \mathrm{E} \rightarrow \mathrm{R}^{\mathrm{E}}$ & 2.54 & 2.74 & 5.12 & 2.66 & 3.88 & 7.34 & 4.18 & $8.65^{*}$ & 4.77 & 5.02 & 3.74 & 4.49 \\
\hline (p-value) & 0.63 & 0.60 & 0.28 & 0.62 & 0.42 & 0.12 & 0.38 & 0.07 & 0.31 & 0.28 & 0.44 & 0.34 \\
\hline$\chi^{2}(1): \Delta \mathrm{E} \rightarrow \mathrm{R}^{\mathrm{E}}$ & 0.25 & 0.46 & $4.53 * *$ & 0.72 & 1.65 & $3.56^{*}$ & $3.66^{*}$ & $5.74 * *$ & $3.98 * *$ & 1.94 & $3.51 *$ & 2.42 \\
\hline (p-value) & 0.62 & 0.50 & 0.03 & 0.40 & 0.20 & 0.06 & 0.06 & 0.02 & 0.04 & 0.16 & 0.06 & 0.12 \\
\hline Sum of Coef. & -0.01 & -0.01 & $-0.02 * *$ & -0.02 & 0.02 & $-0.03 *$ & $-0.02 *$ & $-0.08 * *$ & $-0.02 * *$ & -0.03 & $-0.02 *$ & -0.06 \\
\hline$\chi^{2}(4): \Delta \mathrm{D} \rightarrow \mathrm{R}^{\mathrm{D}}$ & 2.96 & 0.062 & 1.20 & 1.93 & 6.38 & 0.58 & 1.78 & 4.45 & 2.08 & 2.43 & 2.47 & 1.10 \\
\hline (p-value) & 0.56 & 0.96 & 0.88 & 0.75 & 0.17 & 0.97 & 0.78 & 0.35 & 0.72 & 0.66 & 0.65 & 0.89 \\
\hline$\chi^{2}(1): \Delta \mathrm{D} \rightarrow \mathrm{R}^{\mathrm{D}}$ & 0.45 & 0.00 & 0.25 & 0.09 & 0.01 & 0.12 & 0.03 & 1.64 & 0.04 & 1.68 & 0.00 & 0.34 \\
\hline (p-value) & 0.50 & 0.95 & 0.62 & 0.76 & 0.93 & 0.72 & 0.86 & 0.20 & 0.84 & 0.19 & 0.95 & 0.56 \\
\hline Sum of Coef. & 0.00 & 0.00 & 0.00 & -0.00 & -0.00 & 0.00 & -0.00 & 0.01 & -0.00 & 0.01 & 0.00 & 0.00 \\
\hline \multicolumn{13}{|c|}{ Pseudo Market Timing } \\
\hline$\chi^{2}(4): R^{E} \rightarrow S$ & 0.88 & 1.46 & 7.97* & 2.64 & 4.84 & 2.73 & 2.41 & 2.33 & 5.25 & $10.66^{* *}$ & 1.49 & 4.71 \\
\hline (p-value) & 0.93 & 0.83 & 0.09 & 0.62 & 0.30 & 0.60 & 0.66 & 0.68 & 0.26 & 0.03 & 0.83 & 0.32 \\
\hline$\chi^{2}(1): R^{E} \rightarrow S$ & 0.01 & 0.14 & $6.16 * *$ & 0.01 & 1.59 & 1.99 & 0.93 & 0.00 & 0.48 & 0.60 & 0.22 & 1.12 \\
\hline (p-value) & 0.93 & 0.71 & 0.01 & 0.93 & 0.21 & 0.16 & 0.33 & 0.96 & 0.49 & 0.44 & 0.64 & 0.29 \\
\hline Sum of Coef. & 0.00 & 0.00 & $0.01 * *$ & -0.00 & 0.00 & 0.00 & 0.00 & -0.00 & 0.00 & 0.00 & 0.00 & 0.00 \\
\hline$\chi^{2}(4): R^{E} \rightarrow \Delta E$ & $20.94 * * *$ & $18.51 * * *$ & $27.39 * * *$ & $30.76 * * *$ & $22.16^{* * * *}$ & $32.95 * * *$ & $32.16^{* * * *}$ & $15.27 * * *$ & $27.46^{* * * *}$ & $9.27 *$ & $27.64 * * *$ & $11.66^{* *}$ \\
\hline (p-value) & 0.00 & 0.00 & 0.00 & 0.00 & 0.00 & 0.00 & 0.00 & 0.00 & 0.00 & 0.05 & 0.00 & 0.02 \\
\hline$\chi^{2}(1): R^{E} \rightarrow \Delta E$ & $12.68 * * *$ & $16.07 * * *$ & $22.65 * * *$ & $22.71 * * *$ & $19.88 * * *$ & $24.96 * * *$ & $27.66 * * *$ & $11.27 * * *$ & $25.15 * * *$ & $5.51 * *$ & $22.63 * * *$ & $11.34 * * *$ \\
\hline (p-value) & 0.00 & 0.00 & 0.00 & 0.00 & 0.00 & 0.00 & 0.00 & 0.00 & 0.00 & 0.02 & 0.00 & 0.00 \\
\hline$\underline{\text { Sum of Coef. }}$ & $0.91 * * *$ & $0.50 * * *$ & $0.72 * * *$ & $0.55^{* * * *}$ & $1.21 * * *$ & $0.78^{* * * *}$ & $1.30^{* * *}$ & $0.25^{* * *}$ & $0.87 * * *$ & $0.27 * *$ & $0.77 * * *$ & $0.31 * * *$ \\
\hline$\chi^{2}(4): R^{D} \rightarrow \Delta D$ & 5.05 & 5.20 & 2.70 & 4.19 & 1.92 & 7.61 & 4.81 & $9.90^{* * *}$ & 5.05 & $11.97^{* *}$ & 4.85 & $10.76^{* *}$ \\
\hline (p-value) & 0.28 & 0.27 & 0.61 & 0.38 & 0.75 & 0.11 & 0.31 & 0.04 & 0.28 & 0.02 & 0.30 & 0.03 \\
\hline$\chi^{2}(1): R^{D} \rightarrow \Delta D$ & 1.04 & 0.47 & 0.31 & 0.92 & 1.05 & 0.33 & 1.66 & 0.01 & 2.31 & 0.08 & 0.69 & $6.55^{* *}$ \\
\hline (p-value) & 0.31 & 0.49 & 0.58 & 0.34 & 0.30 & 0.57 & 0.20 & 0.91 & 0.13 & 0.77 & 0.41 & 0.01 \\
\hline Sum of Coef. & -0.02 & -0.01 & -0.00 & -0.02 & -0.01 & -0.01 & -0.01 & -0.00 & -0.02 & -0.00 & -0.01 & $-0.02 * *$ \\
\hline
\end{tabular}


Table 6. Robustness Tests (cont.)

Panel C: Excluding Simultaneous International Offerings

\begin{tabular}{|c|c|c|c|c|c|c|c|c|c|c|c|c|}
\hline & \multicolumn{2}{|c|}{$\begin{array}{l}\text { Legal } \\
\text { Origin }\end{array}$} & \multicolumn{2}{|c|}{ Investment Profile } & \multicolumn{2}{|c|}{$\begin{array}{c}\text { Earnings Management } \\
\text { Smoothing }\end{array}$} & \multicolumn{2}{|c|}{$\begin{array}{c}\text { Big } 5 \\
\text { Auditors Presence }\end{array}$} & \multicolumn{2}{|c|}{$\begin{array}{c}\text { Number of } \\
\text { Analysts }\end{array}$} & \multicolumn{2}{|c|}{$\begin{array}{c}\text { Institutional } \\
\text { Investors }\end{array}$} \\
\hline & $\begin{array}{c}\text { Common } \\
1\end{array}$ & $\begin{array}{c}\text { Civil } \\
2\end{array}$ & $\begin{array}{c}\text { Strong } \\
\mathbf{3}\end{array}$ & $\begin{array}{c}\text { Weak } \\
4\end{array}$ & $\begin{array}{c}\text { Low } \\
5\end{array}$ & $\begin{array}{c}\text { High } \\
6\end{array}$ & $\begin{array}{c}\text { High } \\
7\end{array}$ & $\begin{array}{c}\text { Low } \\
8\end{array}$ & $\begin{array}{l}\text { High } \\
9\end{array}$ & $\begin{array}{c}\text { Low } \\
10\end{array}$ & $\begin{array}{c}\text { High } \\
11\end{array}$ & $\begin{array}{c}\text { Low } \\
12\end{array}$ \\
\hline \multicolumn{13}{|l|}{ Market Timing } \\
\hline$\chi^{2}(4): S \rightarrow R^{E}$ & 6.86 & $12.76^{* * *}$ & $8.42 *$ & $10.58^{* * *}$ & 7.07 & $10.69 * *$ & 5.04 & $11.64 * *$ & 4.52 & 11.19 ** & 5.29 & $12.71 * *$ \\
\hline (p-value) & 0.14 & 0.01 & 0.08 & 0.03 & 0.13 & 0.03 & 0.28 & 0.02 & 0.34 & 0.02 & 0.26 & 0.01 \\
\hline$\chi^{2}(1): S \rightarrow R^{E}$ & 0.17 & $12.14 * * *$ & $2.72 *$ & $5.31 * *$ & 1.14 & $5.89 * *$ & 2.69 & $6.46 * *$ & $3.85^{* *}$ & $6.88^{* * *}$ & $4.33 * *$ & $6.92 * * *$ \\
\hline (p-value) & 0.68 & 0.00 & 0.09 & 0.02 & 0.29 & 0.02 & 0.10 & 0.01 & 0.04 & 0.00 & 0.04 & 0.00 \\
\hline Sum of Coef. & -0.17 & $-1.43 * * *$ & $-0.54 *$ & $-1.15 * *$ & -0.50 & $-0.98 * *$ & -0.55 & $-1.31 * *$ & $-0.65^{*}$ & $-1.36 * * *$ & $-0.63 * *$ & $-1.72 * * *$ \\
\hline$\chi^{2}(4): \Delta E \rightarrow R^{E}$ & 1.89 & 5.62 & 5.83 & 3.02 & 5.10 & $11.25^{* *}$ & 6.46 & $10.15^{* *}$ & 4.44 & 6.55 & 3.92 & 5.24 \\
\hline (p-value) & 0.76 & 0.23 & 0.21 & 0.55 & 0.28 & 0.02 & 0.17 & 0.04 & 0.35 & 0.16 & 0.42 & 0.26 \\
\hline$\chi^{2}(1): \Delta \mathrm{E} \rightarrow \mathrm{R}^{\mathrm{E}}$ & 0.95 & 0.60 & $5.07 * *$ & 0.99 & $3.07 *$ & $3.29 *$ & $5.51 * *$ & $5.24 * *$ & $3.52^{*}$ & 2.34 & $3.63^{*}$ & 2.37 \\
\hline (p-value) & 0.33 & 0.44 & 0.02 & 0.32 & 0.08 & 0.07 & 0.02 & 0.02 & 0.06 & 0.13 & 0.06 & 0.12 \\
\hline Sum of Coef. & -0.01 & -0.01 & $-0.02 * *$ & -0.02 & -0.01 & $-0.03 *$ & $-0.01 * *$ & $-0.10 * *$ & $-0.01 *$ & -0.04 & $-0.01 *$ & -0.09 \\
\hline$\chi^{2}(4): \Delta \mathrm{D} \rightarrow \mathrm{R}^{\mathrm{D}}$ & 3.26 & 0.69 & 4.08 & 1.49 & 2.78 & 0.58 & 3.06 & 4.28 & 3.39 & 3.04 & 2.82 & 4.16 \\
\hline (p-value) & 0.51 & 0.95 & 0.39 & 0.83 & 0.60 & 0.97 & 0.55 & 0.37 & 0.49 & 0.55 & 0.59 & 0.38 \\
\hline$\chi^{2}(1): \Delta \mathrm{D} \rightarrow \mathrm{R}^{\mathrm{D}}$ & 2.58 & 0.00 & $354^{*}$ & 0.10 & 2.21 & 0.09 & 2.35 & 1.59 & 2.71 & 2.36 & 2.30 & 0.39 \\
\hline (p-value) & 0.11 & 0.98 & 0.06 & 0.75 & 0.14 & 0.77 & 0.13 & 0.21 & 0.10 & 0.12 & 0.13 & 0.53 \\
\hline Sum of Coef. & 0.00 & 0.00 & $0.00 *$ & -0.00 & 0.00 & 0.00 & 0.00 & 0.01 & 0.00 & 0.01 & 0.00 & 0.00 \\
\hline \multicolumn{13}{|c|}{ Pseudo Market Timing } \\
\hline$\chi^{2}(4): R^{E} \rightarrow S$ & 2.13 & 2.43 & 4.80 & 2.45 & 6.82 & 5.18 & 0.33 & 6.70 & 5.98 & $16.97 * * *$ & 0.42 & 4.56 \\
\hline (p-value) & 0.71 & 0.66 & 0.31 & 0.65 & 0.15 & 0.27 & 0.99 & 0.15 & 0.20 & 0.00 & 0.98 & 0.34 \\
\hline$\chi^{2}(1): R^{E} \rightarrow S$ & 0.17 & 0.36 & 2.46 & 1.01 & 0.31 & 0.37 & 0.01 & 0.79 & 0.15 & 0.04 & 0.01 & 0.00 \\
\hline (p-value) & 0.68 & 0.55 & 0.12 & 0.31 & 0.58 & 0.54 & 0.93 & 0.37 & 0.70 & 0.84 & 0.91 & 0.96 \\
\hline Sum of Coef. & -0.00 & 0.00 & 0.00 & -0.00 & 0.00 & 0.00 & 0.00 & -0.00 & -0.00 & 0.00 & -0.00 & -0.00 \\
\hline$\chi^{2}(4): R^{E} \rightarrow \Delta E$ & $20.69 * * *$ & $15.99 * * *$ & $24.31 * * *$ & $26.06 * * *$ & $20.33 * * *$ & $29.88^{* * * *}$ & $30.30 * * *$ & $7.67^{*}$ & $20.53 * * *$ & 7.54 & $23.14 * * *$ & 7.02 \\
\hline (p-value) & 0.00 & 0.00 & 0.00 & 0.00 & 0.00 & 0.00 & 0.00 & 0.09 & 0.00 & 0.11 & 0.00 & 0.13 \\
\hline$\chi^{2}(1): \mathrm{R}^{\mathrm{E}} \rightarrow \Delta \mathrm{E}$ & $8.53^{* * *}$ & $12.97 * * *$ & $12.06 * * *$ & $16.87 * * *$ & $10.13^{* * *}$ & $21.88 * * *$ & $16.67 * * *$ & $5.05^{* *}$ & $12.53 * * *$ & $4.70^{* * *}$ & $14.11 * * *$ & $5.37 * *$ \\
\hline (p-value) & 0.00 & 0.00 & 0.00 & 0.00 & 0.00 & 0.00 & 0.00 & 0.02 & 0.00 & 0.03 & 0.00 & 0.02 \\
\hline Sum of Coef. & $1.49^{* * *}$ & $0.42 * * *$ & $0.75 * * *$ & $0.50^{* * * *}$ & $1.39 * * *$ & $0.68^{* * *}$ & $1.42 * * *$ & $0.15 * *$ & $0.87 * * *$ & $0.26 * *$ & $0.85^{* * *}$ & $0.18 * *$ \\
\hline$\chi^{2}(4): R^{D} \rightarrow \Delta D$ & $13.88 * * *$ & 4.35 & $12.78^{* *}$ & 5.17 & $11.58^{* *}$ & 6.37 & $13.02^{* *}$ & $8.32 *$ & $12.39^{* * *}$ & $9.51 * *$ & $14.22 * * *$ & $7.83^{*}$ \\
\hline (p-value) & 0.00 & 0.36 & 0.01 & 0.27 & 0.02 & 0.17 & 0.01 & 0.08 & 0.01 & 0.04 & 0.00 & 0.09 \\
\hline$\chi^{2}(1): \mathrm{R}^{\mathrm{D}} \rightarrow \Delta \mathrm{D}$ & $4.17 * *$ & 1.19 & $4.97 * *$ & 0.83 & $4.99 * *$ & 0.92 & $5.62 * *$ & 0.00 & $6.89^{* * *}$ & 0.20 & $4.80 * *$ & $6.00 * *$ \\
\hline (p-value) & 0.04 & 0.27 & 0.03 & 0.36 & 0.03 & 0.34 & 0.02 & 0.96 & 0.00 & 0.66 & 0.03 & 0.01 \\
\hline Sum of Coef. & $-0.06 * *$ & -0.02 & $-0.03 * *$ & -0.02 & $-0.04 * *$ & -0.01 & $-0.03 * *$ & -0.00 & $-0.04 * * *$ & -0.01 & $-0.04 * *$ & $-0.03 * *$ \\
\hline
\end{tabular}


Table 6. Robustness Tests (cont.)

Panel D. IPOs

\begin{tabular}{|c|c|c|c|c|c|c|c|c|c|c|c|c|}
\hline & \multicolumn{2}{|c|}{$\begin{array}{l}\text { Legal } \\
\text { Origin }\end{array}$} & \multicolumn{2}{|c|}{ Investment Profile } & \multicolumn{2}{|c|}{$\begin{array}{c}\text { Earnings Management } \\
\text { Smoothing }\end{array}$} & \multicolumn{2}{|c|}{$\begin{array}{c}\text { Big } 5 \\
\text { Auditors Presence }\end{array}$} & \multicolumn{2}{|c|}{$\begin{array}{c}\text { Number of } \\
\text { Analysts }\end{array}$} & \multicolumn{2}{|c|}{$\begin{array}{c}\text { Institutional } \\
\text { Investors }\end{array}$} \\
\hline & $\begin{array}{c}\text { Common } \\
1\end{array}$ & $\begin{array}{c}\text { Civil } \\
2\end{array}$ & $\begin{array}{l}\text { Strong } \\
\mathbf{3}\end{array}$ & $\begin{array}{c}\text { Weak } \\
4\end{array}$ & $\begin{array}{c}\text { Low } \\
5\end{array}$ & $\begin{array}{c}\text { High } \\
6\end{array}$ & $\begin{array}{c}\text { High } \\
7\end{array}$ & $\begin{array}{c}\text { Low } \\
8\end{array}$ & $\begin{array}{l}\text { High } \\
9\end{array}$ & $\begin{array}{c}\text { Low } \\
10\end{array}$ & $\begin{array}{c}\text { High } \\
11\end{array}$ & $\begin{array}{c}\text { Low } \\
12\end{array}$ \\
\hline \multicolumn{13}{|l|}{ Market Timing } \\
\hline$\chi^{2}(4): S \rightarrow R^{E}$ & 1.92 & 3.58 & 1.89 & 3.93 & $10.02^{* *}$ & 2.14 & 1.42 & $8.90 *$ & 1.09 & 7.11 & 3.98 & $9.15 *$ \\
\hline (p-value) & 0.75 & 0.47 & 0.76 & 0.42 & 0.04 & 0.71 & 0.84 & 0.06 & 0.90 & 0.13 & 0.41 & 0.06 \\
\hline$\chi^{2}(1): S \rightarrow R^{E}$ & 0.06 & 2.37 & 0.00 & 2.08 & 1.79 & 0.17 & 0.14 & $3.48 *$ & 0.40 & 1.94 & 0.01 & $6.96^{* * *}$ \\
\hline (p-value) & 0.81 & 0.12 & 0.97 & 0.15 & 0.18 & 0.68 & 0.71 & 0.06 & 0.53 & 0.16 & 0.93 & 0.00 \\
\hline$\underline{\text { Sum of Coef. }}$ & 0.10 & -0.73 & 0.01 & -0.82 & -0.59 & -0.17 & 0.12 & $-1.05^{*}$ & -0.21 & -0.81 & 0.03 & $-1.81 * * *$ \\
\hline$\overline{\chi^{2}(4): \Delta E \rightarrow R^{E}}$ & 2.76 & $10.08 * *$ & 6.72 & $10.68 * *$ & 5.60 & $9.01 *$ & 5.97 & $14.02 * * *$ & 5.31 & 6.86 & 6.06 & 1.43 \\
\hline (p-value) & 0.60 & 0.04 & 0.15 & 0.03 & 0.23 & 0.06 & 0.20 & 0.00 & 0.26 & 0.14 & 0.19 & 0.84 \\
\hline$\chi^{2}(1): \Delta \mathrm{E} \rightarrow \mathrm{R}^{\mathrm{E}}$ & 2.10 & $4.90 * *$ & $6.57 * *$ & $3.57 *$ & $4.96 * *$ & $4.88 * *$ & $5.61^{* *}$ & $8.08^{* * *}$ & $5.07 * *$ & $2.98^{*}$ & $5.91 * *$ & 0.46 \\
\hline (p-value) & 0.15 & 0.03 & 0.01 & 0.06 & 0.03 & 0.03 & 0.02 & 0.00 & 0.02 & 0.08 & 0.02 & 0.50 \\
\hline$\underline{\text { Sum of Coef. }}$ & -0.02 & $-0.06^{* *}$ & $-0.03 * *$ & $-0.06 *$ & -0.02 & $-0.05 * *$ & $-0.02 * *$ & $-0.14 * * *$ & $-0.02 * *$ & $-0.08 *$ & $-0.03 * *$ & -0.05 \\
\hline$\chi^{2}(4): \Delta \mathrm{D} \rightarrow \mathrm{R}^{\mathrm{D}}$ & 4.12 & 0.72 & 5.76 & 2.01 & 4.33 & 0.64 & 4.62 & 3.39 & 5.40 & 3.30 & 4.06 & 0.34 \\
\hline (p-value) & 0.39 & 0.95 & 0.22 & 0.73 & 0.36 & 0.96 & 0.33 & 0.49 & 0.25 & 0.51 & 0.40 & 0.99 \\
\hline$\chi^{2}(1): \Delta \mathrm{D} \rightarrow \mathrm{R}^{\mathrm{D}}$ & $3.51^{*}$ & 0.00 & $5.24 * *$ & 0.07 & $3.85 * *$ & 0.03 & $3.97 * *$ & 0.64 & $4.74 * *$ & 2.16 & $3.63^{*}$ & 0.11 \\
\hline (p-value) & 0.06 & 0.95 & 0.02 & 0.79 & 0.04 & 0.86 & 0.04 & 0.42 & 0.03 & 0.14 & 0.06 & 0.74 \\
\hline Sum of Coef. & $0.00 *$ & -0.00 & $0.00 * *$ & -0.00 & $0.00 *$ & 0.00 & $0.00 * *$ & 0.00 & $0.00 * *$ & 0.01 & $0.00^{*}$ & 0.00 \\
\hline \multicolumn{13}{|c|}{ Pseudo Market Timing } \\
\hline$\overline{\chi^{2}(4): R^{E} \rightarrow S}$ & 0.96 & $22.13 * * *$ & $13.61 * * *$ & 4.81 & 4.54 & $11.08^{* *}$ & 7.06 & 7.14 & 6.97 & $9.92 * *$ & $11.15^{* *}$ & $8.80 *$ \\
\hline (p-value) & 0.92 & 0.00 & 0.01 & 0.31 & 0.34 & 0.03 & 0.13 & 0.13 & 0.14 & 0.04 & 0.02 & 0.07 \\
\hline$\chi^{2}(1): R^{E} \rightarrow S$ & 0.46 & $5.56 * *$ & $8.71 * * *$ & 1.00 & $2.76^{*}$ & 2.36 & 1.01 & $3.79 *$ & 0.82 & $6.57 * *$ & $2.91 *$ & $2.78^{*}$ \\
\hline (p-value) & 0.50 & 0.02 & 0.00 & 0.32 & 0.09 & 0.12 & 0.32 & 0.05 & 0.36 & 0.01 & 0.09 & 0.09 \\
\hline Sum of Coef. & -0.00 & $0.01 * *$ & $0.01 * * *$ & 0.00 & $0.01 *$ & 0.01 & 0.00 & $0.01 *$ & 0.00 & $0.01 * *$ & $0.01 *$ & $0.01 *$ \\
\hline$\chi^{2}(4): R^{E} \rightarrow \Delta E$ & 7.46 & $14.43 * * *$ & $13.30 * * *$ & $22.74 * * *$ & $10.35^{* * *}$ & $16.89^{* * *}$ & $12.95^{* *}$ & $10.06^{* *}$ & $10.95^{* *}$ & 6.42 & $10.83 * *$ & 5.29 \\
\hline (p-value) & 0.11 & 0.00 & 0.00 & 0.00 & 0.04 & 0.00 & 0.01 & 0.04 & 0.03 & 0.17 & 0.03 & 0.26 \\
\hline$\chi^{2}(1): R^{E} \rightarrow \Delta E$ & $3.20^{*}$ & $10.01 * * *$ & $7.32 * * *$ & $13.55^{* * *}$ & $5.28 * *$ & $11.94 * * *$ & $8.64 * * *$ & $7.00^{* * *}$ & $8.59^{* * *}$ & 1.84 & $7.43^{* * *}$ & $4.81 * *$ \\
\hline (p-value) & 0.07 & 0.00 & 0.00 & 0.00 & 0.02 & 0.00 & 0.00 & 0.00 & 0.00 & 0.18 & 0.00 & 0.03 \\
\hline$\underline{\text { Sum of Coef. }}$ & $0.62 *$ & $0.28 * * *$ & $0.43 * * *$ & $0.32 * * *$ & $0.75^{* *}$ & $0.36 * * *$ & $0.78 * * *$ & $0.15 * * *$ & $0.52^{* * *}$ & 0.10 & $0.41^{* * *}$ & $0.18^{* *}$ \\
\hline$\overline{\chi 2}(4): \mathrm{R}^{\mathrm{D}} \rightarrow \Delta \mathrm{D}$ & $16.81 * * *$ & 6.69 & $8.59^{*}$ & 6.42 & $13.16^{* *}$ & 6.43 & $11.85^{* *}$ & $8.37 *$ & $10.97^{* *}$ & $11.33^{* *}$ & $12.71 * *$ & $11.91^{* *}$ \\
\hline (p-value) & 0.00 & 0.15 & 0.07 & 0.17 & 0.01 & 0.17 & 0.02 & 0.08 & 0.03 & 0.02 & 0.01 & 0.02 \\
\hline$\chi^{2}(1): R^{D} \rightarrow \Delta D$ & $7.06^{* * *}$ & 0.55 & $5.30 * *$ & 1.35 & $8.17 * * *$ & 0.32 & $7.15^{* * *}$ & 0.01 & $8.11^{* * *}$ & 0.38 & $6.21^{* *}$ & $6.16^{* *}$ \\
\hline (p-value) & 0.00 & 0.46 & 0.02 & 0.25 & 0.00 & 0.57 & 0.00 & 0.94 & 0.00 & 0.54 & 0.01 & 0.01 \\
\hline Sum of Coef. & $-0.11 * * *$ & -0.02 & $-0.04 * *$ & -0.03 & $-0.06 * * *$ & -0.01 & $-0.05 * * *$ & -0.00 & $-0.06 * * *$ & -0.01 & $-0.05^{* *}$ & $-0.03 * *$ \\
\hline
\end{tabular}


Table 6. Robustness Tests (cont.)

Panel E. SEOs

\begin{tabular}{|c|c|c|c|c|c|c|c|c|c|c|c|c|}
\hline & \multicolumn{2}{|c|}{$\begin{array}{c}\text { Legal } \\
\text { Origin }\end{array}$} & \multicolumn{2}{|c|}{ Investment Profile } & \multicolumn{2}{|c|}{$\begin{array}{l}\text { Earnings Management } \\
\text { Smoothing }\end{array}$} & \multicolumn{2}{|c|}{$\begin{array}{c}\text { Big } 5 \\
\text { Auditors Presence }\end{array}$} & \multicolumn{2}{|c|}{$\begin{array}{c}\text { Number of } \\
\text { Analysts }\end{array}$} & \multicolumn{2}{|c|}{$\begin{array}{c}\text { Institutional } \\
\text { Investors }\end{array}$} \\
\hline & Common & Civil & Strong & Weak & Low & High & High & Low & High & Low & High & Low \\
\hline & 1 & 2 & $\mathbf{3}$ & 4 & 5 & 6 & 7 & 8 & 9 & 10 & 11 & 12 \\
\hline \multicolumn{13}{|l|}{ Market Timing } \\
\hline$\chi^{2}(4): S \rightarrow R^{E}$ & 4.28 & $9.51 * *$ & $14.24 * * *$ & $7.74 *$ & 5.21 & $12.86^{* *}$ & 6.49 & $12.35 * *$ & 7.08 & $15.59 * * *$ & $7.80 *$ & $11.28 * *$ \\
\hline (p-value) & 0.37 & 0.04 & 0.00 & 0.09 & 0.27 & 0.01 & 0.17 & 0.02 & 0.13 & 0.00 & 0.09 & 0.02 \\
\hline$\chi^{2}(1): S \rightarrow R^{E}$ & 0.46 & $6.34 * *$ & 2.44 & $3.61^{*}$ & $4.50 * *$ & 2.31 & $3.09 *$ & $7.46^{* * *}$ & $5.36^{* *}$ & $5.25^{* *}$ & $4.65^{* *}$ & $6.72 * * *$ \\
\hline (p-value) & 0.50 & 0.01 & 0.12 & 0.05 & 0.03 & 0.13 & 0.08 & 0.00 & 0.02 & 0.02 & 0.03 & 0.00 \\
\hline Sum of Coef. & -0.29 & $-1.07 * *$ & -0.52 & -1.03 & $-0.93 * *$ & -0.64 & $-0.60 *$ & $-1.48 * * *$ & $-0.78 * *$ & $-1.21 * *$ & $-0.67 * *$ & $-1.68 * *$ \\
\hline$\overline{\chi^{2}(4): \Delta E \rightarrow R^{E}}$ & 0.64 & 2.48 & 4.13 & 5.56 & 2.63 & 5.30 & 4.10 & 5.79 & 3.42 & 1.67 & 2.83 & 3.98 \\
\hline (p-value) & 0.96 & 0.65 & 0.39 & 0.23 & 0.62 & 0.26 & 0.39 & 0.22 & 0.49 & 0.80 & 0.59 & 0.41 \\
\hline$\chi^{2}(1): \Delta E \rightarrow R^{E}$ & 0.44 & 0.01 & 2.46 & 0.54 & 1.21 & $2.75^{*}$ & $3.14^{*}$ & $3.55^{*}$ & 2.31 & 0.56 & 1.98 & 2.41 \\
\hline (p-value) & 0.51 & 0.94 & 0.12 & 0.46 & 0.27 & 0.09 & 0.08 & 0.06 & 0.13 & 0.46 & 0.16 & 0.12 \\
\hline Sum of Coef. & -0.01 & -0.00 & -0.01 & -0.02 & -0.01 & $-0.03 *$ & $-0.01 *$ & $-0.11 *$ & -0.01 & -0.02 & -0.01 & -0.10 \\
\hline$\chi^{2}(4): \Delta \mathrm{D} \rightarrow \mathrm{R}^{\mathrm{D}}$ & 4.18 & 0.67 & 5.77 & 7.75 & 3.73 & 0.42 & 4.11 & 4.18 & 4.76 & 2.90 & 4.13 & 2.06 \\
\hline (p-value) & 0.38 & 0.96 & 0.22 & 0.10 & 0.44 & 0.98 & 0.39 & 0.38 & 0.31 & 0.57 & 0.39 & 0.73 \\
\hline$\chi^{2}(1): \Delta \mathrm{D} \rightarrow \mathrm{R}^{\mathrm{D}}$ & $3.59^{*}$ & 0.00 & 2.65 & 2.22 & $3.12 *$ & 0.05 & $3.39^{*}$ & 1.27 & $3.88 * *$ & 1.66 & $3.60^{*}$ & 0.32 \\
\hline (p-value) & 0.06 & 0.95 & 0.10 & 0.14 & 0.08 & 0.83 & 0.06 & 0.26 & 0.04 & 0.20 & 0.06 & 0.57 \\
\hline Sum of Coef. & $0.00^{*}$ & -0.00 & 0.00 & 0.00 & $0.00^{*}$ & 0.00 & $0.00^{*}$ & 0.01 & $0.00 * *$ & 0.01 & $0.00^{*}$ & 0.00 \\
\hline \multicolumn{13}{|c|}{ Pseudo Market Timing } \\
\hline$\chi^{2}(4): R^{E} \rightarrow S$ & 1.22 & 6.37 & $8.50 *$ & 5.97 & 7.76 & 2.64 & 5.77 & 5.87 & 3.09 & $11.85^{* * *}$ & 5.61 & 4.11 \\
\hline (p-value) & 0.87 & 0.17 & 0.08 & 0.20 & 0.10 & 0.62 & 0.22 & 0.21 & 0.54 & 0.02 & 0.23 & 0.39 \\
\hline$\chi^{2}(1): R^{E} \rightarrow S$ & 0.51 & 1.84 & $3.29 *$ & 2.65 & 2.68 & 0.09 & $3.80^{*}$ & 2.40 & 0.24 & 0.17 & 0.00 & 0.05 \\
\hline (p-value) & 0.48 & 0.18 & 0.07 & 0.10 & 0.10 & 0.76 & 0.05 & 0.12 & 0.62 & 0.68 & 0.96 & 0.82 \\
\hline Sum of Coef. & 0.00 & 0.00 & $0.01 *$ & -0.01 & 0.01 & 0.00 & $0.01 *$ & -0.01 & 0.00 & -0.00 & 0.00 & 0.00 \\
\hline$\chi^{2}(4): R^{E} \rightarrow \Delta E$ & $20.03 * * *$ & $14.13 * * *$ & $21.48^{* * *}$ & $14.74 * * *$ & $20.13 * * *$ & $26.68 * * *$ & $28.20 * * *$ & $9.70 * *$ & $19.88 * * *$ & 6.68 & $21.69 * * *$ & 7.26 \\
\hline (p-value) & 0.00 & 0.00 & 0.00 & 0.00 & 0.00 & 0.00 & 0.00 & 0.04 & 0.00 & 0.15 & 0.00 & 0.12 \\
\hline$\chi^{2}(1): R^{E} \rightarrow \Delta E$ & $7.59^{* * *}$ & $13.79 * * *$ & $12.14 * * *$ & $9.39 * * *$ & $8.96 * * *$ & $22.73 * * *$ & $13.64 * * *$ & $6.93^{* * *}$ & $10.50 * * *$ & $4.85^{* *}$ & $12.03 * * *$ & $6.21^{* *}$ \\
\hline (p-value) & 0.00 & 0.00 & 0.00 & 0.00 & 0.00 & 0.00 & 0.00 & 0.00 & 0.00 & 0.03 & 0.00 & 0.01 \\
\hline Sum of Coef. & $1.50^{* * *}$ & $0.36^{* * * *}$ & $0.77^{* * *}$ & $0.32 * * *$ & $1.28^{* * * *}$ & $0.60^{* * * *}$ & $1.21^{* * *}$ & $0.15^{* * *}$ & $0.77 * * *$ & $0.24 * *$ & $0.75^{* * *}$ & $0.19^{* *}$ \\
\hline$\chi^{2}(4): \mathrm{R}^{\mathrm{D}} \rightarrow \Delta \mathrm{D}$ & $16.72 * * *$ & 3.38 & $11.46^{* *}$ & 3.52 & $14.56^{* * *}$ & 4.88 & $11.28^{* *}$ & $12.10^{* *}$ & $11.37 * *$ & $9.80 * *$ & $13.40 * * *$ & 5.57 \\
\hline (p-value) & 0.00 & 0.50 & 0.02 & 0.47 & 0.00 & 0.30 & 0.02 & 0.02 & 0.02 & 0.04 & 0.00 & 0.23 \\
\hline$\chi^{2}(1): R^{D} \rightarrow \Delta D$ & $7.26^{* * *}$ & 0.78 & $5.92 * *$ & 0.53 & $7.83^{* * *}$ & 0.55 & $7.15^{* * *}$ & 0.14 & $8.46^{* * *}$ & 0.02 & $6.88^{* * *}$ & $4.32 * *$ \\
\hline (p-value) & 0.00 & 0.38 & 0.02 & 0.47 & 0.00 & 0.46 & 0.00 & 0.71 & 0.00 & 0.90 & 0.00 & 0.04 \\
\hline Sum of Coef. & $-0.08 * * *$ & -0.02 & $-0.03^{* *}$ & -0.02 & $-0.05 * * *$ & -0.01 & $-0.04 * * *$ & 0.01 & $-0.05 * * *$ & -0.00 & $-0.04 * * *$ & $-0.02 * *$ \\
\hline
\end{tabular}

